Aus der Klink für Hämatologie und Medizinische Onkologie

(Prof. Dr. med. L. Trümper)

der Medizinischen Fakultät der Universität Göttingen

\title{
Vergleichende Analysen von drei verschiedenen Burkitt-Lymphom-Zelllinien im CAM-Xenograft- Modell unter besonderer Berücksichtigung des Transkriptionsfaktors LEF1
}

\author{
INAUGURAL-DISSERTATION \\ zur Erlangung des Doktorgrades \\ der Medizinischen Fakultät der \\ Georg-August-Universität zu Göttingen
}

vorgelegt von

Alina Friederike Blumberg

aus Göttingen

Göttingen 2018 
Dekan: $\quad$ Prof. Dr. rer. nat. H. K. Kroemer

Referent: $\quad$ Prof. Dr. rer. nat. D. Kube

Korreferent: Prof. Dr. rer. nat. J. Wilting

Drittreferentin: Prof. Dr. med. M. Schön

Datum der mündlichen Prüfung: $\quad$ 17.10.2018 
Hiermit erkläre ich, die Dissertation mit dem Titel

"Vergleichende Analysen von drei verschiedenen Burkitt-Lymphom-Zelllinien im CAM-Xenograft-Modell unter besonderer Berücksichtigung des Transkriptionsfaktors LEF1"

eigenständig angefertigt und keine anderen als die von mir angegebenen Quellen und Hilfsmittel verwendet zu haben.

Göttingen, den

(Alina Friederike Blumberg) 


\section{Inhaltsverzeichnis}

Abbildungsverzeichnis ............................................................................. III

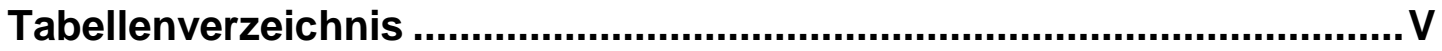

Abkürzungsverzeichnis .......................................................................... VI

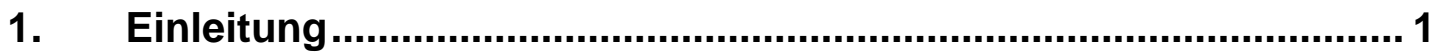

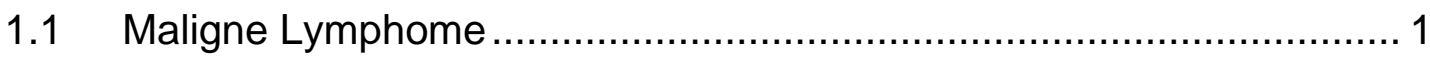

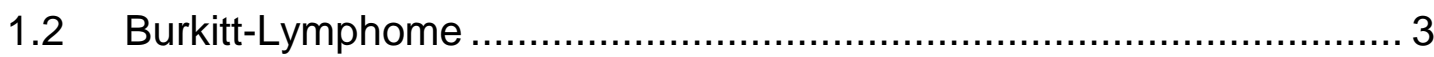

1.2.1 Der Transkriptionsfaktor LEF1 als molekularer Marker im Burkitt-

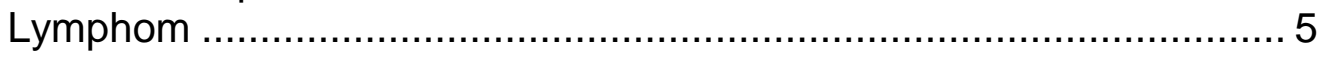

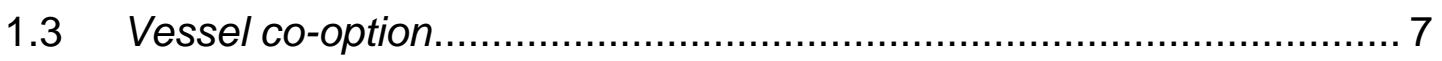

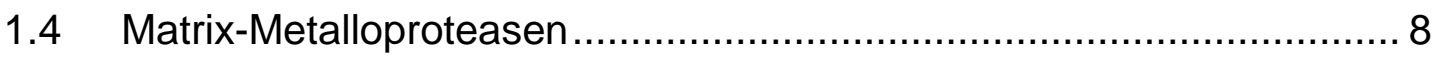

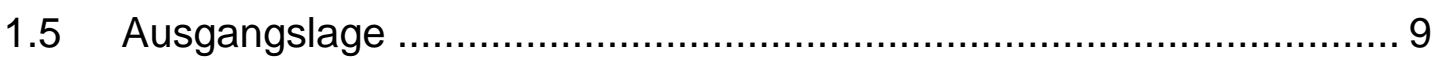

1.6 Zielsetzung .......................................................................... 10

2. Material und Methoden .................................................................11

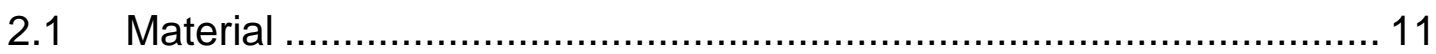

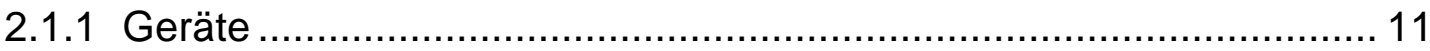

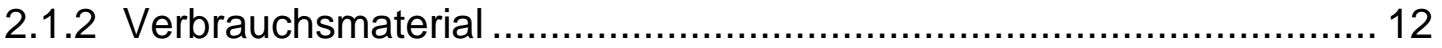

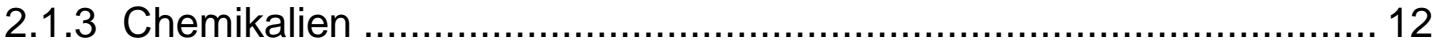

2.1.4 Puffer, Lösungen und Medien ...................................................... 14

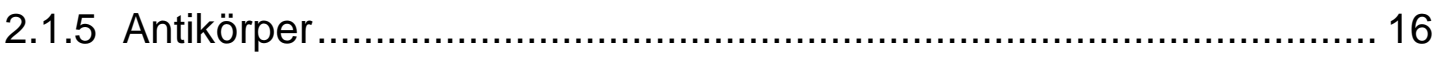

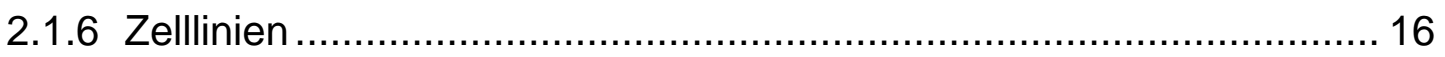

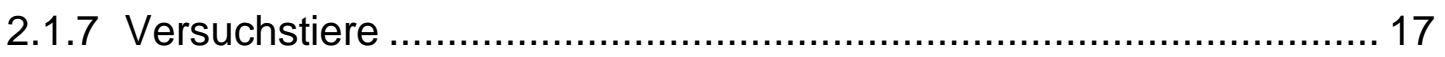

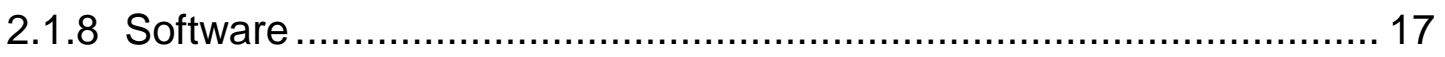

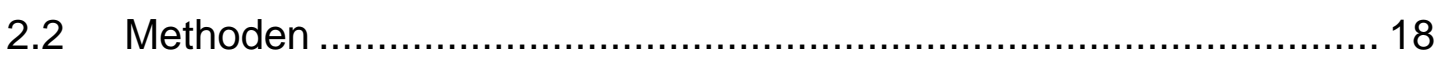

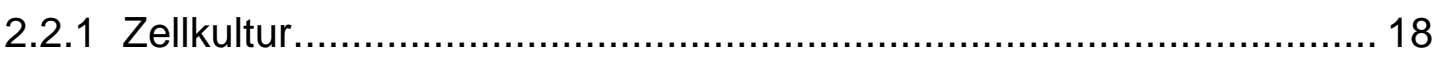

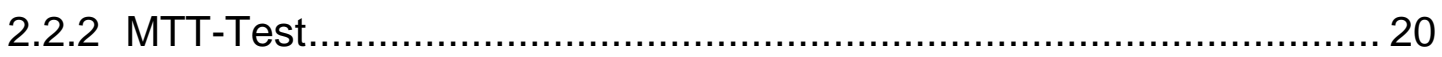

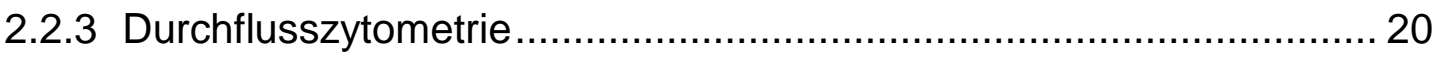




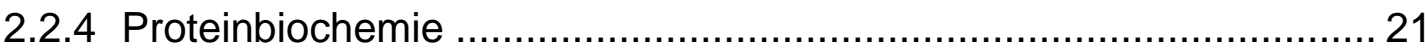

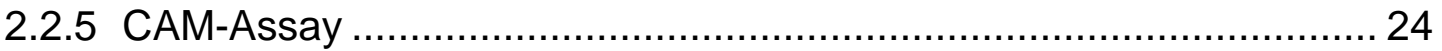

2.2.6 Histologische Methoden ......................................................... 25

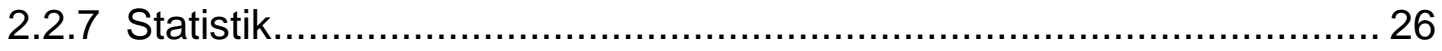

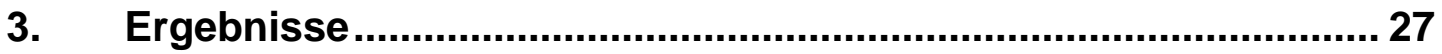

3.1 Der Einfluss von LEF1 auf die Tumormorphologie im CAM-XenograftModell verschiedener Burkitt-Lymphom-Zelllinien .......................... 27

3.1.1 LEF1-knockdown in CAM-Tumoren der Zelllinie BL-30.................. 27

3.1.2 LEF1-knockdown beeinflusst die Tumormorphologie in BL-41-CAMTumoren ................................................................................. 41

3.2 Vergleichende Analysen des Verhaltens der Burkitt-Lymphom-Zelllinien BL-2, BL-30 und BL-41 im CAM-Xenograft-Modell .......................... 52

3.2.1 MMP2 und MMP9 als mögliche Effektoren der Burkitt-LymphomHeterogenität im CAM-Modell

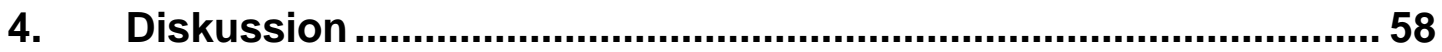

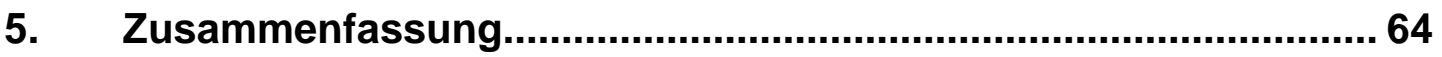

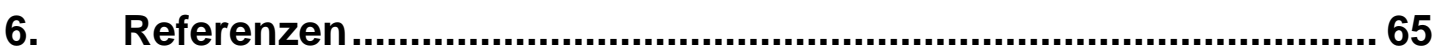




\section{Abbildungsverzeichnis}

Abbildung 3-1: Repräsentativer Nachweis der LEF1-Expression in BL-30Zellen.

Abbildung 3-2: Detektion der GFP-Expression in den BL-30-Zellen mittels Durchflusszytometrie und in CAM-Tumoren durch

Fluoreszenzmikroskopie.

Abbildung 3-3: Größenvergleich der BL-30-CAM-Tumoren (2 x $10^{6}$ applizierte Zellen).....

Abbildung 3-4: Anteil der hämorrhagischen Tumoren an der Tumorgesamtzahl (2x $10^{6}$ applizierte Zellen).

Abbildung 3-5: Übersicht über repräsentative mikroskopische Aufnahmen ausgewählter CAM-Tumoren.

Abbildung 3-6: Größenvergleich der BL-30-CAM-Tumoren ( 1 x $10^{6}$ applizierte Zellen).

Abbildung 3-7: Lichtmikroskopische Aufnahmen der BL-30-Tumoren (1 x $10^{6}$ applizierte Zellen).

Abbildung 3-8: Anteil der hämorrhagischen Tumoren an der Tumorgesamtzahl ( $1 \times 10^{6}$ applizierte Zellen).

Abbildung 3-9: Übersicht über BL-30-CAM-Tumoren ( 1 × $10^{6}$ applizierte Zellen).

Abbildung 3-10: LEF1-KD führt im BL-2-CAM-Modell zu geringerer Tumorzelldichte und vessel co-option.

Abbildung 3-11: Repräsentativer Nachweis der LEF1-Expression in BL-41Zellen.

Abbildung 3-12: Detektion der GFP-Expression in den BL-41-Zelllinien mittels Durchflusszytometrie und in CAM-Tumoren durch Fluoreszenzmikroskopie.

Abbildung 3-13: Größenvergleich der BL-41-CAM-Tumoren. 44

Abbildung 3-14: Repräsentative Auswahl der nativen BL-41-CAM-Tumoren.45

Abbildung 3-15: Repräsentative Auswahl von Tumorschnitten der vier BL-41-Subzelllinien.

Abbildung 3-16: Vessel co-option bei In-ovo-Lymphomen der BL-41 nach 
Abbildung 3-17: LEF1-exprimierende BL-41-Tumoren zeigen keine besondere Affinität zu Blutgefäßen.

Abbildung 3-18: BL-41-Tumoren weisen als morphologische Besonderheit regelmäßig eine verdickte CAM auf.

Abbildung 3-19: Eine verdickte CAM zeigt sich bei BL-41-Tumoren unabhängig von der applizierten Zellzahl..

Abbildung 3-20: Vergleich zweier Hellfeldaufnahmen der BL-41-Tumoren. . 51

Abbildung 3-21: Die Zelllinien BL-2, BL-30 und BL-41 unterschieden sich in vitro nicht signifikant in ihrer Proliferation.

Abbildung 3-22: Größenunterschiede der BL-41-, BL-2- und BL-30-CAMTumoren.

Abbildung 3-23: Repräsentative lichtmikroskopische Aufnahmen der extrahierten CAM-Tumor-Präparate.

Abbildung 3-24: Anteil der hämorrhagischen Tumoren an der Tumorgesamtzahl (n).

Abbildung 3-25: BL-41-, BL-2- und BL-30-CAM-Tumoren unterscheiden sich in ihrer mikroskopisch sichtbaren Zelldichte.

Abbildung 3-26: Repräsentatives Zymogramm konditionierter Medien von BL-30, BL-2 und BL-41.. 


\section{Tabellenverzeichnis}

Tabelle 2-1: Verwendete Geräte ......................................................... 11

Tabelle 2-2: Verwendete Verbrauchsmaterialien..................................... 12

Tabelle 2-3: Verwendete Chemikalien ................................................... 12

Tabelle 2-4: Verwendete Puffer, Lösungen und Ansätze .......................... 14

Tabelle 2-5: Verwendete Antikörper ............................................. 16

Tabelle 2-6: Verwendete Zelllinien ...................................................... 16

Tabelle 2-7: Mithilfe des pGIPZ-Vektors gentechnisch veränderte BurkittLymphom-Zelllinien.............................................................. 17

Tabelle 2-8: Verwendete Versuchstiere .......................................... 17

Tabelle 2-9: Verwendete Software ...................................................... 17

Tabelle 3-1: Übersicht über die BL-30-CAM-Tumoren (2x $10^{6}$ applizierte

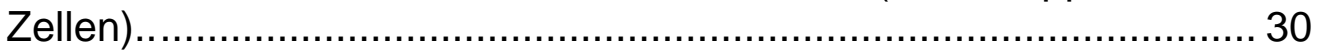

Tabelle 3-2: Übersicht über die BL-30-CAM-Tumoren $\left(1 \times 10^{6}\right.$ applizierte

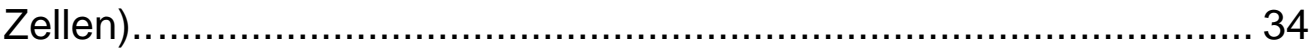

Tabelle 3-3: Zusammenfassung der BL-41-Tumoren........................... 44

Tabelle 3-4: Zusammenfassung der geernteten Tumoren. ...................... 53 


\section{Abkürzungsverzeichnis}

4-IPBA

ANOVA

APS

$B L$

BSA

CAM

CM

ctrl

DMSO

DNA

EBV

et al.

FACS

FCS

GAPDH

GFP

HE

HIV

HRP

HUVEC

ID3

$\lg$

$\mathrm{KD}$

LEF1

MMP

mRNA

MTT

$\mathrm{NHL}$

NK-Zellen

ns-control

$\mathrm{P} / \mathrm{S}$

PAGE

PBS

PFA

PMSF

RIPA

RNA

RT

SD

SDS

shRNA

shRNAmir 4-iodophenylboronic acid

analysis of variance

Ammoniumperoxodisulfat

Burkitt-Lymphom

bovine serum albumin

Chorion-Allantois-Membran

conditioned medium

control

Dimethylsulfoxid

deoxyribonucleic acid

Epstein-Barr-Virus

et alii

fluorescence-activated cell sorting

fetal calf serum

Glycerinaldehyd-3-phosphat-Dehydrogenase

green fluorescent protein

Hämatoxylin-Eosin

humanes Immundefizienz-Virus

horseradish peroxidase

human umbilical vein endothelial cells

inhibitor of DNA-binding 3

Immunglobulin

knockdown

lymphoid enhancer-binding factor-1

Matrix-Metalloprotease

messenger ribonucleic acid

3-(4,5-Dimethylthiazol-2-yl)-2,5-Diphenyltetrazoliumbromid Non-Hodgkin-Lymphom

natürliche Killerzellen

non-silencing control

Penicillin / Streptomycin

Polyacrylamidgelelektrophorese

phosphate-buffered saline

Paraformaldehyd

pheny/methylsulfonylfluorid

radio-immunoprecipitation assay

ribonucleic acid

Raumtemperatur

standard deviation

Sodiumdodecylsulfat

small hairpin ribonucleic acid

microRNA-adapted shRNA 
TBS

TBS-T

TCF

TEMED

üN

UTR

WHO

DLBCL tris-buffered saline

TBS-Tween

$T$ cell factor

$\mathrm{N}, \mathrm{N}, \mathrm{N}, \mathrm{N}$, -Tetramethyl-ethan-1,2-diamin über Nacht

untranslatierte Region

World Health Organization

diffuse large B-cell lymphoma 


\section{Einleitung}

\subsection{Maligne Lymphome}

Maligne Lymphome sind Tumoren des lymphatischen Systems. Sie kennzeichnen sich durch die unkontrollierte monoklonale Expansion von Lymphozyten und deren Vorläuferzellen (Kaiser und Neubauer 2013). Histologisch und historisch wird zwischen dem Hodgkin-Lymphom, das sich durch das Vorhandensein von charakteristischen großen mehrkernigen Sternberg-Reed-Zellen und einkernigen HodgkinZellen auszeichnet, und den Non-Hodgkin-Lymphomen (NHL) unterschieden (Lennert 1977). Die heterogene Gruppe der NHL macht etwa $75 \%$ der malignen Lymphome aus (Ackermann 2014).

Beim Hodgkin-Lymphom handelt es sich um ein Lymphom der B-Zellreihe, das mit einer Inzidenz von 3:100 000 Einwohnern pro Jahr auftritt und etwa ein Viertel der lymphatischen Malignome ausmacht (Piper 2007; Ackermann 2014).

Alle anderen lymphatischen Neoplasien werden als NHL zusammengefasst. Hierbei handelt es sich um eine heterogene Krankheitsgruppe, die nach der WHOKlassifikation in erster Linie nach ihrer Abstammung von B- oder T-Lymphozyten unterteilt werden und bei denen ferner danach differenziert wird, ob sie von früheren oder späteren (peripheren) Vorläuferzellen der Lymphopoese ausgehen (Jaffe 2009; Dürkop et al. 2011). Die B-Zell-Lymphome stellen dabei mit etwa $90 \%$ die weitaus häufigste Entität dar (Stein 2011). Die Gruppe der T-Zell-Lymphome macht dagegen nur etwa 5-10\% aller lymphatischen Tumoren aus, wobei dieser Anteil einer starken regionalen Abhängigkeit unterworfen ist (Stein 2011).

Auch wenn eigentlich durch die $\mathrm{WHO}$ (World Health Organization)-Klassifikation überholt, findet sich auch heute noch die Einteilung der Lymphome in niedrig- und hochmaligne durch die modifizierte Kiel-Klassifikation von 1992 (Lennert und Feller 1992). Lennert und seine Mitarbeiter beachteten hierbei vor allem mikroskopische und klinische Gesichtspunkte (Lennert et al. 1975). Die hochmalignen Lymphome bestanden vorwiegend aus „blastischen“ (unreiferen) Zellen, die aggressiven Lymphomen entsprachen und sich durch eine rasche klinische Progredienz auszeichneten (Lennert und Feller 1992; Tiemann und Trümper 2001). Niedrigma- 
ligne bzw. indolente Lymphome gingen überwiegend von „zystischen“ (reiferen) Zellen aus und wurden einem langsamer fortschreitenden Krankheitsverlauf zugeordnet (Lennert und Feller 1992; Tiemann und Trümper 2001). Da sich der Zusammenhang zwischen morphologischer Reife der Zellen und klinischer Aggressivität nicht für alle NHL zeigte und teilweise sehr irreführend ist, wird diese Einteilung zunehmend aufgegeben (Tiemann und Trümper 2001).

Nach dem 2013 veröffentlichten Bericht des Robert Koch-Instituts „Krebs in Deutschland 2009/2010" zählen die NHL mit einer Inzidenz von 11-16:100 000 Einwohnern pro Jahr und einem Anteil von 3,4 \% an allen Krebsneuerkrankungen Deutschlands zu den zehn häufigsten Malignomerkrankungen, wobei die Erkrankungsrate der NHL eine steigende Tendenz aufweist (Berger et al. 2013; Robert Koch-Institut 2013). Das mittlere Erkrankungsalter liegt für Männer bei 69 Jahren und für Frauen bei 71 Jahren, dabei steigt das Erkrankungsrisiko im Laufe des Lebens nahezu kontinuierlich an (Robert Koch-Institut 2013). Die 5-JahresÜberlebensrate aller NHL beträgt derzeit 67 \% (Robert Koch-Institut 2013).

Die klinischen Symptome der malignen Lymphome sind von der primären Lokalisation abhängig, können aber auch ganz fehlen. Im Vordergrund stehen schmerzlose derbe Lymphknotenschwellungen (Sedlacek 2013). Außerdem können unspezifische Symptome wie Müdigkeit, Fieber, Nachtschweiß und Gewichtsverlust auftreten (sog. B-Symptomatik) (Baumgärtel und Al-Abtah 2015). Einige Patienten entwickeln eine Hepato- und Splenomegalie, Anämie und Blutungsneigung (Baumgärtel und Al-Abtah 2015). Bei mediastinalem Befall können Atemwegsobstruktionen und eine obere Einflussstauung, bei intestinaler Manifestation Bauchschmerzen oder Harnwegsobstruktionen auffallen (Prinz 2012; Baumgärtel und Al-Abtah 2015). Die Diagnose wird in erster Linie durch Lymphknotenentnahme und anschließende histologische Untersuchung gestellt (Baumgärtel und Al-Abtah 2015). Als Risikofaktoren gelten Immunsuppression, z. B. nach Organtransplantationen oder bei Autoimmunerkrankungen, angeborene Immundefekte, Virusinfektionen mit dem Humanen Immundefizienz-Virus (HIV), dem Ebstein-Barr-Virus (EBV) oder dem Humanen Herpesvirus Typ 8 (Sedlacek 2013). Eine familiäre/genetische Prädisposition scheint ebenfalls eine Rolle zu spielen (Sedlacek 2013). 
Die jeweilige Therapie richtet sich nach dem Subtyp und dem Erkrankungsstadium. Maligne Lymphome verfügen über eine gute Strahlensensibilität und Polychemotherapieempfindlichkeit (Ammon et al. 2013). Des Weiteren stehen Immuntherapeutika, wie der Anti-CD20-Antikörper Rituximab, der sich gegen BZellen richtet, sowie Interferon- $\alpha$ zur Verfügung. Bei rezidivierenden Erkrankungen kommt zudem eine hämatopoetische Stammzelltransplantation in Betracht (Matzdorff und Fritze 2012; Sedlacek 2013). In der Regel sprechen besonders die schnell wachsenden, aggressiven Lymphome, wie auch das Burkitt-Lymphom, gut auf die Therapie an, wohingegen indolente lymphatische Neoplasien, wie die chronisch-lymphatische Leukämie selten heilbar sind (Matzdorff und Fritze 2012).

\subsection{Burkitt-Lymphome}

Beim Burkitt-Lymphom (BL) handelt es sich um ein aggressives schnell proliferierendes extranodales B-Zell-NHL (Jaffe 2009; Sedlacek 2013). Benannt ist es nach Denis P. Burkitt, einem Arzt, dem während seiner Arbeit in Äquatorialafrika in den 1950er Jahren gehäuft Kiefertumoren bei Kindern aufgefallen waren (Burkitt 1958). Man unterscheidet drei Formen, einen endemischen, einen sporadischen und einen Immundefekt-assoziierten Typ (Mosse und Weck 2010). Der 1958 von Burkitt beschriebene endemische Typ betrifft in erster Linie afrikanische Kinder zwischen fünf und zehn Jahren und äußert sich durch massive Kieferwinkellymphome und intestinale Lymphadenopathien (Piper 2007). Es handelt sich um den häufigsten pädiatrischen Tumor in afrikanischen Malariagebieten (Molyneux et al. 2012). In über $95 \%$ der Fälle sind die Tumorzellen positiv für das Epstein-BarrVirus (EBV) (Epstein et al. 1964; Kersten et al. 1998). Das sporadische BL macht beim Erwachsenen etwa 1-2\% aller Lymphome aus, bei Kindern dagegen $40 \%$ (Mosse und Weck 2010). Typischerweise ist beim sporadischen Typ lymphatisches Gewebe im terminalen lleum oder der Waldeyer-Rachenring betroffen, wohingegen eine Kieferbeteiligung äußerst selten ist (Piper 2007; Mosse und Weck 2010). Eine EBV-Assoziation findet sich hier bei $20-30 \%$ (Piper 2007). Bei HIVInfektion oder nach Organtransplantation spricht man von einem Immundefektassoziierten BL (Mosse und Weck 2010).

Das BL wird mit hochdosierten kombinierten Chemotherapeutika behandelt, die u.a. Methotrexat, Cyclophosphamid oder Doxorubicin enthalten (Hummel et al. 
2006; Sedlacek 2013). Außerdem kommt der monoklonale CD-20 Antikörper Rituximab erfolgreich zum Einsatz (Li und Chen 2012). Hierdurch wird eine komplette Remission bei etwa $90 \%$ der Kinder und $70 \%$ der Erwachsenen erreicht (Diviné et al. 2005; Hummel et al. 2006). In therapieresistenten Fällen kann zudem eine autologe hämatologische Stammzelltransplantation durchgeführt werden (Sedlacek 2013). Radiotherapie und operative Verkleinerung der Tumormasse hingegen sind i. d. R. nicht indiziert (Tiemann und Trümper 2001).

Das BL ist mit einer Verdopplungszeit von ca. $24 \mathrm{~h}$ der am schnellsten proliferierende Tumor des Menschen (Tiemann und Trümper 2001; Matzdorff und Fritze 2012; Molyneux et al. 2012). Außerdem handelt es sich um einen der ersten Tumoren, für den eine Onkogen-aktivierende Chromosomentranslokation festgestellt wurde (Zech et al. 1976; Molyneux et al. 2012). Als molekulares Charakteristikum des BL gilt eine Translokation des Protoonkogens MYC auf Chromosom 8 im Bereich q24 (Zech et al. 1976; Dalla-Favera et al. 1982; Molyneux et al. 2012; Sedlacek 2013). MYC ist ein universaler Verstärker aller in einer Zelle aktiven Gene (Nie et al. 2012). Es ist in vielen wachstumsfördernden Signaltransduktionswegen beteiligt und ein unmittelbar respondierendes Gen in den Signalketten vieler membranständiger Rezeptorkomplexe, wodurch MYC eine zentrale Rolle in Prozessen des Zellwachstums, der Proliferation, Stammzellregulation und Tumorgenese spielt (Kelly et al. 1983; Armelin et al. 1984; Dang 2012). Durch die Translokation gelangt MYC in 76-85\% der BL unter den Einfluss des auf Chromosom 14q32 gelegenen enhancers für die schwere H-Kette des Immunglobulin $(I g)$-Gens und wird dadurch konstitutiv exprimiert (Zech et al. 1976; Dalla-Favera et al. 1982; Lenoir et al. 1985; Sedlacek 2013). In 10-16 \% findet sich MYC in der Nähe der leichten Ig-Kette lambda auf Chromosom 22 ( $\mathrm{t}(8 ; 22)(\mathrm{q} 24 ; \mathrm{q} 11))$ und in $5-8 \%$ besteht die Translokation $\mathrm{t}(2 ; 8)(\mathrm{p} 11 ; \mathrm{q} 24)$, wodurch $M Y C$ sich in dem Bereich der leichten Ig-Kette kappa findet (Dalla-Favera et al. 1982; Lenoir et al. 1985; Sedlacek 2013). In seltenen Fällen kann auch eine MYC-Translokation in nicht-lgGenbereiche festgestellt werden (Bertrand et al. 2007).

Eine MYC-Translokation alleine reicht allerdings nicht aus, um ein BL entstehen zu lassen (Richter et al. 2012). So konnten mithilfe von DNA-Sequenzierungen von BL-Proben genetische Veränderungen an über 2000 Stellen detektiert werden 
(Richter et al. 2012). Love et al. (2012) stellten bei $34 \%$ (20 von 59), Richter et al. (2012) sogar bei $68 \%$ (36 von 53) der untersuchten BL eine Mutation im inhibitor of DNA-binding 3 (ID3) fest. Dagegen tragen nur $13 \%$ anderer B-Zell-Lymphome mit Ig-MYC-Translokation eine ID3-Mutation. Während ID3 in seiner Wildtyp-Form als Tumorsuppressor fungiert, bewirkt es über eine fehlende Hemmung von TCF( $T$ cell factor)-3 eine signifikante Hochregulierung des Zyklin D3 (Schmitz et al. 2014). Zyklin D3 wiederum vermittelt die G1- zu S-Phase-Transformation im Zellzyklus und wirkt damit proliferationsfördernd (Schmitz et al. 2014). Gain-offunction-Mutationen von TCF-3 finden sich bei $11 \%$ der BL und von Zyklin D3 bei 38 \% (Schmitz et al. 2012). Mutationen im ID3-Gen führen außerdem zu einer höheren Expression von bekannten MYC-Zielgenen (Love et al. 2012). Somit scheint die Kooperation zwischen Mutationen im ID3/TCF-3-Modul und Ig-MYCTranslokation ein wichtiges Kennzeichen der BL-Genese darzustellen, insbesondere, weil sie im nahe verwandten diffus großzelligen B-Zell-Lymphom (DLBCL) kaum vorkommen (Richter et al. 2012; Schmitz et al. 2014). Eine weiteres Charakteristikum des BL stellt die aberrante Expression des Transkriptionsfaktors lymphoid enhancer-binding factor-1 (LEF1) dar (Walther et al. 2013).

\subsubsection{Der Transkriptionsfaktor LEF1 als molekularer Marker im Burkitt- Lymphom}

Der lymphoid enhancer-binding factor-1 (LEF1) zählt zu der Familie der TCF/LEFTranskriptionsfaktoren (Travis et al. 1991; Reya et al. 2000). Das LEF1-Gen kodiert für ein dazugehöriges Protein, das unter anderem essentiell an der frühen Thymozytenreifung beteiligt ist (Steinke und Xue 2014). LEF1 wird nur in BProgenitor-Zellen und T-Lymphozyten, physiologischerweise aber nicht in reifen BZellen exprimiert (Travis et al. 1991; Reya et al. 2000; Walther et al. 2013).

Die Faktoren der TCF/LEF1-Familie vermitteln über die Assoziation mit $\beta$-Catenin im Zellkern eine transkriptionelle Antwort im kanonischen Wnt-Signalweg (Behrens et al. 1996; Huber et al. 1996; Brunner et al. 1997; Riese et al. 1997; Reya et al. 2000). Über diesen werden verschiedenste physiologische Mechanismen moduliert. Dazu gehören Proliferation, Apoptose und die Differenzierung von embryonalen und adulten Stammzellen (Arce et al. 2006; Holland et al. 2013). $\beta$-Catenin wirkt dabei als Schlüsselmediator: Bei Wnt-Stimulation oder bestimmten Genmuta- 
tionen wird $\beta$-Catenin im Zytosol stabilisiert und über Ran/Importin in den Nukleolus verlagert (Behrens et al. 1996; Huber et al. 1996; Reya et al. 2000). Dort bindet es an TCF/LEF1, wodurch Zelltyp-abhängig verschiedene Zielgene aktiviert werden (Jamieson et al. 2014; Scarpa und Ninfali 2015). Dies kann auch zur Aktivierung von Protoonkogenen wie MYC führen ( $\mathrm{He}$ et al. 1998; Barker et al. 2000). In Verbindung mit $\beta$-Catenin kann LEF1 Zellproliferation und Tumorzellinvasion regulieren ( $\mathrm{Li}$ et al. 2009). Der nukleare Import und die folgende B-Catenin Akkumulation korreliert außerdem positiv mit dem klinischen Grad vieler onkologischer Erkrankungen (Jamieson et al. 2014).

Globale Genexpressionsprofile von Patientenproben durch Hummel et al. (2006) führten zu der molekularen Definition des BL mit LEF1 als Signaturgen. In der gezielten Untersuchung von LEF1 in B-Zell-Lymphomen durch Walther et al. (2013) exprimierten 15 von 18 Patienten mit BL das LEF1-Gen sowie alle chronischen (6 von 6) und akuten B-Zell-Leukämien (6 von 6). Bei leukämischen Zellen überrascht dieses Ergebnis nicht, da sie aus Vorläufer-B-Zellen des Knochenmarks hervorgehen, die regelhaft LEF1-positiv sind und LEF1-abhängig proliferieren (Travis et al. 1991; Reya et al. 2000; Piper 2007). Mantelzelllymphome (0 von 5), Marginalzonenlymphome (0 von 6 ), follikuläre Lymphome (0 von 12), DLBCL (1 von 31) sowie reguläre Keimzentrums-B-Zellen aus Follikeln der Lymphknoten waren dagegen LEF1-negativ (Walther et al. 2013). Der Anteil von BL-Gewebe, das LEF1 exprimiert, ist damit außergewöhnlich hoch. Da physiologische Keimzentrums-B-Zellen LEF1-negativ sind, kann dessen Expression im BL als aberrant angesehen werden (Walther et al. 2013). In microarray-Analysen nach transientem LEF1-knockdown (KD) zeigte sich außerdem, dass LEF1 auch transkriptionell aktiv ist: Hier konnten neue auch mit Krebs assoziierte LEF1-Zielgene identifiziert werden (Walther et al. 2013).

LEF1 spielt auch in anderen malignen Neoplasien eine Rolle. So zeigte sich auch in Kolonkarzinom-Gewebe, verglichen mit umliegendem normalem Kolongewebe, eine signifikant erhöhte Konzentration von LEF1-mRNA und -Protein (Waterman 2004; Wang et al. 2013). In Untersuchungen durch Wang et al. (2013a+b) war eine erhöhte LEF1-Expression im Kolonkarzinom mit einer tieferen Tumorinfiltration, mehr Lymphknoten- und Fernmetastasen sowie einem kürzeren Gesamtüberleben 
assoziiert. Des Weiteren reduzierte ein LEF1-KD hier die Tumor-Zell-Viabilität, die Invasionskapazität und induzierte Apoptose (Wang et al. 2013). Als Zielgene von LEF1 konnten die Matrix-Metalloproteasen 2 und -9 identifiziert werden, deren Expression durch LEF1-KD gehemmt wurde (Wang et al. 2013). Im Maus-XenograftModell wurde durch den LEF1-KD das Tumorwachstum gehemmt (Wang et al. 2013). Auch im Endometriumkarzinom ist eine Überexpression von LEF1 im Vergleich zum physiologischen Endometrium beschrieben (Shelton et al. 2012). Im Prostatakarzinom stellt LEF1 einen Schlüsselregulator der Androgen-RezeptorExpression dar (Li et al. 2009). Auch hier gehen erhöhte LEF1-Level mit gesteigertem Tumorzellwachstum und verstärkter Tumorzellinvasion einher (Li et al. 2009).

\subsection{Vessel co-option}

Lange wurde angenommen, dass die meisten Tumoren und Metastasen als avaskuläre Zellansammlungen beginnen und nur durch die Induktion neuer Blutgefäße über die Größe von ein paar Millimetern hinaus wachsen können (Folkman 1971; Folkman 1990). Holash et al. (1999) stellten mit ihren Analysen diese bis dahin vorherrschende Meinung in Frage. Sie erkannten in Rattengliomen, dass maligne Zellen stattdessen schnell bereits existierende Gefäße kooptieren und erst danach beginnen, Angiogenese zu betreiben. Paradoxerweise geht von diesen Gefäßen daraufhin keine Angiogenese aus, vielmehr gehen sie im Verlauf vermutlich als Zeichen der Wirtsabwehr zu Grunde (Holash et al. 1999). Diese Gefäßregression hat zunächst die zentrale Nekrose des Tumors zur Folge (Holash et al. 1999). Durch die Hypoxie der Tumorzellen wird gleichzeitig am Tumorrand Angiogenese initiiert, wodurch der Tumor schließlich doch weiter versorgt wird und wächst (Shweiki et al. 1995; Holash et al. 1999). Eine zentrale Rolle wird in beiden Prozessen der Hochregulation des Angioprotein-2 und des vascular endothelial growth factor (VEGF) zugeschrieben (Holash et al. 1999). Diese sogenannte vessel co-option ist mittlerweile in vielen verschiedenen menschlichen Tumoren beschrieben, bevorzugt jedoch in gut durchblutetem Gewebe (Donnem et al. 2013). Auch im NHL ist diese Mikrozirkulation über präexistente Gefäße möglich und befähigt den Tumor auch ohne Neoangiogenese zum Wachstum und zur Metastasierung (Passalidou et al. 2003). 


\subsection{Matrix-Metalloproteasen}

Matrix-Metalloproteasen (MMPs) sind Zink-abhängige Endopeptidasen, die von der Zelle in die extrazelluläre Matrix abgegeben werden können und diese in ihrer aktiven Form abbauen (Alberts et al. 2011; Jacob und Prekeris 2015). Man unterscheidet nach ihrer Primärstruktur über 25 sekretierte oder sich an der Zellmembran befindliche Enzyme (Sternlicht und Werb 2001). MMPs spielen eine entscheidende Rolle bei den physiologischen Prozessen der Morphogenese, Wundheilung, Embryogenese und Angiogenese (Woessner 1991; Buddecke 2002).

Nach wie vor gilt der Schritt der Metastasierung als einer der entscheidenden Wendepunkte während einer Krebserkrankung, durch den sich die Lebenserwartung i. d. R. drastisch verringert (Jacob und Prekeris 2015). In vielen Studien wird angenommen, dass die Progression eines Tumors auf intrinsischen Eigenschaften der Tumorzellen beruht, wie deren Fähigkeit zu migrieren und zu invadieren (Jacob und Prekeris 2015). Abgesehen davon sind aber auch viele extrinsische Faktoren, z. B. Proteine der extrazellulären Matrix essentiell an der Regulation der Metastasierung beteiligt (Jacob und Prekeris 2015). Mindestens 14 der bekannten MMPs sind in der Tumorentwicklung und -progression beschrieben worden (Köhrmann et al. 2009). MMPs wirken in jedem Stadium der Tumorprogression mit, nicht nur wie ursprünglich angenommen, erst bei fortgeschrittener Erkrankung (Fingleton 2006). Bekannt sind in erster Linie die pro-tumorösen Funktionen; MMPs können aber auch anti-tumoröse Eigenschaften innehaben (Fingleton 2006).

Die ursprünglich beschriebene Tumor-assoziierte Rolle der MMPs lag in der Degradation der Basalmembran (Liotta et al. 1980). Der Verlust dieser Barrierefunktion ist ein wichtiger Schritt der Tumorzellinvasion und Metastasierung (Roskelley et al. 1995; Roskelley und Bissell 1995; Jacob und Prekeris 2015). AuBerdem scheinen MMPs Zelladhäsionsmoleküle zu degradieren, Wachstumsfaktoren freizusetzen und zu aktivieren sowie die Tumorangiogenese zu stimulieren (Polette et al. 2004; Jacob et al. 2013). Unter den MMPs stellen MMP2, -9 und -14 Schlüsselmediatoren in der Vermittlung verschiedenster Aspekte des Tumorwachstums und der Metastasierung dar (Chambers und Matrisian 1997; Egeblad und Werb 2002; Polette et al. 2004; Patel et al. 2009). Die Gelatinasen MMP2 und 
MMP9 werden mit der Degradation der Basalmembran in Verbindung gebracht (Martin und Matrisian 2007). Außerdem ist ihr Einfluss bereits beim Mamma- und Kolon-Karzinom beschrieben, bei letzterem auch insbesondere durch LEF1 reguliert (Damodharan et al. 2011; Jacob et al. 2013; Wang et al. 2013).

\subsection{Ausgangslage}

In Vorarbeiten der Arbeitsgruppe konnte gezeigt werden, dass der Transkriptionsfaktor LEF1 im Burkitt-Lymphom aberrant exprimiert wird (Walther et al. 2013). Außerdem konnten in microarray-Analysen nach transientem LEF1-knockdown (KD) neue Zielgene von LEF1 identifiziert werden (Walther et al. 2013). Durch Becker et al. (2012) wurde das Chorion-Allantois-Membran(CAM)-Xenograft-Modell erstmals für Analysen der Burkitt-Lymphom-Zelllinie BL-2 genutzt und Stefan Ueberdiek begann in seiner Promotion (2016) mit stabilen LEF1-KD-Zelllinien die bis dahin unbekannten In-ovo-Effekte von LEF1 in Bezug auf das Tumorwachstum zu untersuchen.

In den darauf aufbauenden, bisher unveröffentlichten Experimenten mit der Burkitt-Lymphom-Zelllinie BL-2 von Pia Wilming (2017) zeigten LEF1-KD-Tumoren weniger Einblutungen, als dies bei den Kontrollen der Fall war. Von den aberrant LEF1-exprimierenden CAM-Neoplasien zeigten 26,5\% Hämorrhagien, während dieser Anteil bei LEF1-KD Zellen nur 10,7\% betrug. Des Weiteren ließ sich bei den KD-Tumoren in der HE-Färbung eine Konzentration der Tumorzellen um einzelne Blutgefäße beobachten (sog. vessel co-option). Außerdem zeigte sich im Invitro-Migrationsassay mit der Endothelzelllinie HUVEC (human umbilical vein endothelial cells), dass die Endothelzellen durch den Anreiz der konditionierten Medien LEF1-exprimierender BL-2-Zelllinien stärker migrieren als mit konditionierten Medien der KD-Zelllinien. Dadurch liegt die Vermutung nahe, dass der Transkriptionsfaktor LEF1 eine Rolle in der Endothelzellpermeabilität von BurkittLymphomen im Xenograft-Modell spielen könnte.

Da die Effekte des LEF1-KD bisher lediglich bei einer BL-Zellinie untersucht wurden, galt es unter anderem festzustellen, ob diese auch bei anderen BL-ModellZellinien zu beobachten sind und die Daten auf Burkitt-Lymphome im Allgemeinen übertagen werden können. 


\subsection{Zielsetzung}

Ziel dieser Arbeit war es, die biologische Funktion von LEF1 im Burkitt-Lymphom zu analysieren. Hierzu sollte der in der Zelllinie BL-2 beobachtete Effekt von LEF1 auf die Tumorvaskularisierung im CAM-Xenograft-Modell auf dessen Reproduzierbarkeit in anderen BL-Zelllinien untersucht werden: Handelt es sich dabei um eine BL-2-spezifische Funktion von LEF1 oder kann dieser Effekt für BL im Allgemeinen angenommen werden? Um diese Frage zu beantworten, wurden zusätzlich zur Zelllinie BL-2-Subklone der Zelllinien BL-30 und BL-41 mit LEF1-KD und scrambled-shRNA-exprimierende Kontrollen auf die CAM von Hühnerembryonen aufgetragen. Unterschiede der Tumorentwicklung wurden durch deren Ausmessung und Histologie verglichen. Gleichzeitig sollte auch ein Vergleich des CAMWachstums der parenteralen Zelllinien sowie eine Analyse Matrix-degradierender Prozesse durchgeführt werden. 


\section{Material und Methoden}

\subsection{Material}

\subsubsection{Geräte}

Tabelle 2-1: Verwendete Geräte

\begin{tabular}{|c|c|}
\hline Gerät & Hersteller \\
\hline Accu Jet & Brand, Hamburg, Deutschland \\
\hline Brutschrank Cytoperm & Heraeus Instruments, Hanau, Deutschland \\
\hline Canoscan 5600F & Canon, Tokio, Japan \\
\hline Centrifuge $5415 \mathrm{D}$ & Eppendorf AG, Hamburg, Deutschland \\
\hline Centromat MO Schüttler & B. Braun AG, Melsungen, Deutschland \\
\hline Elektrophorese-Kammer und Wet-Blot-System & Bio-Rad GmbH, München, Deutschland \\
\hline FACScan Durchflusszytometer & Becton Dickinson, Heidelberg, Deutschland \\
\hline GFL 3005 Schüttelapparat mit Kreisbewegung & GFL, Burgwedel, Deutschland \\
\hline Glimmer-Sägeblatt 0,4 mm & Seipp, Langgöns, Deutschland \\
\hline Hera freeze $-80^{\circ} \mathrm{C}$ Gefrierschrank & Heraeus Instruments, Hanau, Deutschland \\
\hline Ikamag RCT Magnetrührer/Heizplatte & IKA, Staufen, Deutschland \\
\hline Inverses Durchlichtmikroskop Televal 31 & Carl Zeiss AG, Jena, Deutschland \\
\hline Kameraarm RLR & $\begin{array}{l}\text { Kaiser Fototechnik GmbH \& CO.KG, Buchen, } \\
\text { Deutschland }\end{array}$ \\
\hline Leica DFC290 & Leica Microsystems, Wetzlar, Deutschland \\
\hline Leica DM5000 B & Leica Microsystems, Wetzlar, Deutschland \\
\hline Leica M 125 & Leica Microsystems, Wetzlar, Deutschland \\
\hline Leica MZ16 FA & Leica Microsystems, Wetzlar, Deutschland \\
\hline Luminescent Image Analyzer LAS-4000 & Fujifilm, Düsseldorf , Deutschland \\
\hline Microflow Laminar Downflow Workstation & Bioquell, UK \\
\hline Microm HM 355S & MICROM, Walldorf, Deutschland \\
\hline Multifuge $3 \mathrm{~L}-\mathrm{R}$ & Heraeus Instruments, Hanau, Deutschland \\
\hline Neubauerzählkammer & $\begin{array}{l}\text { LO Laboroptik GmbH, Friedrichsdorf, Deutsch- } \\
\text { land }\end{array}$ \\
\hline NOVEX® DryEase $\AA$ Gel Drying System & Life Technologies, Carlsbad, USA \\
\hline Pinzette Dumont 5-Inox-E & Sigma, Osterode, Deutschland \\
\hline Pipetboy & Integra Biosciences, Fernwald, Deutschland \\
\hline Shandon Citadel 2000 Tissue Processor & Thermo Fisher Scientific Inc., Waltham, USA \\
\hline Shandon Histocentre $^{\mathrm{TM}} 3$ & Thermo Fisher Scientific Inc., Waltham, USA \\
\hline SunriseTM Mikrotiterplatten-Lesegerät & Tecan, Crailsheim, Deutschland \\
\hline Taumelrollmischer RM 5 & Hecht-Assistent, Sondheim, Deutschland \\
\hline Thermocycler 60 Wasserbad & Bio-med GmbH, Theres, Deutschland \\
\hline Tischzentrifuge $1-15 \mathrm{k}$ & Sigma, Osterode, Deutschland \\
\hline Transluminator TI3, UV-Lichtquelle & Biometra. Göttingen, Deutschland \\
\hline Ultra Low $-152^{\circ} \mathrm{C}$ Gefrierschrank & Sanyo, München, Deutschland \\
\hline Varistain ${ }^{\mathrm{TM}}$ 24-4 Automatic Slide Stainer & Thermo Fisher Scientific Inc., Waltham, USA \\
\hline Vortex Genie 2 & Schütt Labortechnik, Göttingen, Deutschland \\
\hline Waage L2200S & Sartorius, Göttingen, Deutschland \\
\hline
\end{tabular}




\begin{tabular}{|l|l|}
\hline $\begin{array}{l}\text { Walac } 1450 \text { MicroBeta® Trilux Szintillations- } \\
\text { und Lumineszenzzähler }\end{array}$ & PerkinElmer Inc., Waltham, USA \\
\hline Wasserbad & Köttermann Uetze/Hänigsen, Deutschland \\
\hline Zeiss Axis Kop 40 & Carl Zeiss AG, Jena, Deutschland \\
\hline
\end{tabular}

\subsubsection{Verbrauchsmaterial}

Tabelle 2-2: Verwendete Verbrauchsmaterialien

\begin{tabular}{|c|c|}
\hline Material & Hersteller \\
\hline 96- und 24-Well-Platte (Rund-/Flachboden) & Sarstedt, Nümbrecht, Deutschland \\
\hline Bijou Container $7 \mathrm{ml}$ & Thermo Fisher Scientific Inc., Waltham, USA \\
\hline Cellstar Tissue Culture Dishes & Greiner Bio-One, Kremsmünster, Österreich \\
\hline Deckgläser & Menzel, Braunchschweig, Deutschland \\
\hline Einbettformen aus Metall & Carl Roth GmbH, Karlsruhe, Deutschland \\
\hline Einfrierröhrchen & Nunc, Wiesbaden, Deutschland \\
\hline Falcon Röhrchen (15 ml, 50 ml) & Sarstedt, Nümbrecht, Deutschland \\
\hline Filter Tips $(10 \mu \mathrm{l}, 100 \mu \mathrm{l}, 1000 \mu \mathrm{l})$ & Sarstedt, Nümbrecht, Deutschland \\
\hline Filterpapier (Diethylaminoethyl-Zellulose) & Whatman GmbH, Dassel, Deutschland \\
\hline Filtropur S 0,2 & Sarstedt, Nümbrecht, Deutschland \\
\hline Leukosilk & BSN medical, Hamburg Deutschland \\
\hline Nitrozellulosemembran Hybond ${ }^{\mathrm{TM}}$-C Extra & Amersham Biosciences, Freiburg, Deutschland \\
\hline Novex® DryEase $\circledast$ Mini Cellophane & Life Technologies, Carlsbad, USA \\
\hline Objektträger Super Frost ${ }^{\circledR}$ & Carl Roth GmbH, Karlsruhe, Deutschland \\
\hline Pasteur-Plast Pipetten, steril & ratiolab®, Dreieich, Deutschland \\
\hline Perfusor® Syringe $50 \mathrm{ml}$ & Braun, Melsungen, Deutschland \\
\hline Polystyrene Round-Bottom Tube $5 \mathrm{ml}$ & BD Biosciences, New Jersey, USA \\
\hline Ready®Gel $10 \%$ Zymogramm (Gelatine) & BioRad, München, Deutschland \\
\hline Reaktionsgefäße $(0,5 \mathrm{ml}, 1,5 \mathrm{ml}, 2,0 \mathrm{ml})$ & Eppendorf, Hamburg, Deutschland \\
\hline Rotilabo®- Einbettkassetten & Carl Roth GmbH, Karlsruhe, Deutschland \\
\hline Serologische Pipetten (5 ml, $10 \mathrm{ml}, 25 \mathrm{ml})$ & Sarstedt, Nümbrecht, Deutschland \\
\hline $\begin{array}{l}\text { Zellkulturflaschen mit Belüftungskappe }\left(25 \mathrm{~cm}^{2} \text {, }\right. \\
\left.75 \mathrm{~cm}^{2}, 175 \mathrm{~cm}^{2}\right) \text { für Suspensionszellen }\end{array}$ & Sarstedt, Nümbrecht, Deutschland \\
\hline
\end{tabular}

\subsubsection{Chemikalien}

Tabelle 2-3: Verwendete Chemikalien

\begin{tabular}{|l|l|}
\hline \multicolumn{1}{|c|}{ Chemikalien } & \multicolumn{1}{c|}{ Hersteller } \\
\hline 4-IPBA (4-lodophenylboronic Acid) & Sigma-Aldrich, München, Deutschland \\
\cline { 2 - 2 } Acrylamid/Bisacrylamid 40 \% & BioRad, München, Deutschland \\
\hline Ammoniumpersulfat (APS) $\left(10 \%\right.$ in $\left.\mathrm{H}_{2} \mathrm{O}\right)$ & Sigma-Aldrich, München, Deutschland \\
\hline Auto MACS ${ }^{\text {IM }}$ Running Buffer & Miltenyi Biotec, Gladbach, Deutschland \\
\hline BD Matrigel ${ }^{\mathrm{IM}}$ Basement Membrane Matrix & BD Biosciences, New Jersey, USA \\
\hline Bovine Serum Albumin (BSA) & Serva, Heidelberg, Deutschland \\
\hline Bromphenolblau & Sigma-Aldrich, München, Deutschland \\
\hline Calcium-Chlorid $\left(\mathrm{CaCl}_{2}\right)$ & Merck KGaA, Darmstadt, Deutschland \\
\hline
\end{tabular}




\begin{tabular}{|c|c|}
\hline $\begin{array}{l}\text { Complete }{ }^{\mathrm{IM}} \text { Proteinaseninhibitor Cocktail } \\
\text { Tablets }\end{array}$ & Roche, Basel, Schweiz \\
\hline Coomassie Brilliant Blue G 250 pure & Serva, Heidelberg, Deutschland \\
\hline Dimethylsulfoxide (DMSO) & Sigma-Aldrich, Taufkirchen, Deutschland \\
\hline DPX Eindeckmedium für Histologie & Sigma-Aldrich, München, Deutschland \\
\hline Eosin B & Carl Roth GmbH, Karlsruhe, Deutschland \\
\hline Essigsäure $100 \%$ & Merck KGaA, Darmstadt, Deutschland \\
\hline Ethanol $99 \%$ & J.T. Baker, Griesheim, Deutschland \\
\hline Fetal Calf Serum (FCS) & Sigma-Aldrich, Taufkirchen, Deutschland \\
\hline Formaldehyd & Sigma-Aldrich, Taufkirchen, Deutschland \\
\hline Formaldehyd Lösung $37 \%$ & Merck KGaA, Darmstadt, Deutschland \\
\hline $\begin{array}{l}\text { Full Range Rainbow Molecular Weight Markers } \\
\text { RPN800E }\end{array}$ & GE Healthcare, München, Deutschland \\
\hline Giemsa Stammlösung & Carl Roth GmbH, Karlsruhe, Deutschland \\
\hline Glycin & Carl Roth GmbH, Karlsruhe, Deutschland \\
\hline Hämatoxylin & Carl Roth GmbH, Karlsruhe, Deutschland \\
\hline Isopropanol & Sigma-Aldrich, Taufkirchen, Deutschland \\
\hline Kalium-Chlorid (KCl) & Merck KGaA, Darmstadt, Deutschland \\
\hline Luminol & Sigma-Aldrich, Taufkirchen, Deutschland \\
\hline Mayer's Haemalaun Lösung & Merck KGaA, Darmstadt, Deutschland \\
\hline Methanol $99 \%$ & J.T. Baker, Deventer, Niederlande \\
\hline Methansäure & Sigma-Aldrich, München, Deutschland \\
\hline Methyl- ${ }^{3} \mathrm{H}-$ Thymidin & $\begin{array}{l}\text { GE Healthcare Buchler GmbH \& Co. KG, } \\
\text { Braunschweig, Deutschland }\end{array}$ \\
\hline Milchpulver & Carl Roth GmbH, Karlsruhe, Deutschland \\
\hline $\begin{array}{l}\text { MTT(3-[4,5-Dimethylthiazol-2-yl]-2,5- } \\
\text { diphenyltetrazolium Bromid) }\end{array}$ & Sigma-Aldrich, München, Deutschland \\
\hline Natrium-Chlorid $(\mathrm{NaCl})$ & Merck KGaA, Darmstadt, Deutschland \\
\hline Natrium-Desoxycholat & Merck KGaA, Darmstadt, Deutschland \\
\hline Natriumdodecylsulfat (SDS) & Merck KGaA, Darmstadt, Deutschland \\
\hline Paralplast Plus ${ }^{\circledR}$ & Sigma-Aldrich, Taufkirchen, Deutschland \\
\hline Penicillin/Streptomycin (P/S) & Sigma-Aldrich, Taufkirchen, Deutschland \\
\hline Phophat gepufferte Salzlösung (PBS) & Pan Biotech, Aidenbach, Deutschland \\
\hline Phos-Stop & Roche, Basel, Schweiz \\
\hline Pikrinsäure & Merck KGaA, Darmstadt, Deutschland \\
\hline PMSF & Sigma-Aldrich, Taufkirchen, Deutschland \\
\hline $\begin{array}{l}\text { Ponceau S- Lösung ( } 0,1 \% \text { Ponceau S in } 5 \% \\
\text { Essigsäure) }\end{array}$ & Sigma-Aldrich, Taufkirchen, Deutschland \\
\hline Puromycin & Invivo Gen, San Diego, USA \\
\hline ReBlot plus mild & Millipore, Schwalbach/Ts. Deutschland \\
\hline Rotiß-Histokit II & Carl Roth GmbH, Karlsruhe, Deutschland \\
\hline Roti®-Load (4 x Probenpuffer) & Carl Roth GmbH, Karlsruhe, Deutschland \\
\hline Roti®-Quant & Carl Roth GmbH, Karlsruhe, Deutschland \\
\hline RPMI-1640 mit L-Glutamin & Lonza Group Ltd., Basel, Schweiz \\
\hline Tetramethylethylenediamine (TEMED) & Sigma-Aldrich, Taufkirchen, Deutschland \\
\hline Trisbase Salzlösung (TBS) & Sigma-Aldrich, Taufkirchen, Deutschland \\
\hline Triton $\AA \mathrm{X}-100$ & Sigma-Aldrich, Taufkirchen, Deutschland \\
\hline
\end{tabular}




\begin{tabular}{|l|l|}
\hline Trypanblau 0.4 \% in PBS & $\begin{array}{l}\text { GIBCO BRL, Life Technologies, Eggenstein } \\
\text { Deutschland }\end{array}$ \\
\hline Tween-20 (T) & Merck KGaA, Darmstadt, Deutschland \\
\hline Wasser HPLC Grad & Merck KGaA, Darmstadt, Deutschland \\
\hline Xylol & Sigma-Aldrich, Taufkirchen, Deutschland \\
\hline Zymogramm Entwicklungspuffer (10x) & BioRad, München, Deutschland \\
\hline a-Thiolglycerol & Sigma-Aldrich, München, Deutschland \\
\hline
\end{tabular}

\subsubsection{Puffer, Lösungen und Medien}

Tabelle 2-4: Verwendete Puffer, Lösungen und Ansätze

\begin{tabular}{|c|c|}
\hline Puffer / Lösung / Ansatz & Zutaten \\
\hline Blockierlösung I & $5 \%$ BSA in TBS-T 0,1 \% \\
\hline Blockierlösung II & $5 \%$ Milchpulver in TBS-T 0,1\% \\
\hline Bouin-Fixanz (wässriges Bouin) & $\begin{array}{l}71 \% \text { Formaldehyd } 37 \% \\
24 \% \text { ml Pikrinsäure } \\
5 \% \text { Essigsäure } 100 \%\end{array}$ \\
\hline Einfriermedium & $\begin{array}{l}90 \%(v / v) \text { FCS } \\
10 \%(v / v) \text { DMSO }\end{array}$ \\
\hline Entfärbelösung & $\begin{array}{l}40 \% \text { Methanol } \\
10 \% \text { Essigsäure }\end{array}$ \\
\hline Färbelösung & $\begin{array}{l}40 \% \text { Methanol } \\
10 \% \text { Essigsäure } \\
0,5 \% \text { Coomassie Blau R-250 }\end{array}$ \\
\hline Fixierlösung & $\begin{array}{l}5 \% \text { Glycerin } \\
30 \% \text { Methanol }\end{array}$ \\
\hline Laufpuffer $(10 \mathrm{x})$ & $\begin{array}{l}25 \mathrm{mM} \text { Trisbase } \\
1,92 \mathrm{M} \text { Glycin } \\
1 \%(\mathrm{w} / \mathrm{v}) \text { SDS }\end{array}$ \\
\hline Lockelösung & $\begin{array}{l}152.45 \mathrm{mM} \mathrm{NaCl} \\
5.64 \mathrm{mM} \mathrm{KCl} \\
2.14 \mathrm{mM} \mathrm{CaCl}_{2}\end{array}$ \\
\hline Luminol-Lösung & $\begin{array}{l}100 \mathrm{mM} \text { Tris/HCl pH 8,8 } \\
2,5 \mathrm{mM} \text { Luminol } \\
4 \mathrm{mM} \text { 4-IPBA }\end{array}$ \\
\hline MACS-Puffer & $0,5 \%(w / v) B S A$ in PBS \\
\hline Mayers Hämalaun-Lösung & $\begin{array}{l}1 \mathrm{~g} \mathrm{Hämalaun} \\
1000 \mathrm{ml}_{\text {Aqua bidestilliert }} \\
0,2 \mathrm{~g} \mathrm{NaJO}_{3} \\
50 \mathrm{~g} \mathrm{Kalialaun} \\
50 \mathrm{~g} \text { Chloraldydrat } \mathrm{g} \text { Zitronensäure }\end{array}$ \\
\hline Paraformaldhyd $4 \%$ & $4 \%$ PFA in PBS \\
\hline Renaturierungslösung & $2,5 \%$ Triton-X-100 \\
\hline
\end{tabular}




\begin{tabular}{|c|c|}
\hline $\begin{array}{l}\text { RIPA (radio-immunoprecipitation assay)- } \\
\text { Lysepuffer }\end{array}$ & $\begin{array}{l}150 \mathrm{mM} \mathrm{NaCl} \\
50 \mathrm{mM} \mathrm{TrisHCl}(\mathrm{pH} 7,4) \\
1 \%(\mathrm{v} / \mathrm{v}) \mathrm{NP}-40 \text { (Igepal) } \\
0,25 \%(\mathrm{w} / \mathrm{v}) \mathrm{Natriumdeoxycholat} \\
0,1 \%(\mathrm{w} / \mathrm{v}) \mathrm{SDS} \\
\text { PMSF } 10 \mathrm{mg} / \mathrm{ml}(10 \mu \mathrm{l} / \mathrm{ml} \text { RIPA-Stocklösung; } \\
\text { frisch zugeben) } \\
\text { Complete } 20 \times(40 \mu \mathrm{l} / \mathrm{ml} \text {; frisch zugeben) } \\
\text { Phos-Stop } 20 \times(40 \mu \mathrm{l} / \mathrm{ml} \text {; frisch zugeben) }\end{array}$ \\
\hline Sammelgel (für ein Gel) & $\begin{array}{l}2,5 \mathrm{ml} \text { Sammelgel-Mix } \\
20 \mu \mathrm{l} \text { APS (10 \%) } \\
7,5 \mu \mathrm{l} \text { TEMED }\end{array}$ \\
\hline Sammelgel-Mix (5 \% Gel) & $\begin{array}{l}15 \%(\mathrm{v} / \mathrm{v}) \text { Acrylamid/Bis Solution (40\%) } \\
125 \mathrm{mM} \text { Tris Base } \mathrm{pH} 6.8 \\
0,1 \% \text { (w/v) SDS } \\
5 \mathrm{mM} \text { EDTA }\end{array}$ \\
\hline SDS Probenpuffer $(4 \mathrm{x})$ & $\begin{array}{l}500 \mu \mathrm{l} \text { Roti囚Load } 1(4 \mathrm{x}) \\
1 \% \text { gesättigte Bromphenolblau-Lösung }\end{array}$ \\
\hline SDS Zymographie Probenpuffer $(2 \mathrm{x})$ & $\begin{array}{l}62,5 \mathrm{mM} \text { Tris-HCL, pH } 6,8 \\
4 \% \text { SDS } \\
25 \% \text { Glycerol } \\
0,01 \% \text { Bromphenolblau }\end{array}$ \\
\hline TBS $(1 \mathrm{x})$ & $\begin{array}{l}20 \mathrm{mM} \text { Tris-Base pH 7,6 } \\
137 \mathrm{mM} \mathrm{NaCl} \mathrm{pH} \mathrm{7,6}\end{array}$ \\
\hline TBS-T & $\begin{array}{l}1 \times \text { TBS pH 7,6 } \\
0,1 \%(v / v) \text { Tween-20 }\end{array}$ \\
\hline Transferpuffer $(10 \mathrm{x})$ & $\begin{array}{l}25 \mathrm{mM} \text { Trisbase } \mathrm{pH} 8,3 \\
192 \mathrm{mM} \text { Glycin } \\
15 \%(\mathrm{v} / \mathrm{v}) \text { Methanol }\end{array}$ \\
\hline Trenngel $10 \%$ (für $1 \mathrm{Gel}$ ) & $\begin{array}{l}5 \mathrm{ml} \text { Trenngel-Mix } \\
40 \mu \mathrm{l} \text { APS (10 \%) } \\
15 \mu \mathrm{l} \text { TEMED }\end{array}$ \\
\hline Trenngel-Mix (10 \% Gel) & $\begin{array}{l}31.3 \% \text { (v/v) Acrylamid/Bis Solution (40 \%) } \\
332 \mathrm{mM} \text { Tris Base, } \mathrm{pH} 8.9 \\
3.33 \mathrm{mM} \text { EDTA }\end{array}$ \\
\hline Trypanblau-Lösung & $0,4 \%(w / v)$ Trypanblau in PBS \\
\hline Zellkultur-Medium I (für Wildtyp-Zelllinien) & $\begin{array}{l}\text { RPMI-1640 mit } 4 \text { mM L-Glutamin } \\
10 \% \text { FCS } \\
200 \mathrm{U} / \mathrm{ml} \text { Penicillin } \\
200 \mu \mathrm{g} / \mathrm{ml} \text { Streptomycin }\end{array}$ \\
\hline $\begin{array}{l}\text { Zellkultur-Medium II (für transduzierte Zellen/ } \\
\text { Puromycin-resistente Zellen) }\end{array}$ & $\begin{array}{l}\text { RPMI-1640 mit } 4 \mathrm{mM} \mathrm{L-Glutamin} \\
10 \% \text { FCS } \\
200 \mathrm{U} / \mathrm{ml} \text { Penicillin } \\
200 \mu \mathrm{g} / \mathrm{ml} \text { Streptomycin } \\
1 \mu \mathrm{g} / \mathrm{ml} \text { Puromycin }\end{array}$ \\
\hline MTT-Lösung I & $5 \mathrm{mg} / \mathrm{ml} \mathrm{MTT}$ in PBS \\
\hline
\end{tabular}




\begin{tabular}{|l|l|}
\hline MTT-Lösung II & $33 \%$ DMSO \\
& $5 \%$ Ameisensäure \\
& $62 \%$ Isopropanol \\
\hline
\end{tabular}

\subsubsection{Antikörper}

Tabelle 2-5: Verwendete Antikörper

\begin{tabular}{|l|l|l|}
\hline \multicolumn{1}{|c|}{ Antikörper } & \multicolumn{1}{|c|}{ Hersteller } & Verdünnung für Immunoblot \\
\hline $\begin{array}{l}\text { goat anti-mouse IgG-HRP } \\
\text { (D1609) }\end{array}$ & $\begin{array}{l}\text { Santa Cruz, Heidelberg, } \\
\text { Deutschland }\end{array}$ & $\begin{array}{l}1: 20000 \text { in } 5 \% \text { Milchpulver in } \\
\text { T-BST 0,1 \% }\end{array}$ \\
\hline $\begin{array}{l}\text { goat anti-rabbit IgG-HRP } \\
\text { (E1710) }\end{array}$ & $\begin{array}{l}\text { Santa Cruz, Heidelberg, } \\
\text { Deutschland }\end{array}$ & $\begin{array}{l}1: 2000 \text { in } 5 \% \text { BSA in T-BST } \\
0,1 \%\end{array}$ \\
\hline mouse anti-GAPDH (6C5) & Abcam, Cambridge, UK & $\begin{array}{l}1: 20000 \text { in } 5 \% \text { Milchpulver in } \\
\text { T-BST 0,1 \% }\end{array}$ \\
\hline rabbit anti-LEF1 (C18A7) & CellSignaling, Cambridge, UK & $\begin{array}{l}1: 1000 \text { in 5 \% BSA in T-BST } \\
0,1 \%\end{array}$ \\
\hline
\end{tabular}

\subsubsection{Zelllinien}

Tabelle 2-6: Verwendete Zelllinien

\begin{tabular}{|l|l|l|}
\hline \multicolumn{1}{|c|}{ Zelllinie } & \multicolumn{1}{|c|}{ Ursprung } & \multicolumn{1}{c|}{ Referenz } \\
\hline BL-2 & $\begin{array}{l}\text { B-Zelle, Burkitt-Lymphom, } \\
\text { EBV-negativ, Ursprung wurde } \\
\text { in folgendem Paper beschrie- } \\
\text { ben: Vockerodt et al. 2001 }\end{array}$ & Bertrand et al. 1981 \\
\hline BL-30 & $\begin{array}{l}\text { B-Zelle, Burkitt-Lymphom, } \\
\text { EBV-negativ, Ursprung wurde } \\
\text { in folgendem Paper beschrie- } \\
\text { ben: Vockerodt et al. 2001 }\end{array}$ & Calender et al. 1987 \\
\hline BL-41 & $\begin{array}{l}\text { B-Zelle, Burkitt-Lymphom, } \\
\text { EBV-negativ, Ursprung wurde } \\
\text { in folgendem Paper beschrie- } \\
\text { ben: Vockerodt et al. 2001 }\end{array}$ & \\
& & \\
\hline
\end{tabular}


Tabelle 2-7: Mithilfe des pGIPZ-Vektors gentechnisch veränderte Burkitt-LymphomZelllinien. Gezeigt sind die Zelllinien mit LEF1-knockdown und die entsprechenden KontrollZelllinien sowie die der Einfachheit halber im Folgenden verwendete Abkürzungen.

\begin{tabular}{|c|c|c|}
\hline Zelllinie & Verwendete Abkürzung & $\begin{array}{l}\text { Bindungsstelle der } \\
\text { shRNA an LEF1 }\end{array}$ \\
\hline BL-2 pGIPZ LEF1 shA GFP high & BL-2 LEF1 sh1 & $\begin{array}{l}\text { 3' UTR(Untranslatierte Re- } \\
\text { gion am 3' Ende) }\end{array}$ \\
\hline BL-2 pGIPZ LEF1 shE & BL-2 LEF1 sh2 & Exon 4 \\
\hline BL-2 pGIPZ ns-control1:2 & BL-2 ctrl 1 & --- \\
\hline BL-2 pGIPZ ns-control1:2* & BL-2 ctrl 2 & --- \\
\hline BL-30 pGIPZ LEF1 shA3 & BL-30 LEF1 sh1 & 3' UTR \\
\hline BL-30 pGIPZ LEF1 shA4 & BL-30 LEF1 sh2 & 3' UTR \\
\hline BL-30 pGIPZ LEF1 shE2* & BL-30 LEF1 sh3 & Exon 4 \\
\hline BL-30 pGIPZ ns-control3* & BL-30 ctrl 1 & --- \\
\hline BL-30 pGIPZ ns-control4* & BL-30 ctrl 2 & -- \\
\hline BL-41 pGIPZ LEF1 shE7* & BL-41 LEF1 sh1 & Exon 4 \\
\hline BL-41 pGIPZ ns-control1* & BL-41 ctrl 1 & --- \\
\hline BL-41 pGIPZ ns-control2* & BL-41 ctrl 2 & --- \\
\hline
\end{tabular}

\subsubsection{Versuchstiere}

Tabelle 2-8: Verwendete Versuchstiere

\begin{tabular}{|l|l|}
\hline \multicolumn{1}{|c|}{ Versuchstier } & \multicolumn{1}{|c|}{ Ursprung } \\
\hline $\begin{array}{l}\text { SPF (specific pathogen free) befruchtete wei- } \\
\text { Be Leghorn-Eier }\end{array}$ & $\begin{array}{l}\text { VALO BioMedia, Osterholz-Scharmbeck, } \\
\text { Deutschland }\end{array}$ \\
\hline
\end{tabular}

\subsubsection{Software}

\section{Tabelle 2-9: Verwendete Software}

\begin{tabular}{|l|l|}
\hline \multicolumn{1}{|c|}{ Software } & \multicolumn{1}{c|}{ Hersteller } \\
\hline Graph Pad Prism 5.04 for Windows & Graph Pad Software Inc., San Diego, USA \\
\hline IBM SPSS Statistics 24 & IBM Corporation, Armonk, USA \\
\hline IC Capture 2.0 & The Imaging Source, Bremen, Deutschland \\
\hline $\begin{array}{l}\text { Image J 1.48s (image processing and analysis } \\
\text { in Java) }\end{array}$ & $\begin{array}{l}\text { Rayne Rasband, National Institutes of Health, } \\
\text { Bethesda, USA }\end{array}$ \\
\hline Intrascience Imaging & Intrascience Limited, Dublin, Irland \\
\hline LAS v 3.8 Leica Application Suite & Leica Microsystems, Wetzlar, Deutschland \\
\hline Microbeta Windows Workstation 4.0 & PerkinElmer Inc., Waltham, USA \\
\hline Microsoft Word, Power Point, Excel (2010) & Microsoft, Redmont, USA \\
\hline NIS Elements F 2.20 & Nikon, Tokio, Japan \\
\hline
\end{tabular}




\subsection{Methoden}

\subsubsection{Zellkultur}

\subsubsection{Verwendete Zelllinien}

In dieser Arbeit wurden die Burkitt-Lymphom-Zelllinien BL-2, BL-30 und BL-41 verwendet. Die Suspensionszellen wurden mit einer Konzentration von 0,3 $1 \times 10^{6}$ Zellen pro $\mathrm{ml}$ Kulturmedium unter sterilen Bedingungen bei $37^{\circ} \mathrm{C}, 5 \%$ $\mathrm{CO}_{2}$ und $95 \%$ Luftfeuchtigkeit kultiviert. Für alle Versuche wurden Zellen mit einer Viabilität von mindestens $90 \%$ verwendet.

\section{Burkitt-Lymphom-Zelllinien mit stabilem LEF1-knockdown}

Zur funktionellen Charakterisierung des Transkriptionsfaktors LEF1 wurden die Burkitt-Lymphom-Zelllinien BL-2, BL-30 und BL-41 lentiviral transduziert. Es handelt sich um einen 2001 durch Kappes und Wu entwickelten replikationsinkompetenten HIV-1-basierten Lentivirus (Thermo Fisher Scientific Inc 2013).

Das pGIPZ-shRNAmir (microRNA-30 basierte short hairpin RNA)-Konstrukt enthält eine gegen LEF1 gerichtete shRNA-Sequenz, die stabil in das Lymphomgenom integriert wird. Bei der nächsten Transkription wird auch die antiLEF1-shRNA abgelesen. Die entstehende shRNA bindet dabei komplementär an die LEF1-mRNA (messenger RNA) und führt zu deren Degradation. Zur Selektion und Expressionskontrolle der shRNA enthält der pGIPZ-Vektor die Anlage einer Antibiotikumresistenz gegen Puromycin sowie zusätzlich eine green fluorescent protein (GFP)-Sequenz. Die Puromycinresistenz dient der Selektion der shRNAmir-exprimierenden Zellen. Die GFP-Expression erlaubt eine visuelle Quantifizierung der transduzierten Zellen via Durchflusszytometrie oder Immunfluoreszenzmikroskopie (siehe Kapitel 2.2.3.). Eine internal ribosomal entry site (IRES) erlaubt die Expression der GFP- und Puromycinresistenzgene als einzelnes Transkript.

Als Kontrollen diente eine non-silencing-shRNA-Sequenz (ns-control), die ins Genom integriert wird, aber deren shRNA keine komplementäre Ziel-mRNA im humanen Genom binden kann. Die Puromycinresistenz und Fluoreszenzeigenschaf- 
ten sind wie bei der LEF1-degradierenden Sequenz vorhanden, jedoch wird LEF1 regelhaft exprimiert.

Zu shRNA-Bindungsstellen und Zelllinien siehe 2.1.6.

\subsubsection{Zellkonzentrations- und Viabilitätsbestimmung}

Zur Konzentrationsbestimmung der Zellen wurde ein Aliquot eins zu eins mit einer 0,4 \%igen Trypanblau-Lösung vermischt und mithilfe einer Neubauerzählkammer gezählt. Die Konzentration der lebenden Zellen errechnet sich wie folgt: Konzentration $/ \mathrm{ml}=$ gezählte Zellanzahl $/ 200 \times 10^{6}$. Das Trypanblau dringt nur in geschädigte Zellwände toter Zellen ein und färbt diese im Gegensatz zu vitalen Zellen blau. Die Viabilität in Prozent ergibt sich aus dem Anteil der lebenden Zellen/Gesamtzellzahl.

\subsubsection{Gefrierkonservierung und Kultivierung eines gefrorenen Aliquots}

Die Suspensionszellen wurden maximal vier Wochen in Kultur gehalten. Zur Konservierung der kultivierten Zellen wurden diese bei $-150{ }^{\circ} \mathrm{C}$ eingefroren. Hierzu wurde zunächst die gewünschte Zellzahl bei $120 \mathrm{~g}$ und $21^{\circ} \mathrm{C} 7 \mathrm{~min}$ zentrifugiert, der Überstand verworfen und das Pellet in je $1 \mathrm{ml}$ Einfriermedium pro $5 \times 10^{6}$ Zellen resuspendiert. Darauffolgend wurde je $1 \mathrm{ml}$ in ein Einfrierröhrchen abgefüllt (à $5 \times 10^{6}$ Zellen) und zum schonenden Abkühlen $\left(1^{\circ} \mathrm{C} / \mathrm{min}\right)$ in Isopropanolboxen bei $-80^{\circ} \mathrm{C}$ zwischengelagert, bevor sie in $-150^{\circ} \mathrm{C}$ überführt wurden.

Um gefrorene Zellen in Kultur zu nehmen, wurden die entsprechenden Einfrierröhrchen im Wasserbad bei $37^{\circ} \mathrm{C}$ schnell aufgetaut, der Inhalt mit $9 \mathrm{ml}$ ZellkulturMedium verdünnt und ein Aliquot zur Konzentrationsbestimmung entnommen. Der Rest wurde bei $120 \mathrm{~g}$ und $21^{\circ} \mathrm{C} 7 \mathrm{~min}$ zentrifugiert. Das entstandene Zellpellet wurde mit Medium auf $0,5 \times 10^{6}$ Zellen / $\mathrm{ml}$ eingestellt.

\subsubsection{Herstellung konditionierter Medien}

Zur Herstellung konditionierter Medien (CM) wurden die Lymphom-Zelllinien in Zellkultur-Medium I mit einer Anfangskonzentration von $3 \times 10^{5} / \mathrm{ml}$ für 48 Stunden inkubiert. Der Überstand wurde steril filtriert $\left(0,2-\mu \mathrm{m}\right.$-Poren) und bei $4{ }^{\circ} \mathrm{C}$ maximal 4 Tage gelagert. 


\subsubsection{MTT-Test}

Mithilfe des 3-(4,5-Dimethylthiazol-2-yl)-2,5-diphenyltetrazoliumbromid-(MTT)Tests lässt sich über die Reduktion des gelblichen Farbstoffes MTT in ein blauviolettes Formazan die Glykolyserate der Zelle darstellen und somit indirekt auf die Zellviabilität und Zellproliferation schließen.

Die Zellen wurden bei $120 \mathrm{~g}, 21^{\circ} \mathrm{C} 7 \mathrm{~min}$ zentrifugiert, der Überstand abgenommen und das Zellpellet in Medium I auf eine Konzentration von $10^{5}$ Zellen / $\mathrm{ml}$ verdünnt. Nach $20 \mathrm{~h}$ Inkubation in der Zellkulturflasche bei $37{ }^{\circ} \mathrm{C}, 95 \%$ Luftfeuchtigkeit und $5 \% \mathrm{CO}_{2}$ wurden die Suspensionszellen in gleichen Teilen mit Medium I verdünnt und je $100 \mu \mathrm{l}$ der Verdünnung mit $10 \mu \mathrm{l}$ MTT I als Sextett in einer 96Well-Rundbodenplatte für vier Stunden inkubiert. Die Mikrotiterplatte wurde zentrifugiert $\left(160 \mathrm{~g}, 21^{\circ} \mathrm{C}, 10 \mathrm{~min}\right)$, der Überstand mit der Pipette abgenommen und $100 \mu \mathrm{l}$ MTT-Lösung II dazugegeben. Zellen und der je nach Glykolyserate reduzierte, nun violette Farbstoff wurden mithilfe eines Schüttelapparates gelöst und die optische Dichte bei $560 \mathrm{~nm}$, einem Referenzfilter von $720 \mathrm{~nm}$ gemessen und der Leerwert abgezogen. Je mehr Farbstoff reduziert wurde, desto höher die optische Dichte.

\subsubsection{Durchflusszytometrie}

Bei der Durchflusszytometrie handelt es sich um ein Laser-basiertes Verfahren zur Zellcharakterisierung in Bezug auf Form, Oberflächenbeschaffenheit und Fluoreszenzeigenschaften. In dieser Arbeit wurde sie zur Quantifizierung der GFPExpression der gentechnisch veränderten BL-Zellen und somit indirekt als Kontrolle für den pGIPZ-Vektor-vermittelten LEF1-KD verwendet. Hierzu wurden ca. $2 \times 10^{6}$ Zellen aus der Zellkulturflasche entnommen und in einem RundbodenRöhrchen bei $120 \mathrm{~g}$ und $21^{\circ} \mathrm{C} 7 \mathrm{~min}$ zentrifugiert. Nach Verwerfen des Überstandes wurden die Zellen in $1 \mathrm{ml}$ MACS-Puffer gelöst. Kurz vor der Messung wurden die Zellen im Vortexmischer durchmischt.

Während der Messung werden die angesaugten Zellen einzeln durch eine Flusskammer an einem Laserstrahl vorbeigeführt. Abhängig von Zellgröße und Granularität wird dabei ein Streulicht erzeugt, das mittels Detektoren eingefangen wird. In einem dargestellten Dot Plot können dann zellpopulationsspezifische Charakte- 
ristika erkannt werden. Außerdem kann über die Anregung mit blauem oder ultraviolettem Licht die Fluoreszenzeigenschaft, hier ausgelöst durch das GFP, bestimmt werden. Die Daten wurden durch die Software CellQuest ${ }^{\mathrm{TM}}$ (Becton Dickinson) analysiert.

\subsubsection{Proteinbiochemie}

\subsubsection{Zelllyse}

Zur Herstellung von Proteinlysaten wurde stets auf Eis gekühlt gearbeitet. Zunächst wurden $3 \times 10^{6}$ Zellen bei $120 \mathrm{~g}$ und $21^{\circ} \mathrm{C} 7 \mathrm{~min}$ sedimentiert und das Zellpellet mit $1 \mathrm{ml}$ kaltem PBS $\left(4^{\circ} \mathrm{C}\right)$ gewaschen. Es folgte erneutes Zentrifugieren bei $400 \mathrm{~g}$ und $4^{\circ} \mathrm{C} 5 \mathrm{~min}$. Jedes Zellpellet wurde in $100 \mu \mathrm{l}$ RIPA-Lösung gelöst und $30 \mathrm{~min}$ lysiert, danach bei $500 \mathrm{~g}$ und $4{ }^{\circ} \mathrm{C} 15 \mathrm{~min}$ zentrifugiert. Der proteinhaltige Überstand wurde abgenommen und die im Pellet befindlichen Zellreste verworfen.

\subsubsection{Proteinkonzentrationsbestimmung nach Bradford}

Die Bestimmung der Proteinkonzentration im Proteinlysat erfolgte nach der Bradford Methode mittels Photometrie (Bradford 1976). Um aus der später ermittelten Absorption Rückschlüsse auf die tatsächliche Proteinkonzentration der Proben ziehen zu können, wurde eine BSA (bovine serum albumin)Standardverdünnungsreihe $(0 \mu \mathrm{g} / \mathrm{ml}-100 \mu \mathrm{g} / \mathrm{ml})$ erstellt. Die Proteinlysate und die RIPA-Lösung als Leerwert wurden 1:80 mit $\mathrm{H}_{2} \mathrm{O}$ verdünnt und hiervon sowie von der Standardverdünnungsreihe je $50 \mu \mathrm{l}$ als Tripletts in eine 96-WellFlachboden-Mikrotiterplatte vorgelegt. Anschließend wurde auf jede Probe $200 \mu \mathrm{l}$ der Roti ${ }^{\circledR}$ Quant-Lösung (1 $\mathrm{x}$ ) gegeben und $5 \mathrm{~min}$ bei Raumtemperatur (RT) inkubiert. Die Messung der optischen Dichte erfolgte bei einer Wellenlänge von $595 \mathrm{~nm}$. Aus den Ergebnissen der Standardverdünnungsreihe wurde eine Eichgerade erstellt und anhand derer die Proteinkonzentration der Lysate ermittelt.

\subsubsection{Diskontinuierliche SDS-PAGE}

Proteine lassen sich über einem elektrischen Feld ihrer Größe nach separieren. In Sodiumdodecylsulfat (SDS) gelöste Proteine nehmen proportional zu ihrer Masse negative Ladungen des anionischen SDS auf und können dann in einer Polyacrylamidgelelektrophorese (PAGE) durch die unterschiedlich starken Ladun- 
gen aufgetrennt werden. Kleine und damit weniger negativ geladene Proteine wandern dabei schneller durch die Maschen des Polyacrylamidgels und finden sich weiter entfernt von der Auftragungsstelle als große.

Das Gel besteht aus zwei Phasen, einem 5 \%igen Sammelgel, in dem die Probe aufkonzentriert wird, und einem $10 \%$ igen Trenngel, in dem die eigentliche Separation stattfindet. Pro Trenngel wurden zu $5 \mathrm{ml}$ Trenngelmix $40 \mu \mathrm{l}$ APS (10\%) und $15 \mu$ TEMED gegeben, in die Gelhalterung gegossen und zur Glättung der Oberfläche mit Isopropanol bedeckt. Nach Polymerisation und Abgießen des Isopropanols wurde darauf das Sammelgel (2,5 ml Sammelgelmix, $20 \mu \mathrm{l} 10$ \%iges APS, 7,5 $\mu$ I TEMED) gegossen. Durch das Einstecken eines Kammes entstanden einzelne Fächer für die Proben.

Für eine Probe wurden zunächst $20 \mu \mathrm{g}$ Protein in RIPA-Lysepuffer auf $15 \mu \mathrm{l}$ verdünnt und mit $5 \mu \mathrm{l} 4 \times$ Roti $^{\Theta}$-Load 5 min bei $95^{\circ} \mathrm{C}$ denaturiert, um dann nach $\mathrm{Ab}$ kühlung auf Eis in eine Tasche des Gels aufgetragen zu werden. Bei $20 \mathrm{~mA}$ liefen die Proben etwa 20 min bis zum Erreichen der Trenngelgrenze, worauf die Stromstärke auf $40 \mathrm{~mA}$ erhöht wurde, bis die Proteinbande das Ende des Gels erreichte. Zur Detektion der Proteingröße wurde der Fullrange Rainbow ${ }^{\text {TM }}$ Marker verwendet.

\subsubsection{Immunoblot}

Der Transfer der aufgetrennten Proteine von dem Polyacrylamidgel auf eine Nitrozellulosemembran, auch Western-Blot genannt, erfolgte als Nass-Blot durch eine senkrecht zum Gel angelegte Spannung von $100 \mathrm{~V}$ über $1 \mathrm{~h}$ bei $4^{\circ} \mathrm{C}$. Die Blotkammer wurde wie folgt aufgebaut, wobei alle Komponenten in Transferpuffer getränkt waren: Kathode(-), dünner Schwamm, zwei whatmanpaper, Polyacrylamidgel, Nitrozellulosemembran, zwei whatmanpaper, dünner Schwamm, Anode(+). Nach dem Blotten wurde die Gleichmäßigkeit der Proteinbeladung durch eine reversible Färbung mit dem Azofarbstoff Ponceau $S$ überprüft und fotografisch dokumentiert, anschließend durch Schwenken in TBS-T 0,1\% wieder entfernt. Zum Blockieren unspezifischer Bindungen schloss sich ein einstündiges Blocken in $5 \%$ Milch in TBS-T 0,1 \% oder $5 \%$ BSA in TBS-T 0,1 \% an.

Die Färbung spezifischer Proteinbanden durch primäre Antikörper erfolgte, indem die Membran über Nacht (üN) bei $4^{\circ} \mathrm{C}$ in einer Antikörperlösung inkubiert wurde. 
Es folgten $3 \times 10$ minütiges Waschen in TBS-T $0,1 \%$ und $1 \mathrm{~h}$ Inkubation in sekundärem Antikörper anti-rabbit oder anti-mouse IgG-HRP. Danach wurde erneut $3 \times 10$ min in TBS-T 0,1\% gewaschen. An den sekundären Antikörper ist eine Meerrettichperoxidase gekoppelt (HRP, horseradish peroxidase), wodurch nach Aktivierung durch die Entwicklerlösung ein Chemilumineszenzsignal ausgestrahlt wird. Die Entwicklerlösung setzt sich aus einer luminolhaltigen Lösung und einer Peroxid-Lösung zusammen, die erst kurz vor Gebrauch in gleichen Teilen zusammen pipettiert und auf die Membran aufgetragen wurde. Nach einigen Minuten lichtgeschützter Inkubation wurde die ausgestrahlte Chemilumineszenz mit dem Luminescent Image Analyser detektiert.

Um eine Membran mehrfach zu färben, mussten die vorher verwendeten Antikörperkomponenten durch 15 minütiges Strippen in $1 \mathrm{x}$ reblot-mild-Lösung entfernt werden. Es folgte $3 \times 10$ min Waschen in TBS-T 0,1\% und $1 \mathrm{~h}$ Blocken in $5 \%$ Milch in TBS-T $0,1 \%$ oder $5 \%$ BSA in TBS-T 0,1\%. Hiernach wiederholten sich die Schritte wie im vorherigen Absatz.

\subsubsection{Zymographie}

Die Zymographie dient dem semiquantitativen Nachweis der enzymatischen Aktivität von Matrix-Metalloproteasen (MMPs). Die Probe wird auf speziellen Polyacrylamidgelen, die als Substrat der Proteasen Gelatine enthalten, elektrophoretisch aufgetrennt. Anschließend werden die Proteasen renaturiert und verstoffwechseln dann in einem Entwicklungspuffer das Substrat. Nach Färbung des Gels verbleiben die Bereiche mit aktiven Proteasen als helle Banden. Die hier verwendeten Gelatine-Gele weisen MMP2 und MMP9 nach.

Die Zellüberstände $(\mathrm{CM})$ wurden in gleichen Teilen mit $2 \times$ Probenpuffer gemischt. Das $10 \%$ Gelatine-Zymogramm-Gel wurde in Laufpuffer im BioRad Western Blot System eingespannt und je Tasche $24 \mu \mathrm{l}$ aufgetragen. Die Gelelektrophorese erfolgte bei $24 \mathrm{~mA}$ und $\mathrm{V}$ konstant, bis die Probe großzügig durchgelaufen war. Es schloss sich eine einstündige Renaturierung der Enzyme bei RT in der Renaturierungslösung an. Die Substratverdauung fand $48 \mathrm{~h}$ bei $37^{\circ} \mathrm{C}$ in Entwicklungspuffer statt. Die Gelatine im Gel wurde mindestens $1 \mathrm{~h}$ bei RT in Coomassie- 
Lösung gefärbt und die verdauten Bereiche danach 1-2 $\mathrm{h}$ in Entfärbungslösung wieder entfärbt, bis weiße Banden sichtbar wurden.

Die Gele konnten konserviert werden, indem sie 30 min bei RT in Fixierlösung geschwenkt und dann in ebenfalls darin getränkte Cellophan Folie eingespannt wurden. Die Konstruktion trocknete dann mindestens einen Tag.

\subsubsection{CAM-Assay}

Mithilfe des Chorion-Allantois-Membran(CAM)-Assays können Tumorgenese und Ausbreitungscharakteristika in vivo im befruchteten Hühnereimodell beobachtet werden. Dies umfasst die Freilegung der CAM, das Beimpfen mit kultivierten Burkitt-Lymphom-Zellen und schließlich das Ernten der sich durch die Blutgefäße der CAM versorgenden Tumoren. Die unterschiedliche Entwicklung der Tumoren wurde durch deren Ausmessung und Histologie verglichen.

\section{Freilegung der CAM}

Nach drei Tagen Bebrütung und regelmäßigem Wenden der Hühnereier bei $37,8^{\circ} \mathrm{C}$ und $80 \%$ Luftfeuchtigkeit, wurde mithilfe einer Säge in der Eischale ein kleines Fenster eröffnet. Damit sich der Embryo unter der Eihaut besser absenkt und er beim Entfernen dieser nicht verletzt wird, wurde zusätzlich seitlich in die Luftblase des Eis ein kleines Entlastungsloch gesägt und die Eihaut mit LockeLösung befeuchtet. Das Fenster wurde mit Leukosilk® verschlossen, die Hühnereier weiter im Brutschrank unter den genannten Bedingungen inkubiert.

\section{Beimpfen der CAM mit Burkitt-Lymphom-Zellen}

Die Beimpfung erfolgte sieben Tage nach der CAM-Freilegung, also am zehnten Tag der Embryonalentwicklung. Um gleiche Bedingungen zu schaffen, wurden alle Zellen zwei Tage vor Beimpfung zentrifugiert und im Medium I kultiviert. Das Matrigel wurde von $-20^{\circ} \mathrm{C}$ auf $-80^{\circ} \mathrm{C}$ gekühlt, um dann auf Eis bei $4{ }^{\circ} \mathrm{C}$ üN langsam aufzutauen. Pro Ei wurden je nach Versuch $1-3 \times 10^{6}$ Zellen in $20 \mu \mathrm{l}$ Matrigel aufgetragen. Die entsprechende Zellzahl wurde zentrifugiert $\left(120 \mathrm{~g}, 21^{\circ} \mathrm{C}, 7 \mathrm{~min}\right)$, der Überstand verworfen, das Zellpellet in dem verbliebenen Restmedium resuspendiert und in ein $1,5 \mathrm{ml}$ Reaktionsgefäß überführt. Nach erneuter 
Zentrifugation ( $400 \mathrm{~g}, 21 \mathrm{C}, 5 \mathrm{~min}$ ), wurde der Rest des Mediums abgenommen. Die Zellen wurden nun im Matrigel gelöst und sofort auf Eis gelagert. Pro Ei wurden $20 \mu \mathrm{l}$ dicht an der CAM aufgetragen.

\section{Extraktion der Tumoren}

Vier Tage nach der Beimpfung, also am 14. Tag der Embryonalentwicklung, wurden die Tumoren mit einer Pinzette aus der CAM geschnitten, in PBS gewaschen und zwischengelagert. Die Tumoren wurden am selben Tag nativ lichtmikroskopisch fotografiert. Mit den entstandenen Fotos wurde später die Tumorfläche mit dem Programm Image $\mathrm{J}$ ermittelt. Die den GFP-Vektor enthaltenden Lymphome konnten zudem fluoreszenzmikroskopisch analysiert werden.

\subsubsection{Histologische Methoden}

\subsubsection{Fixierung und Einbettung der Tumoren in Paraffin}

Die Tumoren wurden mindestens drei Tage in wässriger Bouin-Lösung bei $4{ }^{\circ} \mathrm{C}$ fixiert, danach über mehrere Tage in $70 \%$ Ethanol gewaschen. Die fixierten Tumoren wurden maschinell im Shandon Citadel 2000 Tissue Processor für die Einbettung in Paraffin vorbereitet. Zum Entwässern durchliefen sie dabei eine aufsteigende Ethanolreihe (70 \% für 3 h, $80 \%$ für 1 h, $90 \%$ für 1 h, $96 \%$ für 1 h, $99 \%$ für $2 \mathrm{~h}$ ) und verblieben danach für $1,5 \mathrm{~h}$ in Isopropanol. Nach dreimaliger Inkubation in Xylol (30 min, $45 \mathrm{~min}, 45 \mathrm{~min}$ ) wurden sie zunächst für $30 \mathrm{~min}$, danach für $7 \mathrm{~h}$ bei $60^{\circ} \mathrm{C}$ durch Paraplast Plus ${ }^{\circledR}$ infiltriert. Hiernach erfolgte die Einbettung der Präparate senkrecht ausgerichtet in Paraplast Plus ${ }^{\circledR}$ in kleine Einbettkassetten. Die ausgehärteten Paraffinblöcke wurden mit dem Microtom 3 - $4 \mu \mathrm{m}$ dick geschnitten, üN getrocknet und anschließend gefärbt.

\subsubsection{Hämatoxylin-Eosin-Färbung}

Die Tumorschnitte wurden maschinell mit dem Varistain ${ }^{\mathrm{TM}}$ 24-4 Automatic Slide Stainer durch Hämatoxylin/Eosin (HE) gefärbt. Hierbei wurden sie zunächst $2 \times 5 \mathrm{~min}$ in Xylol entparaffiniert, durchliefen dann eine absteigende Ethanolreihe (je 2 min $99 \%, 96 \%, 80 \%$ und $60 \%$ ), wurden 2 min in destilliertem Wasser getränkt und anschließend 4 min in Mayers Hämalaun-Lösung inkubiert. Es schloss sich ein einminütiges Waschen in destilliertem Wasser, gefolgt von einem 
15minütigen Waschen unter fließendem Leitungswasser an. 7 min Färbung in Eosin, 1 min Waschen in destilliertem Wasser, je 1 min in $60 \%, 80 \%, 96 \%$ Ethanol und $2 \times 2$ min in $99 \%$ Ethanol und abschließende Überführung in Xylol vollendente die HE-Färbung. Im feuchten Zustand wurden sie schließlich mit DPX Eindeckmedium und Deckgläsern eingedeckt. Nach dem Trocknen üN konnten die Schnitte lichtmikroskopisch analysiert und fotografiert werden.

\subsubsection{Statistik}

Die Ergebnisse der Experimente wurden als Mittelwert \pm Standardabweichung des Mittelwerts (Mittelwert \pm SD) angegeben. Gruppenergebnisse wurden statistisch mittels ANOVA-Verfahren (one-way analysis of variance) bzw. Kruskal-Wallis-Test und anschließendem Dunnett-post-Test oder Dunn's multiple comparison-Test verglichen. Zum Vergleich zweier parametrischer Gruppen wurde der T-Test angewendet. Die erforderlichen Testbedingungen, Normalverteilung und Varianzgleichheit, wurden mithilfe des Kolmogorov-Smirnov-Tests bzw. des F-Tests ermittelt. Kreuztabellen wurden mithilfe des exakten Tests nach Fisher ausgewertet. Das Signifikanzniveau lag bei ${ }^{*}, p<0,05 ;{ }^{* *}, p<0.01 ;{ }^{* *}, p<0,001$. Die Analysen wurden mit GraphPad Prism 5.04 und IBM SPSS Statistics 24 durchgeführt. 


\section{Ergebnisse}

\subsection{Der Einfluss von LEF1 auf die Tumormorphologie im CAM- Xenograft-Modell verschiedener Burkitt-Lymphom-Zelllinien}

Zur Charakterisierung des Einflusses von LEF1 im In-vivo-Xenograft-Modell der humanen Burkitt-Lymphom-Zelllinien BL-30 und BL-41 wurde der in Vorarbeiten der Arbeitsgruppe für das Burkitt-Lymphom etablierte Chorion-Allantois-MembranAssay verwendet (Becker et al. 2012; Klingenberg et al. 2014).

\subsubsection{LEF1-knockdown in CAM-Tumoren der Zelllinie BL-30}

\subsubsection{Analysen von BL-30-CAM-Tumoren mit einer applizierten Zahl von $2 \times 10^{6}$} Zellen

Verwendet wurden zu Beginn zwei BL-30-Subklone mit LEF1-KD (BL-30 LEF1 sh1, BL-30 LEF1 sh2), in späteren Versuchen konnte eine dritte KD-Zelllinie hinzugezogen werden (BL-30 LEF1 sh3). Als Vergleich dienten zwei Kontrollen, die eine scrambled-shRNA exprimieren (BL-30 ctrl 1, BL-30 ctrl 2) und die WildtypZellinie BL-30. Parallel zu jedem CAM-Assay wurde der LEF1-KD mittels Westernblot überprüft. In Abbildung 3-1 lässt sich ein LEF1-KD in den genetisch veränderten Zellklonen BL-30 LEF1 sh1, sh2 und sh3 erkennen, wohingegen der Wildtyp und die beiden Kontrollen (BL-30 ctrl 1, BL-30 ctrl 2) wie erwartet LEF1 synthetisieren. Außerdem wurde vor dem CAM-Versuch der stabile Einbau des pGIPZ-Konstrukts in die transduzierten Zellklone durch Messung des GFPGehaltes mittels FACS-Analyse überprüft sowie am Ende des CAM-Assays die GFP-Expression mittels Fluoreszenzmikroskopie dargestellt (Abbildung 3-2). Aufgrund der Expressionskassette im pGIPZ-Konstrukt kann der GFP-Gehalt als Indikator für das Maß gesehen werden, in dem die transduzierte shRNA im Genom der Zellen abgelesen wird. 


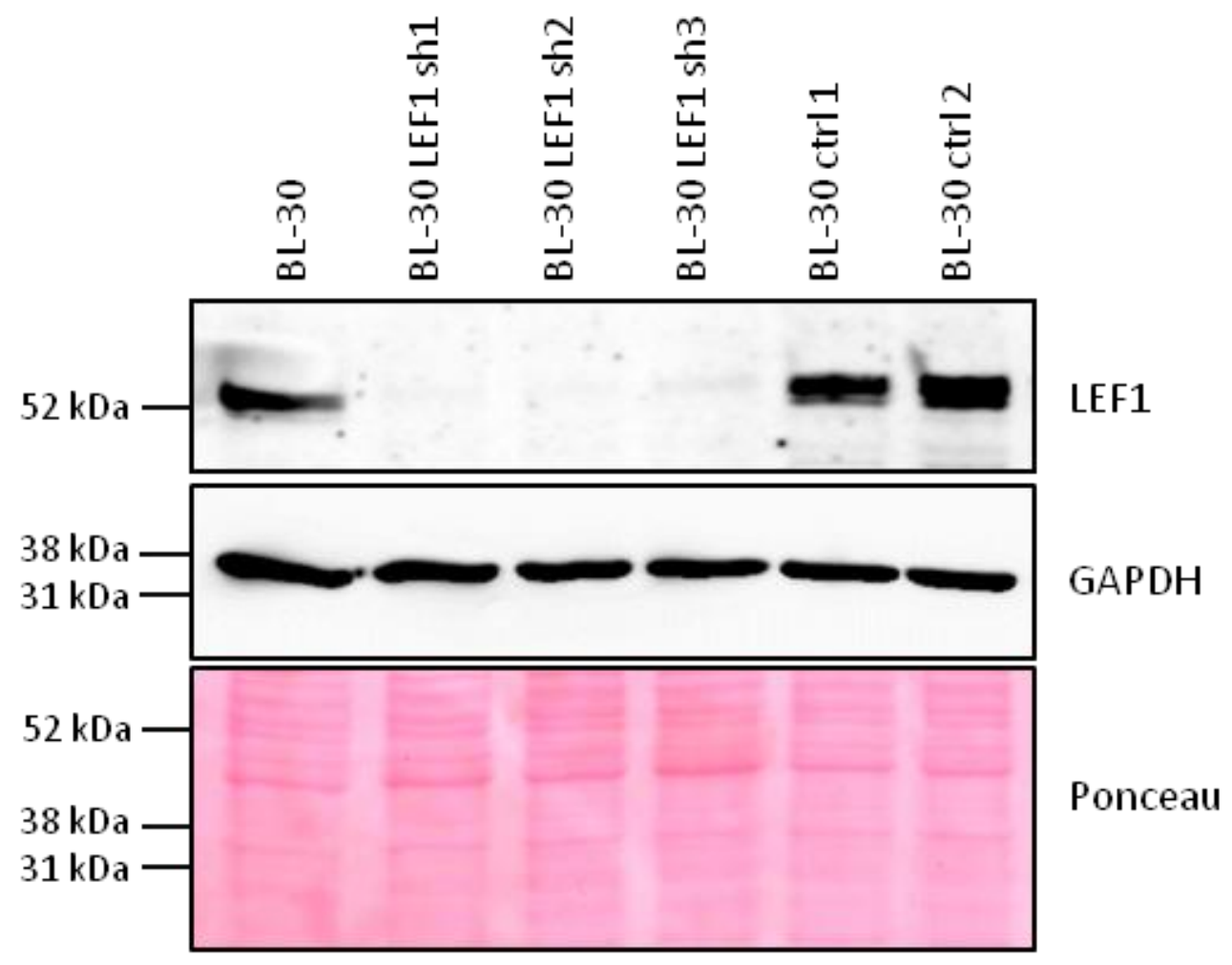

Abbildung 3-1: Repräsentativer Nachweis der LEF1-Expression in BL-30-Zellen. Die Abbildung zeigt vergleichende Immunoblotanalysen von BL-30-Zellen, in denen die LEF1-Proteinmenge nach LEF1-RNA-Interferenz-vermitteltem KD reduziert wurde. Dargestellt sind die parentale BL-30Zelllinie sowie die LEF1-shRNA-exprimierenden Subzellinien BL-30 LEF1 sh1, BL-30 LEF1 sh2 und BL-30 LEF1 sh3. Zum Vergleich dienen die scrambled-shRNA-exprimierenden Kontrollzelllinien BL-30 ctrl 1 und BL-30 ctrl 2, die nicht an Sequenzen im humanen Genom binden können und somit auch keinen LEF1-KD verursachen. GAPDH und Ponceau-Färbung dienen als Beladungskontrollen. Auf der linken Seite der Abbildung sind die Proteinmassen entsprechend den genutzten Größenmarkern angegeben. 

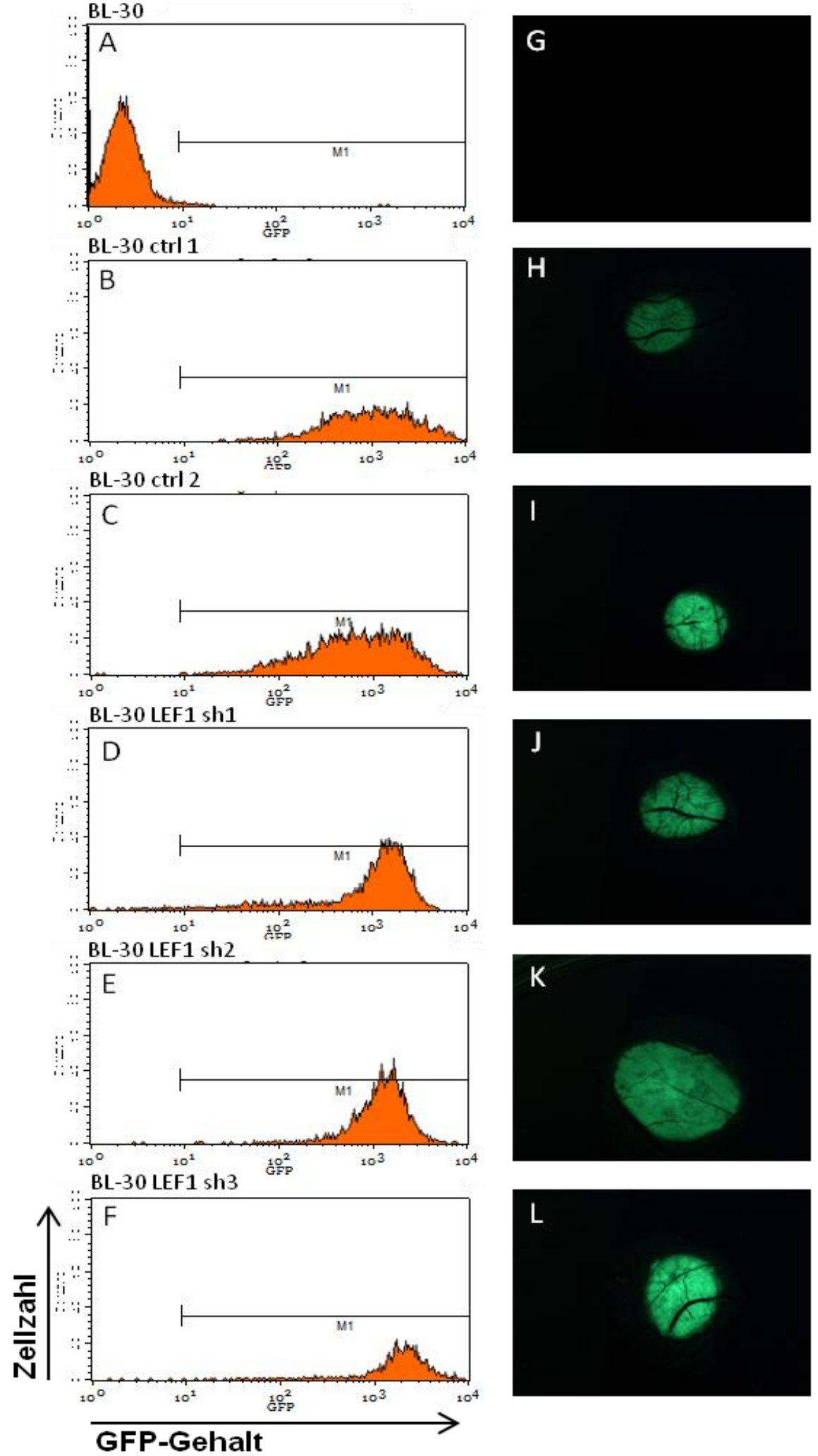

Abbildung 3-2: Detektion der GFP-Expression in den BL-30-Zellen mittels Durchflusszytometrie und in CAM-Tumoren durch Fluoreszenzmikroskopie. Die repräsentativen FACSAnalysen stellen die GFP-Fluoreszenz der viral transduzierten Zellen aufgetragen gegen die Zellzahl dar (A-F). Der Wildtyp BL-30 (A, G) ist genetisch unverändert und weist somit auch keine 
GFP-Fluoreszenz auf. Jeweils rechts der FACS-Analyse ist die Fluoreszenzaufnahme eines entsprechenden CAM-Tumors dargestellt (G-L).

Um die In-ovo-Auswirkungen des LEF1-KD in der Zelllinie BL-30 zu charakterisieren wurden die zuvor beschriebenen in vitro kultivierten Zelllinien auf die CAM von Hühnerembryonen aufgetragen (siehe Kapitel 2.2.5). Zunächst standen nur zwei Zelllinien mit reduzierter LEF1-Expression zur Verfügung (BL-30 LEF1 sh1 und sh2). Die Beimpfung der CAM wurde in den im Folgenden beschriebenen Versuchen mit $2 \times 10^{6}$ Zellen pro Ei durchgeführt. Die entstandenen soliden und scharf begrenzten Tumoren wurden nach vier Tagen Bebrütung geerntet, nativ licht- und fluoreszenzmikroskopisch fotografiert und anschließend histologisch aufgearbeitet. Die histologischen Präparate wurden dann auf morphologische Besonderheiten hin untersucht. Tabelle 3-1 zeigt eine Übersicht der geernteten Neoplasien und deren durchschnittliche Größe. Differenzen zwischen der Anzahl der geernteten Tumoren und der Zahl initial beimpfter Eier gehen auf Verluste durch Tod der Hühnerembryonen, Kontaminationen und unzureichendes Anwachsen der Tumoren zurück. Insgesamt konnten 67 von 80 Tumoren ausgewertet werden.

Tabelle 3-1: Übersicht über die BL-30-CAM-Tumoren ( $2 \times 10^{6}$ applizierte Zellen). Die Tabelle stellt die in zwei biologischen Replikaten geernteten CAM-Tumoren der verschiedenen BL-30Subklone und die durchschnittliche Größe dar. Angegeben ist die Anzahl der geernteten Tumoren, in Klammern die Zahl der initial beimpften Eier. $2 \times 10^{6}$ Zellen in $20 \mu$ l Matrigel, 4 d Inkubation.

\begin{tabular}{|c|c|c|c|}
\hline \multirow[t]{2}{*}{ Zelllinie } & \multicolumn{2}{|c|}{$\begin{array}{c}\text { Zahl der geernteten Tumoren an den } \\
\text { initial beimpften Eiern }\end{array}$} & \multirow[t]{2}{*}{$\begin{array}{l}\text { Mittelwert der Tumor- } \\
\text { flächen }\left[\mathrm{cm}^{2}\right]\end{array}$} \\
\hline & 1. CAM-Assay & 2. CAM-Assay & \\
\hline BL-30 & $5(8)$ & $5(7)$ & 0,300 \\
\hline BL-30 ctrl 1 & $9(10)$ & $5(6)$ & 0,214 \\
\hline $\mathrm{BL}-30 \mathrm{ctrl} 2$ & $9(10)$ & $6(6)$ & 0,221 \\
\hline BL-30 LEF1 sh1 & $8(9)$ & $6(7)$ & 0,316 \\
\hline BL-30 LEF1 sh2 & $9(10)$ & $5(7)$ & 0,334 \\
\hline
\end{tabular}

In Abbildung 3-3 A sind die Größen der einzelnen Subzelllinien zusammenfassend graphisch dargestellt. In der Größenanalyse konnte festgestellt werden, dass die Kontrollzelllinien durchschnittlich kleiner sind als die Wildtyp-Zelllinie. Außerdem zeigen sich beide Kontrollen signifikant kleiner als die Zelllinie BL-30 LEF1 
sh2. Die KD-Zelllinien und die BL-30 sind dagegen in ihrer Durchschnittsgröße vergleichbar. Werden die aberrant LEF1-exprimierenden Tumoren und die LEF1KD-Neoplasien zu jeweils einer Gruppe zusammengefasst, sind die KD-Tumoren immer noch signifikant größer (Abbildung 3-3 B).
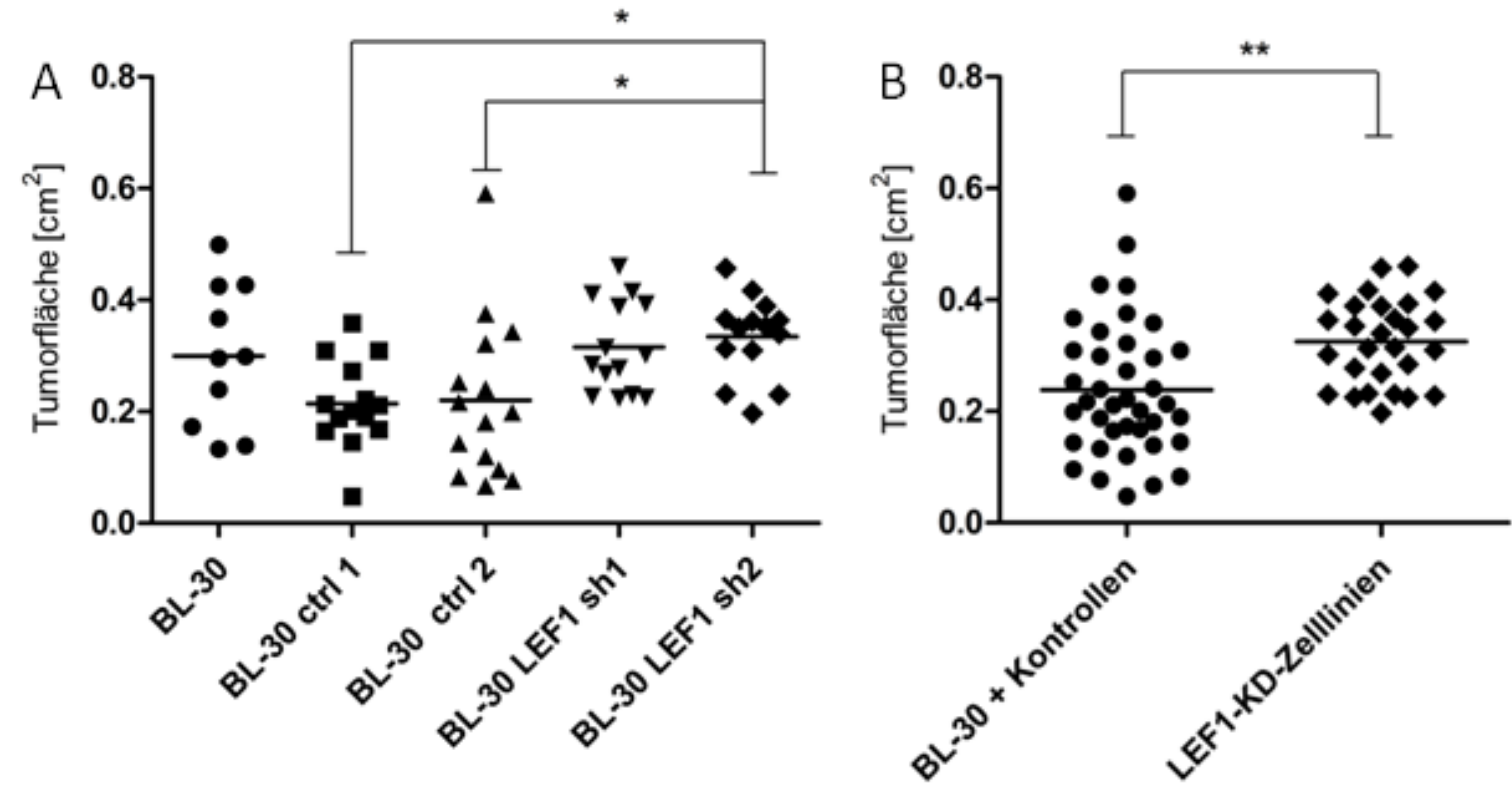

Abbildung 3-3: Größenvergleich der BL-30-CAM-Tumoren (2 x $10^{6}$ applizierte Zellen). In der Grafik A sind die Größen der Tumoren in Form ihrer Fläche der einzelnen Zelllinien mit Mittelwert dargestellt. Die Zelllinie BL-30 LEF1 sh2 bildet signifikant größere Tumoren als die beiden Kontrollen BL-30 ctrl 1 und 2. Auffällig ist, dass die beiden Kontrollen sichtbar kleiner sind, als die parenterale BL-30 und diese auch keinen Größenunterschied zu den KD-Zelllinien zeigt. In Grafik B sind die aberrant LEF1-exprimierenden Zellen und die KD-Zelllinien zu jeweils einer Gruppe zusammengefasst. Auch hier ist der Unterschied signifikant. A: Kruskal-Wallis-Test mit anschließendem Dunn's multiple comparison-Test; ${ }^{*} p<0,05$; B: T-Test; ${ }^{* *} p<0,01.2 \times 10^{6}$ Zellen in $20 \mu$ l Matrigel, $4 \mathrm{~d}$ Inkubation.

Insgesamt findet sich demnach ein Größenunterschied in Form der Fläche zwischen den LEF1-exprimierenden und LEF1-defizienten Tumoren. Die Kontrollzelllinien bilden dabei aber kleinere Tumoren als die parenterale BL-30.

Die Analyse der geernteten CAM-Tumoren zeigte, dass diese unabhängig vom LEF1-Status in 83,6 \% der Fälle (56 von 67 geernteten Tumoren) am nativen Präparat sichtbare hämorrhagische Nekrosen aufwiesen. Der Anteil der hämorrhagischen Tumoren an der Tumorgesamtzahl der einzelnen Subzellinien ist in Abbil- 
dung 3-4 dargestellt. In der statistischen Analyse findet sich keine signifikante Abhängigkeit zwischen der Anzahl der eingebluteten Tumoren und der Subzelllinie.

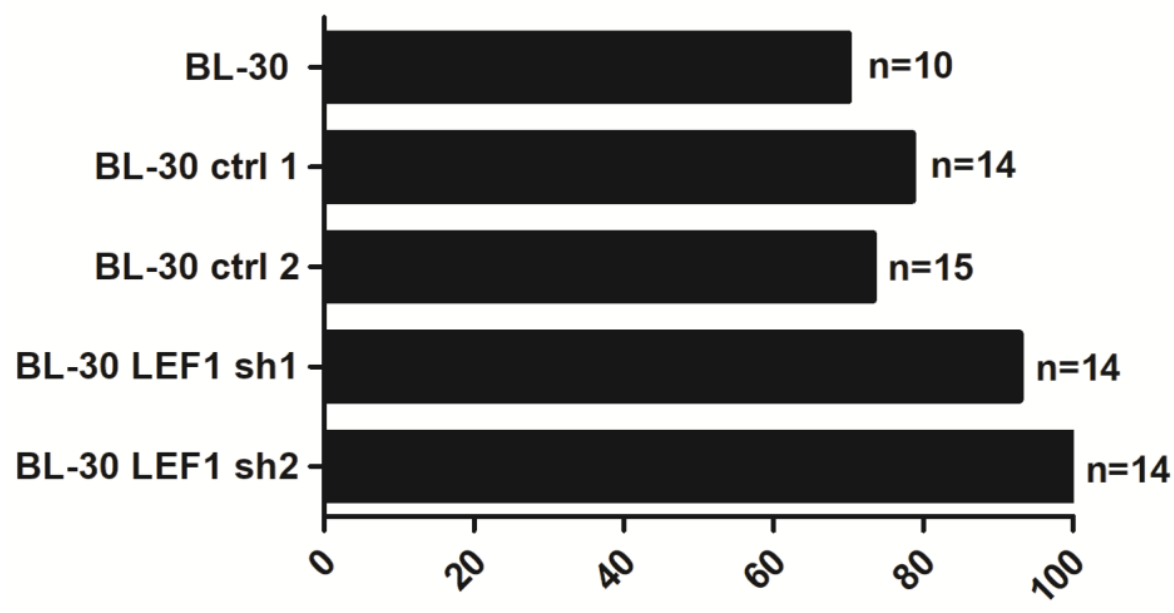

Anteil der hämorrhagischen Tumoren [\%]

Abbildung 3-4: Anteil der hämorrhagischen Tumoren an der Tumorgesamtzahl $\left(2 \times 10^{6}\right.$ applizierte Zellen). Die Grafik zeigt den prozentualen Anteil der hämorrhagischen Tumoren an der Gesamtzahl (n) der geernteten Präparate. Der Transkriptionsfaktor LEF1 begünstigt keine Einblutungen im BL-30-CAM-Modell. Die LEF1-KD-Zelllinien BL-30 LEF1 sh1 und sh2 zeigen tendenziell sogar häufiger Einblutungen als die Kontrollen und die Wildtyp-Zelllinie im nativen Präparat. Die Zahl der Einblutungen ist allerdings nicht signifikant abhängig von der Subzellinie. Exakter Test nach Fisher bei $p<0,05.2 \times 10^{6}$ Zellen in $20 \mu$ l Matrigel, 4 d Inkubation.

Hier wird deutlich, dass bei LEF1-Expression keine hämorrhagischen Nekrosen in BL-30-Zellen begünstigt werden.

Nach der histologischen Aufarbeitung zeigen sich die Tumorzellen im HE-Schnitt dicht an dicht und füllen den Tumor gänzlich aus (Abbildung 3-5 F-J). Es finden sich im Zentrum kaum Überreste des Matrigels, in dem die Zellen appliziert wurden. Im Lymphomgewebe finden sich analog zu den nativ sichtbaren Einblutungen (Abbildung 3-5 A-E) reichlich freie Erythrozyten, die im Gegensatz zum Menschen beim Huhn kernhaltig sind (Abbildung 3-5 K-O). Im Randbereich sind die dort verstärkt auftretenden Gefäße eng im Lymphom-Zellverband eingeschlossen (Abbildung 3-5 K-M und O). In diesem dichten Erscheinungsbild war es nicht möglich, eine vessel co-option zu beobachten (Abbildung 3-5 K-O). 

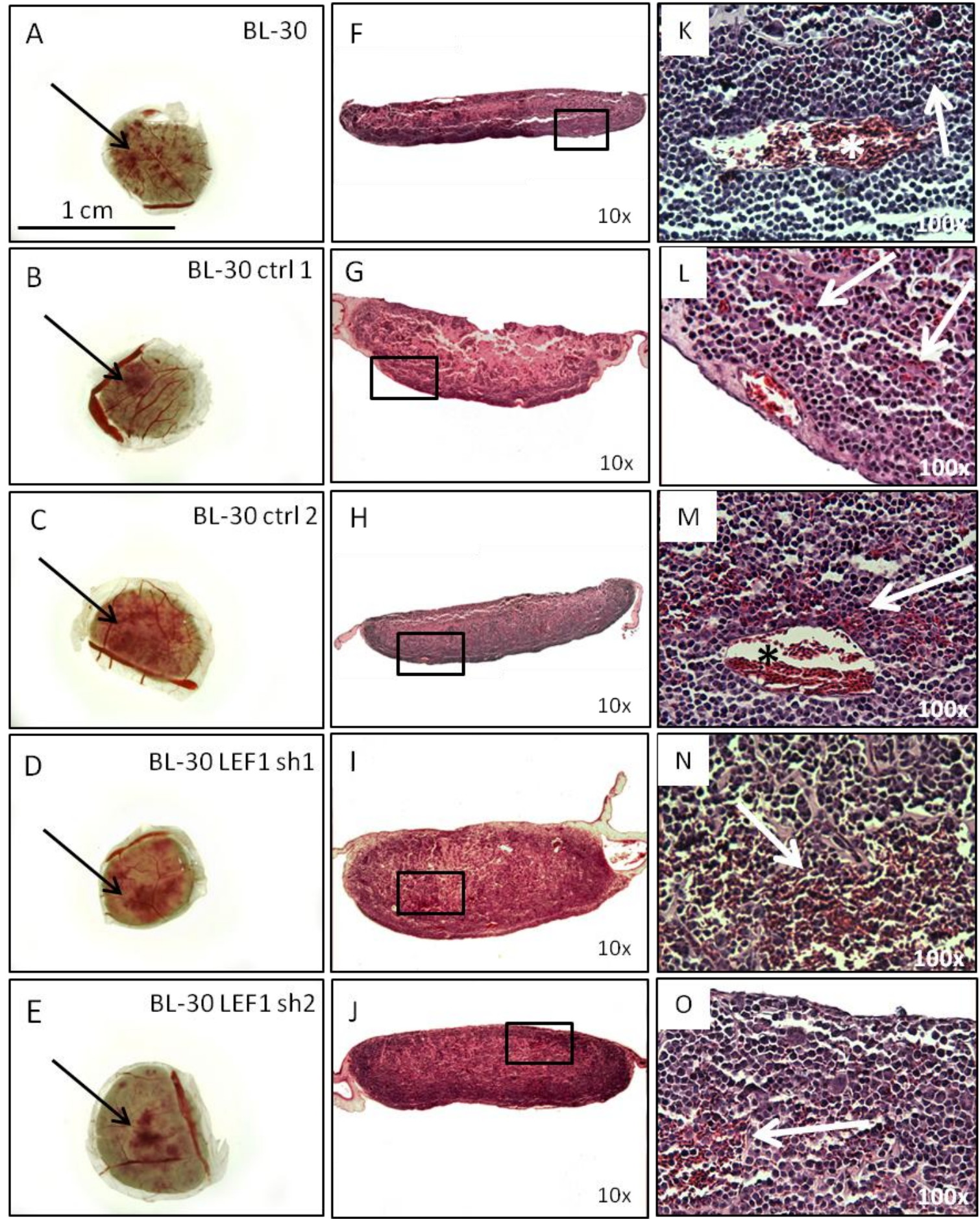

Abbildung 3-5: Übersicht über repräsentative mikroskopische Aufnahmen ausgewählter CAM-Tumoren. Alle Subzellinien verfügen sehr häufig über sichtbare Einblutungen, die in A-E genauer dargestellt sind und eine hohe Zelldichte (F-J). Rechts der Hellfeldaufnahme eines repräsentativen Tumors sind die jeweils daraus gefertigten Schnitte abgebildet. Sowohl die parenterale BL-30 (A, F, K) und die Kontrollen (B, G, L: BL-30 ctrl 1 und C, H, M: BL-30 ctrl 2) als auch die LEF1-KD-Zelllinien BL-30 LEF1 sh1 (D, I, N) und sh2 (E, J, O) zeigen regelhaft makroskopisch (AE) und mikroskopisch Hämorrhagien (K-O) im Tumorgewebe. Schwarzer Pfeil: Einblutungen. Wei- 
Ber Pfeil: eosinophile kernhaltige Erythrozyten zwischen den Tumorzellen. Stern: Blutgefäß. $2 \times 10^{6}$ Zellen in $20 \mu \mathrm{l}$ Matrigel, $4 \mathrm{~d}$ Inkubation, Bouin-fixiert, HE-gefärbt, Schnittdicke 3-4 $\mu \mathrm{m}$.

Um festzustellen, ob mögliche Effekte des LEF1-KD durch die große Anzahl der BL-30-Zellen im geernteten Präparat maskiert werden, wurde eine Versuchsreihe angeschlossen, in der die auf die CAM aufgetragene Zellzahl um $50 \%$ auf $1 \times 10^{6}$ reduziert wurde.

\subsubsection{Analysen von BL-30-CAM-Tumoren mit einer applizierten Zahl von $1 \times 10^{6}$ Zellen}

In den folgenden Untersuchungen wurde getestet, ob sich morphologische Unterschiede zwischen LEF1-aberranten und LEF1-reduzierten BL-30-CAM-Tumoren bei einer geringeren Anzahl der auf die CAM gegebenen Lymphomzellen erkennen lassen. In dem anschließend beschriebenen CAM-Assay konnten die KDZelllinien um eine weitere ergänzt werden (BL-30 LEF1 sh3).

Tabelle 3-2 gibt eine Übersicht über die Anzahl der pro Zelllinie geernteten CAMNeoplasien und deren durchschnittliche Größe.

Tabelle 3-2: Übersicht über die BL-30-CAM-Tumoren ( $1 \times 10^{6}$ applizierte Zellen). Die Tabelle stellt die geernteten CAM-Tumoren der verschiedenen BL-30-Subklone und deren durchschnittliche Größe dar. Angegeben ist die Anzahl der geernteten Tumoren, in Klammern die Zahl der initial beimpften Eier. $1 \times 10^{6}$ Zellen in $20 \mu$ l Matrigel, $4 \mathrm{~d}$ Inkubation.

\begin{tabular}{|l|c|c|}
\hline \multicolumn{1}{|c|}{ Zelllinie } & $\begin{array}{c}\text { Zahl der geernteten Tumoren an den } \\
\text { initial beimpften Eiern in einem CAM- } \\
\text { Assay }\end{array}$ & $\begin{array}{c}\text { Mittelwert der Tumor- } \\
\text { flächen [cm }{ }^{2} \text { ] }\end{array}$ \\
\hline BL-30 & $5(6)$ & 0,210 \\
\hline BL-30 ctrl 1 & $2(5)$ & 0,235 \\
\hline BL-30 ctrl 2 & $4(5)$ & 0,118 \\
\hline BL-30 LEF1 sh1 & $4(5)$ & 0,231 \\
\hline BL-30 LEF1 sh2 & $3(5)$ & 0,386 \\
\hline BL-30 LEF1 sh3 & $5(6)$ & 0,233 \\
\hline
\end{tabular}

In Abbildung 3-6 A sind die einzelnen Tumorgrößen graphisch aufgetragen. Die BL-30 ctrl 2 ist unterdurchschnittlich klein und die BL-30 LEF1 sh2 erneut überdurchschnittlich groß. Die weiteren Zelllinien unterscheiden sich kaum in ihrer Tu- 
morgröße. Werden die parenterale BL-30 mit den beiden Kontrollen bzw. die KDZellinien zusammengefasst, zeigt sich insgesamt ein signifikanter Größenunterschied zugunsten der KD-Tumoren (Abbildung 3-6 B).
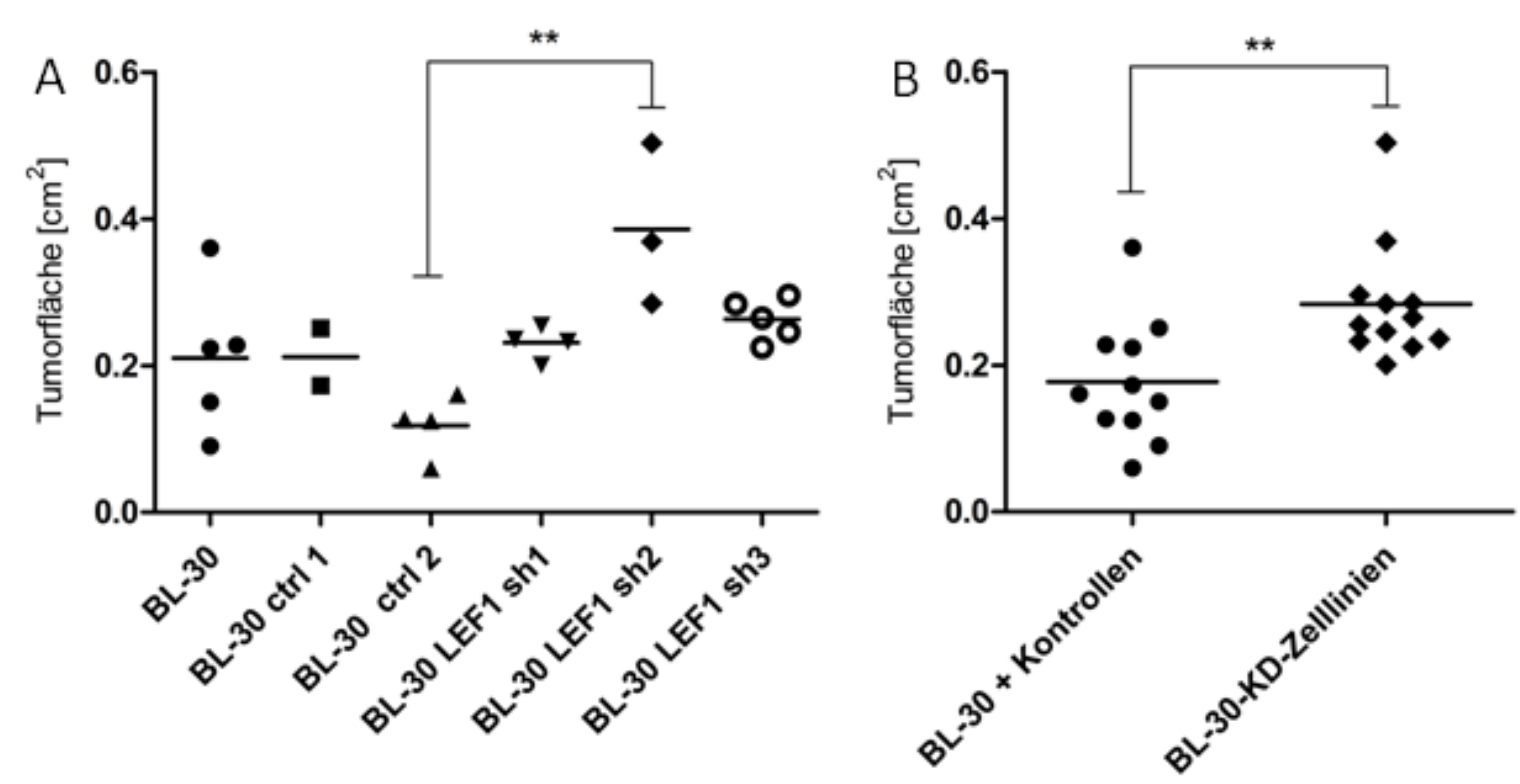

Abbildung 3-6: Größenvergleich der BL-30-CAM-Tumoren (1 $\times 10^{6}$ applizierte Zellen). In der Grafik A sind die Größen der Tumoren in Form ihrer Fläche der einzelnen Zelllinien mit Mittelwert dargestellt. Die Zelllinie BL-30 LEF1 sh2 bildet signifikant größere Tumoren als die Kontrolle BL-30 ctrl 2. Die restlichen Zelllinien zeigen eine vergleichbare Größe. In Grafik B sind die aberrant LEF1exprimierenden Zellen und die KD-Zelllinien zu jeweils einer Gruppe zusammengefasst. Hier zeigt sich insgesamt ein signifikanter Unterschied. A: Kruskal-Wallis-Test mit anschließendem Dunn's multiple comparison-Test; ${ }^{*} \mathrm{p}<0,05$; B: T-Test; ${ }^{* *} \mathrm{p}<0,01.2 \times 10^{6}$ Zellen in $20 \mu \mathrm{l}$ Matrigel, $4 \mathrm{~d}$ Inkubation.

Es findet sich demnach auch bei einer geringeren applizierten Zellzahl ein GröBenunterschied in Form der Fläche zwischen den LEF1-exprimierenden und LEF1-defizienten Tumoren, wobei dieser in besonderem Maße durch zwei der sechs Zelllinien bedingt ist. Insgesamt sind die Ergebnisse konsistent mit Abbildung 3-3.

In den Hellfeldaufnahmen der Abbildung 3-7 werden beispielhafte Tumoren der sechs Zelllinien gezeigt. Hämorrhagische Nekrosen am frisch geenteten Präparat waren trotz der Reduktion der Zellzahl bei 60,9\% aller geernteten Tumoren sichtbar (14 von 23 Tumoren), auch wenn die Blutungen insgesamt schwächer als bei 
$2 \times 10^{6}$ applizierten Zellen ausfielen (Abbildung 3-7 C-E). Die LEF1-KD-Zelllinie BL-30 LEF1 sh2 zeigt sogar häufiger Einblutungen als Kontrollen und Wildtyp, wobei sich insgesamt keine Abhängigkeit zwischen Zelllinie und Anzahl der hämorrhagischen Tumoren nachweisen lässt (Abbildung 3-8).
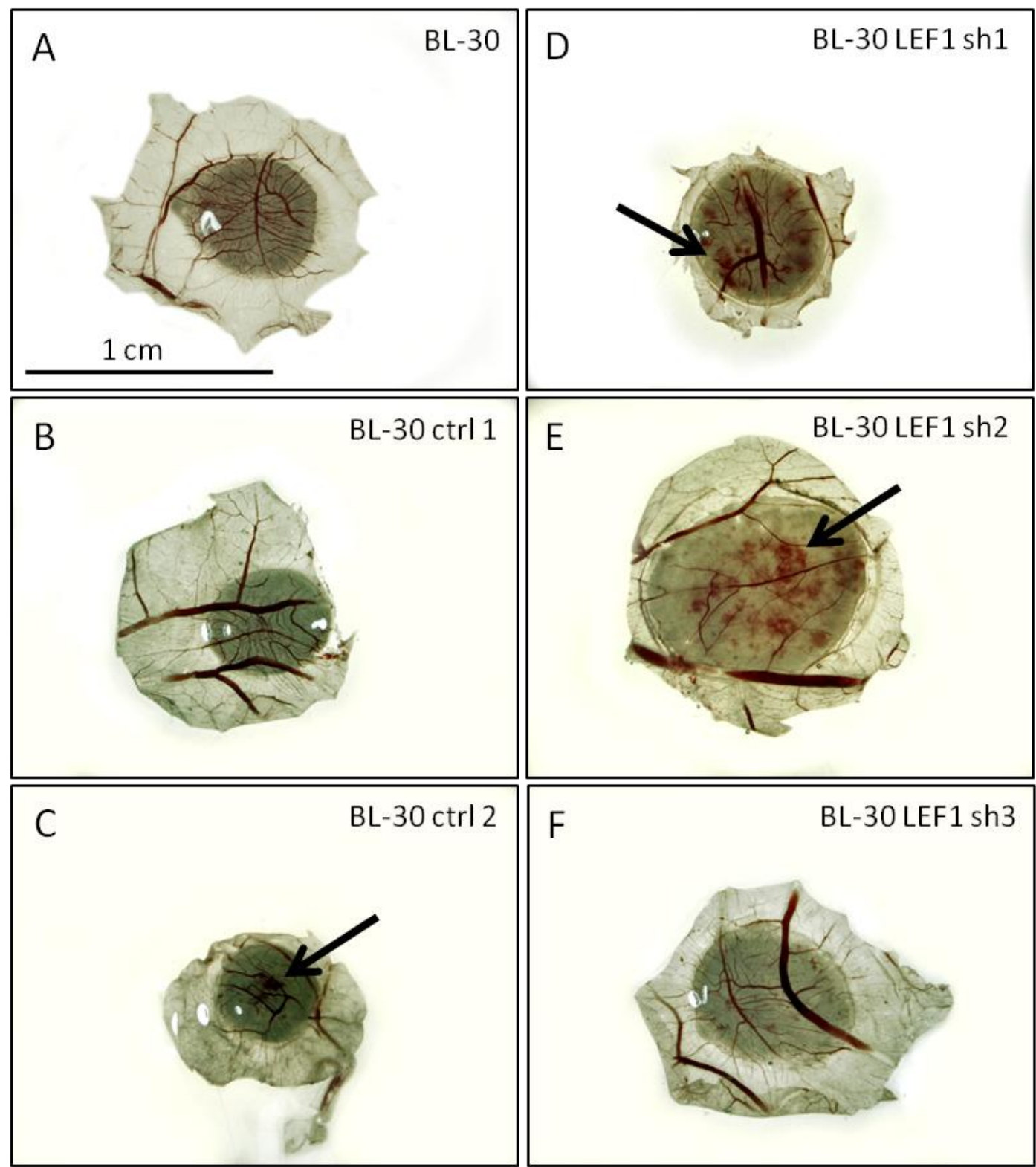

Abbildung 3-7: Lichtmikroskopische Aufnahmen der BL-30-Tumoren (1 x $10^{6}$ applizierte Zellen). Die Fotos zeigen repräsentative Aufnahmen der sechs verschiedenen BL-30-Zelllinien. Sowohl aberrant LEF1-exprimierende (A-C) als auch LEF1-defiziente BL-30-Tumoren (D-F) zeigen regelmäßig Hämorrhagien. Pfeil: hämorrhagischer Bereich. 1 x $10^{6}$ Zellen in $20 \mu \mathrm{l}$ Matrigel, $4 \mathrm{~d}$ Inkubation. 


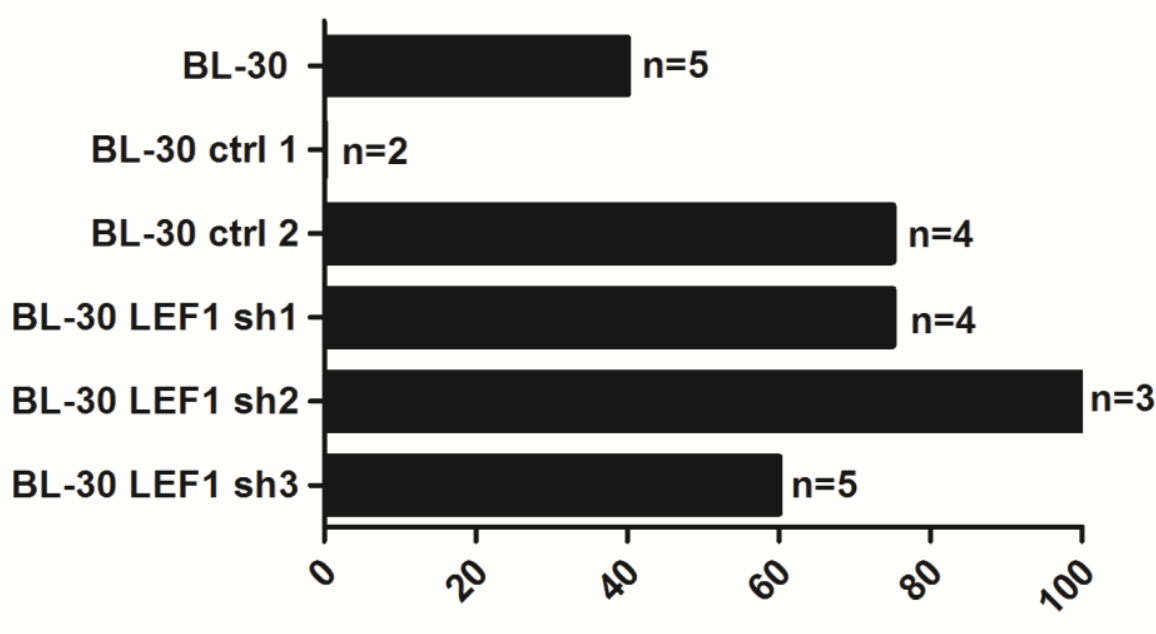

Anteil der hämorrhagischen Tumoren [\%]

Abbildung 3-8: Anteil der hämorrhagischen Tumoren an der Tumorgesamtzahl ( $1 \times 10^{6}$ applizierte Zellen). Die Grafik zeigt den prozentualen Anteil der hämorrhagischen Tumoren an der Gesamtzahl (n) der geernteten Präparate. Der Transkriptionsfaktor LEF1 begünstigt keine Einblutungen im BL-30-CAM-Modell. Die LEF1-KD-Zellinie BL-30 LEF1 sh2 zeigt sogar häufiger Einblutungen als Kontrollen und Wildtyp-Zellinie im nativen Präparat. Die Zahl der Einblutungen ist nicht signifikant abhängig von der Subzelllinie. Exakter Test nach Fisher bei $p<0,05.1 \times 10^{6}$ Zellen in $20 \mu$ l Matrigel, 4 d Inkubation.

Auf histologischer Ebene fanden sich ebenfalls keine signifikanten morphologischen Abweichungen zwischen LEF1-exprimierenden Tumoren und Neoplasien mit reduzierter LEF1-Menge. Die Zelldichte der entstandenen Tumoren ist insgesamt sichtbar geringer als bei der doppelten aufgetragenen Zellzahl, welches durch das teilweise zwischen den Lymphomzellen noch sichtbare gleichmäßig eosinophil gefärbte Matrigel deutlich wird (Abbildung 3-9 Vergrößerungen rechts). Auch freie Erythrozyten finden sich seltener, was sich mit den zwar in 60,9\% der Fälle vorhandenen, aber sich nicht immer über den gesamten Tumor ausbreitenden Blutungen deckt (vergl. Abbildung 3-7 und Abbildung 3-9). Alle Zelllinien verfügen nach wie vor über keine herausragende Neigung, sich in ihrer Ausbreitung nach Blutgefäßen zu richten und zeigen ein ähnliches Maß an unverdautem Matrigel (Abbildung 3-9). Im Tumorrandbereich ist regelmäßig eine bindegewebige "Abkapselung" der Lymphomzellen zum CAM-Gewebe zu erkennen (Abbildung 3-9 B, D, F, H, L). 

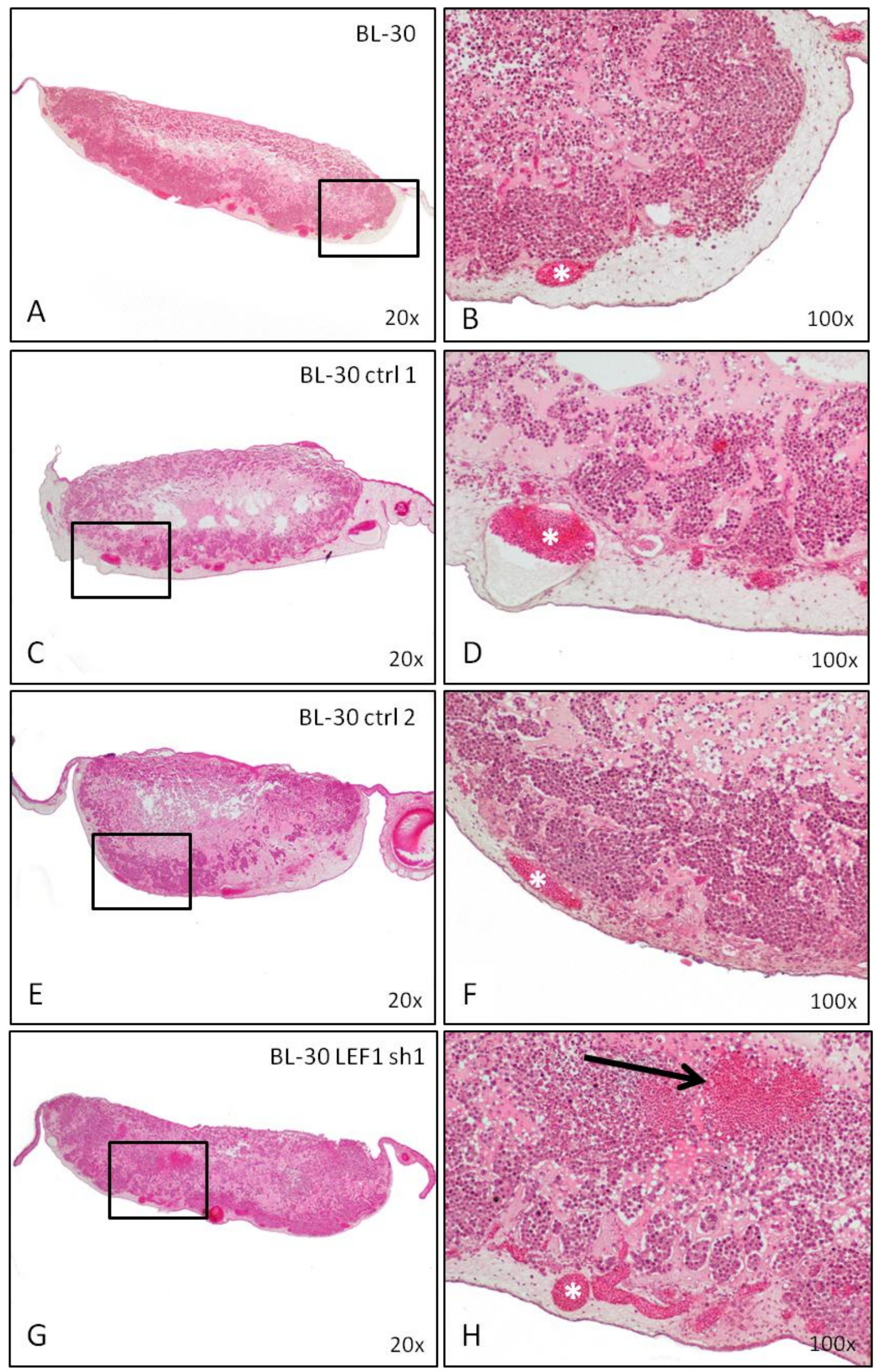

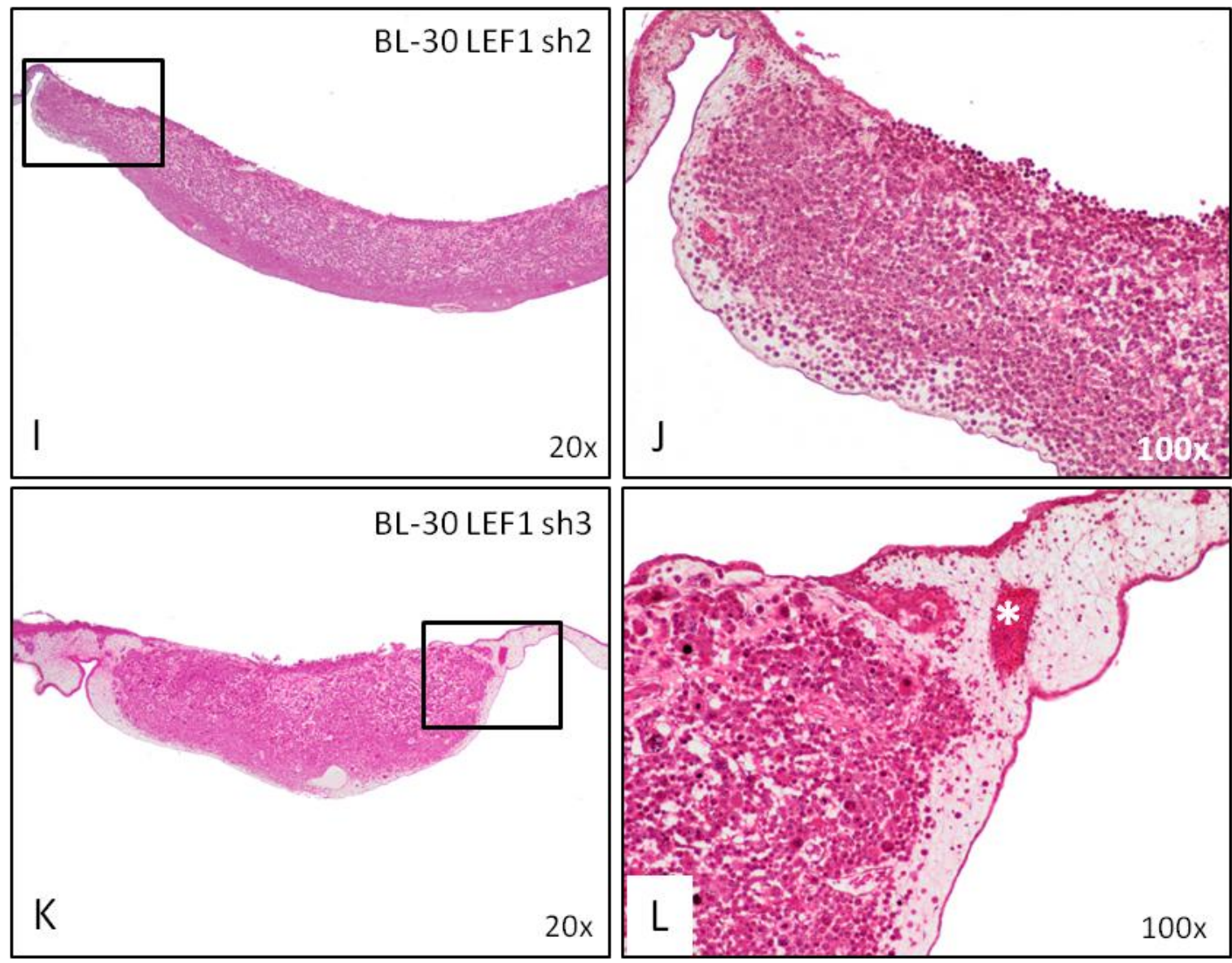

Abbildung 3-9: Übersicht über BL-30-CAM-Tumoren (1 x 106 applizierte Zellen). Die Abbildung zeigt in A-F repräsentative Tumoren der Subzelllinien mit aberranter LEF1-Expression und in G-L Tumoren der Zelllinien mit reduzierter LEF1-Menge. Rechts ist jeweils ein vergrößerter Ausschnitt aus der linken Übersichtsaufnahme abgebildet. Auch bei $1 \times 10^{6}$ beimpften Zellen führt ein LEF1$\mathrm{KD}$ zu keinen morphologischen Besonderheiten wie vessel co-option: Die Blutgefäße (Stern) im Randbereich sind nicht in besonderer Form von Lymphomzellen umringt $(\mathrm{H}, \mathrm{J}, \mathrm{L})$. $\mathrm{G}$ und $\mathrm{H}$ zeigen einen repräsentativen Tumor der KD-Zelllinie BL-30 LEF1 sh1, bei dem ein eingebluteter Bereich angeschnitten ist (Pfeil). Insgesamt lassen sich keine nennenswerten morphologischen Unterschiede zwischen den Subzellinien erkennen. Stern: Blutgefäß.1 $\times 10^{6}$ Zellen in $20 \mu \mathrm{l} \mathrm{Matrigel,} 4 \mathrm{~d}$ Inkubation, Bouin-fixiert, HE-gefärbt, Schnittdicke 3-4 $\mu \mathrm{m}$.

Im Vergleich zu diesen Ergebnissen zeigt Abbildung 3-10 die morphologischen Auffälligkeiten, die in der Zelllinie BL-2 nach LEF1-KD beobachtet werden konnten und auch in den medizinischen Doktorarbeiten von Stefan Ueberdiek (2016) und Pia Wilming (2017) beschrieben worden sind. Hier sind exemplarisch eine Kontrollzelllinie und ein Tumor mit reduzierter LEF1-Menge gegenübergestellt. Unter aberranter LEF1-Expression entwickelt sich ein dichterer Tumor (vergl. Abbildung 3-10 B und F), wobei die einzelnen Lymphomzellen keine Ausrichtung nach Blut- 
gefäßen erkennen lassen (Abbildung 3-10 C und D). Bei reduzierter LEF1-Menge zeigen sich dagegen zellärmere Tumoren, die außerdem das Phänomen der vessel co-option aufweisen, bei dem die Tumorzellen zu präexistenten Gefäßen migrieren und entlang dieser proliferieren. Diese vessel co-option ist in den Bildern $\mathrm{G}$ und $\mathrm{H}$ zu erkennen. Abgesehen von den histologischen Unterschieden zeigten LEF1-positive BL-2-Tumoren mehr Hämorrhagien als LEF1-reduzierte (Wilming 2017).
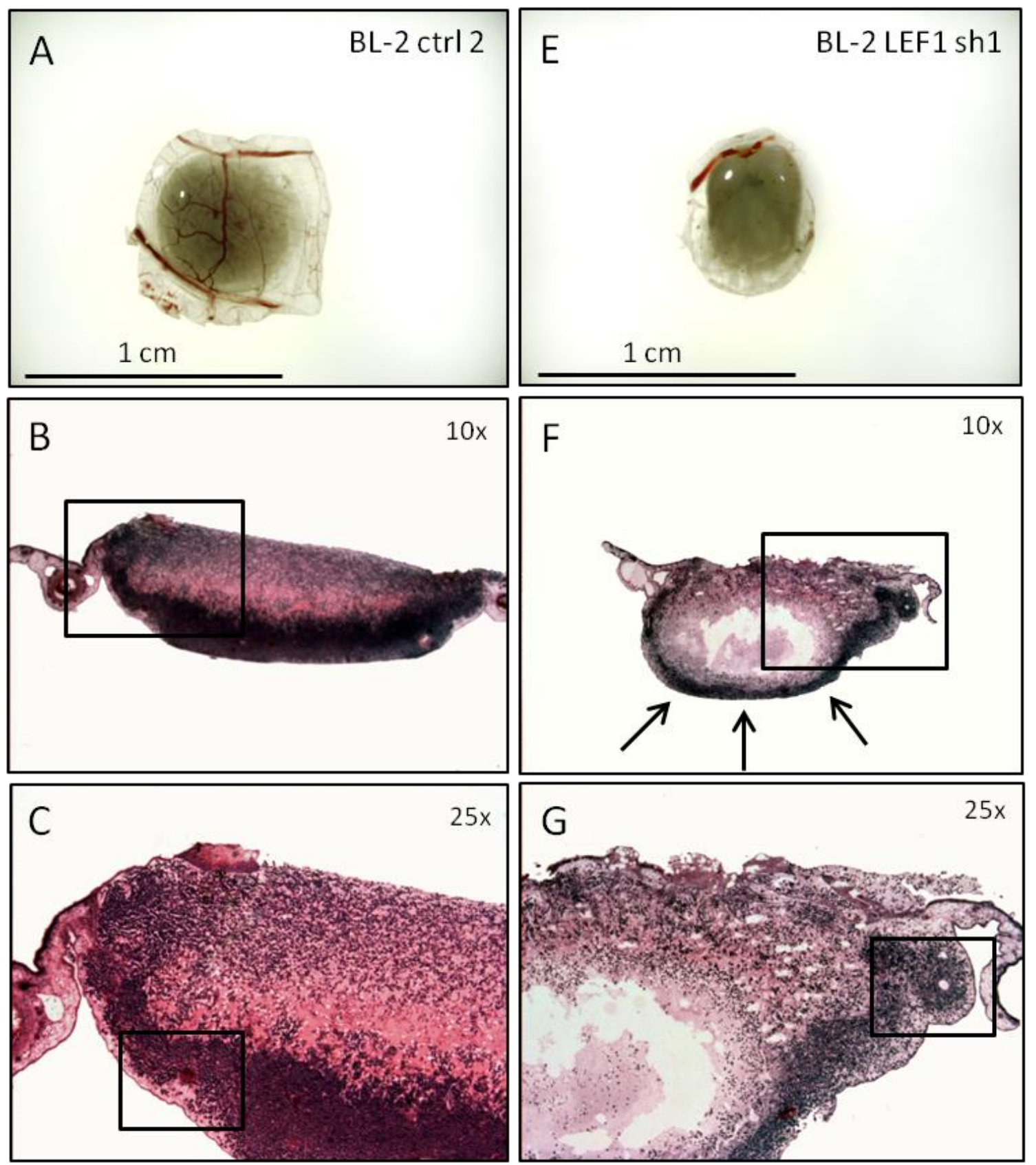

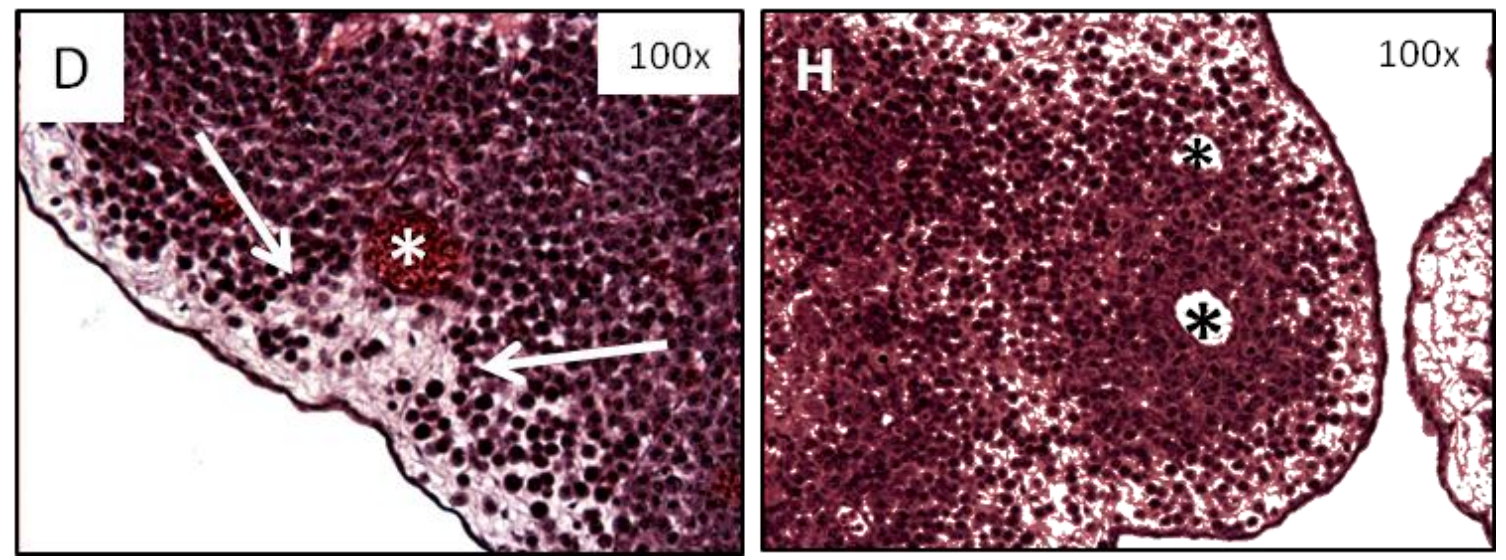

Abbildung 3-10: LEF1-KD führt im BL-2-CAM-Modell zu geringerer Tumorzelldichte und vessel co-option. BL-2-CAM-Tumoren mit LEF1-KD (E-H: BL-2 LEF1 sh1) weisen im Gegensatz zur Kontrollgruppe (A-D: BL-2 ctrl 2) eine geringere Tumorzelldichte, hauptsächlich Zellen als schmales Band im Tumorrandbereich (schwarze Pfeile, vgl. B und F) und eine Konzentration der Tumorzellen um Blutgefäße, die sog. vessel co-option, auf ( $G$ und $H)$. Die Zellen der Kontrolle zeigen dagegen keine besondere Affinität, die Gefäße zu umschließen, es ist sogar eine Aussparung zu sehen (weiße Pfeile in D). A und $E$ zeigen die entsprechenden nativen Tumoren, wobei die Kontrolle A eine stärkere Blutgefäßzeichnung aufweist. Stern: Blutgefäß. $2 \times 10^{6}$ Zellen in $20 \mu$ l Matrigel, $4 \mathrm{~d}$ Inkubation, Bouin-fixiert, HE-gefärbt, Schnittdicke 3-4 $\mu \mathrm{m}$.

Zusammenfassend lässt sich auch nach Variation der beimpften Lymphomzellzahl im BL-30-CAM-Modell kein Nachweis eines Einflusses von LEF1 auf die Tumormorphologie, Tumorgröße und das Vorkommen von hämorrhagischen Nekrosen finden. Hier unterscheidet sich die Zelllinie BL-30 eindeutig von Tumoren der Zelllinie BL-2.

\subsubsection{LEF1-knockdown beeinflusst die Tumormorphologie in BL-41-CAM- Tumoren}

Im CAM-Xenograft-Modell zeigten die Experimente mit den Zelllinien BL-2 und BL-30 unterschiedliche Ergebnisse in Bezug auf den LEF1-KD. Daher war das Testen einer weiteren Zelllinie unerlässlich. Es wurde die BL-Zelllinie BL-41 ausgewählt und erneut genetisch veränderte Klone mit stabilem LEF1-KD und entsprechende Kontrollen eingesetzt. In diesen Versuchen konnte nur eine KDZelllinie mit ausreichendem LEF1-KD zur Verfügung gestellt werden. Insgesamt wurden vier Zelllinien miteinander verglichen: der BL-41-Wildtyp, BL-41 LEF1 sh1 als LEF1-KD sowie BL-41 ctrl 1 und BL-41 ctrl 2 als scrambled-shRNAexprimierende Kontrollen. Der KD von LEF1 in der Zelllinie BL-41 LEF1 sh1 wurde 
mithilfe eines Immunoblots in Lysaten dieser Zelllinien vor jeder Beimpfung der Eier verifiziert (Abbildung 3-11).

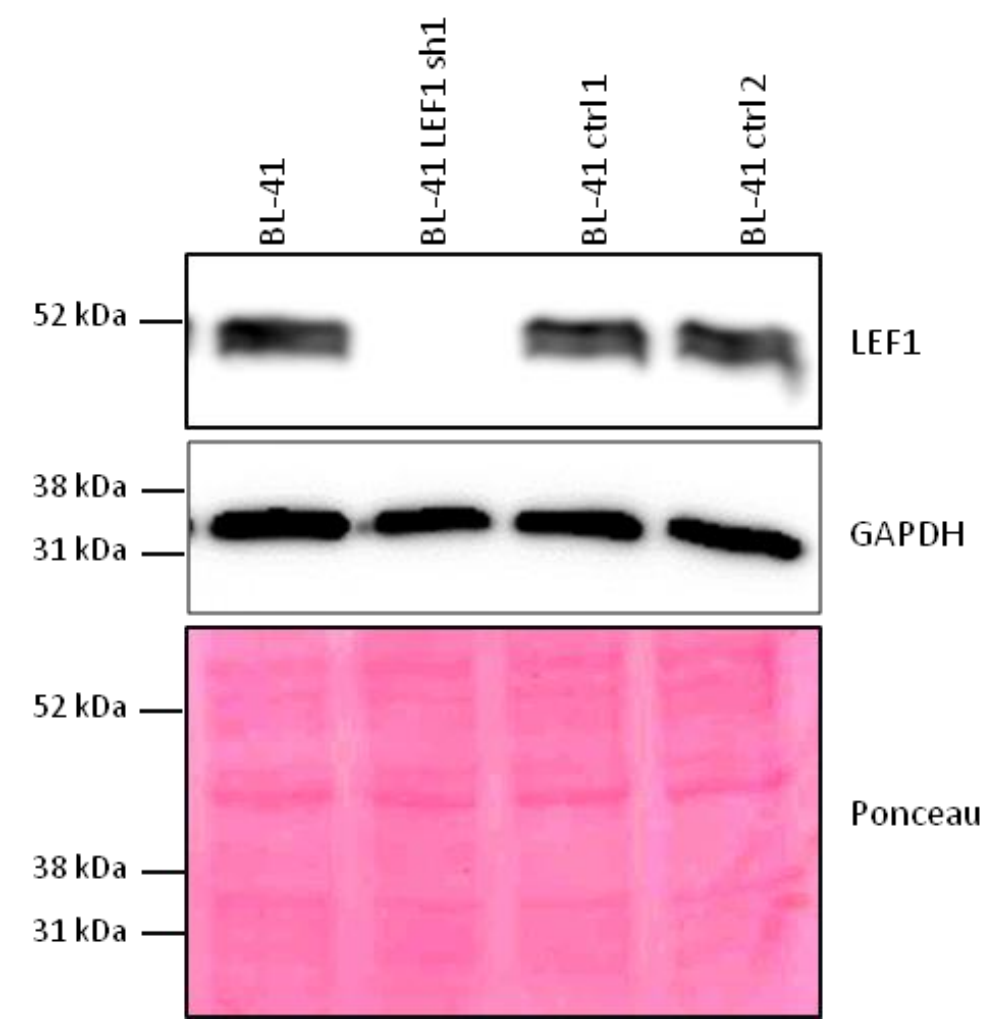

Abbildung 3-11: Repräsentativer Nachweis der LEF1-Expression in BL-41-Zellen. Die Abbildung zeigt vergleichende Immunoblotanalysen von BL-41-Zellen, in denen die LEF1-Proteinmenge nach LEF1-RNA-Interferenz vermitteltem KD reduziert wurde. Dargestellt sind die parentale BL-41Zelllinie sowie die LEF1-shRNA-exprimierende Subzelllinie BL-41 LEF1 sh1. Zum Vergleich dienen die scrambled-shRNA-exprimierenden Kontrollzellinien BL-41 ctrl 1 und BL-41 ctrl 2, die nicht an Sequenzen im humanen Genom binden können und somit auch keinen LEF1-KD verursachen. GAPDH und Ponceau-Färbung dienen als Beladungskontrollen. Auf der linken Seite der Abbildung sind die Proteinmassen entsprechend den genutzten Größenmarkern angegeben.

Außerdem wurde vor dem CAM-Versuch mithilfe einer FACS-Analyse der stabile Einbau des pGIPZ-Konstrukts in die transduzierten Zellklone überprüft sowie am Ende des CAM-Assays die GFP-Expression mittels Fluoreszenzmikroskopie dargestellt (Abbildung 3-12). Der GFP-Gehalt kann als Indikator für das Maß gesehen werden, in dem die transduzierte shRNA im Genom der Zellen abgelesen wird. 

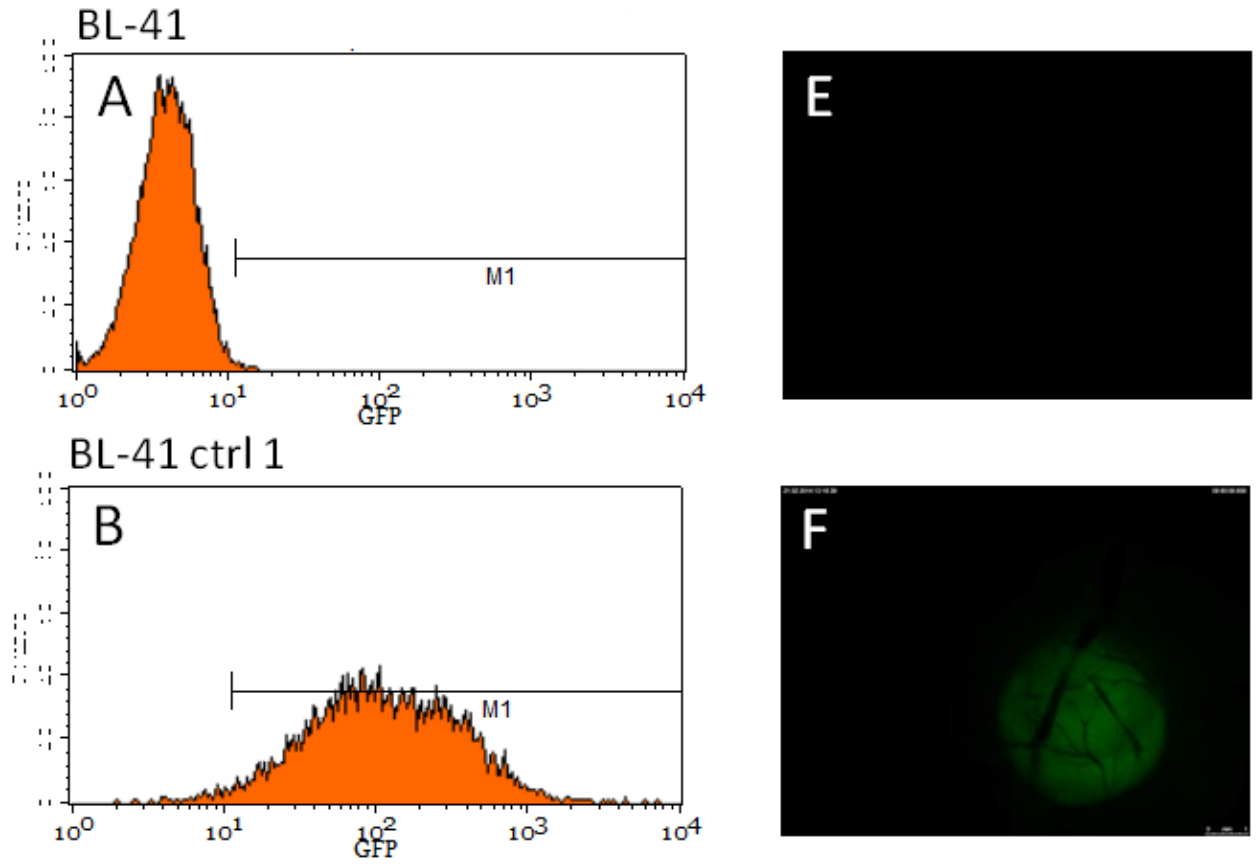

\section{$\mathrm{BL}-41 \mathrm{ctrl} 2$}
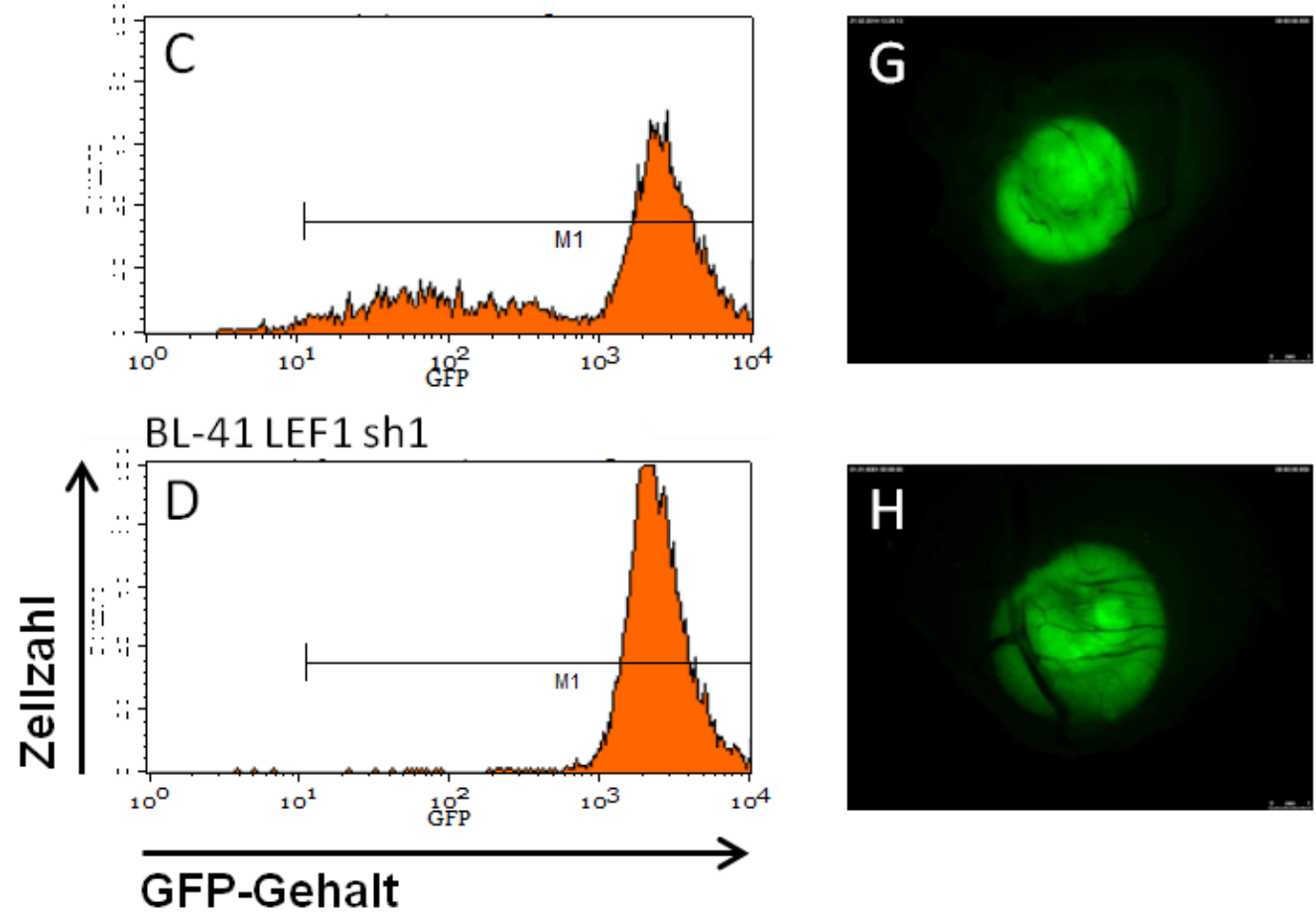

Abbildung 3-12: Detektion der GFP-Expression in den BL-41-Zelllinien mittels Durchflusszytometrie und in CAM-Tumoren durch Fluoreszenzmikroskopie. Die FACSAnalysen stellen die GFP-Fluoreszenz der viral transduzierten Zellen aufgetragen gegen die Zellzahl dar (A-D). Der Wildtyp BL-41 (A, E) ist genetisch unverändert und weist somit auch keine GFP-Fluoreszenz auf. Jeweils rechts der FACS-Analyse ist die Fluoreszenzaufnahme eines entsprechenden CAM-Tumors dargestellt $(\mathrm{E}-\mathrm{H})$. 
Für den CAM-Assay mit BL-41-Subzelllinien wurden 3 x $10^{6}$ Zellen auf die HühnerCAM aufgetragen. Tabelle 3-3 gibt eine Zusammenfassung der in zwei identischen CAM-Assays beimpften und geernteten Lymphome und in einer dritten Spalte die durchschnittliche Größe der Tumoren an. Es finden sich keine deutlichen Unterschiede zwischen den Zelllinien.

Tabelle 3-3: Zusammenfassung der BL-41-Tumoren. Gezeigt ist eine Übersicht aller geernteten BL-41-Präparate in zwei Replikaten und deren durchschnittliche Fläche. Angegeben ist die Anzahl der geernteten Tumoren, in Klammern die Zahl der initial beimpften Eier. $1 \times 10^{6}$ Zellen in $20 \mu \mathrm{l}$ Matrigel, $4 \mathrm{~d}$ Inkubation.

\begin{tabular}{|l|c|c|c|}
\hline \multirow{2}{*}{ Zelllinie } & \multicolumn{2}{|c|}{$\begin{array}{c}\text { Zahl der geernteten Tumoren an den } \\
\text { initial beimpften Eiern }\end{array}$} & $\begin{array}{c}\text { Mittelwert der Tumor- } \\
\text { flächen [cm }{ }^{2} \text { ] }\end{array}$ \\
\cline { 2 - 3 } & 1. CAM-Assay & 2. CAM-Assay & \\
\hline BL-41 & $6(8)$ & $9(9)$ & 0,117 \\
\hline BL-41 ctrl 1 & $7(8)$ & $8(8)$ & 0,130 \\
\hline BL-41 ctrl 2 & $6(8)$ & $8(8)$ & 0,139 \\
\hline BL-41 LEF1 sh1 & $5(9)$ & $12(12)$ & 0,116 \\
\hline
\end{tabular}

In Abbildung 3-13 sind die einzelnen Tumorgrößen graphisch aufgetragen. Zwischen den BL-41-Subzelllinien lassen sich in ovo keine signifikanten Unterschiede im Tumorwachstum feststellen.
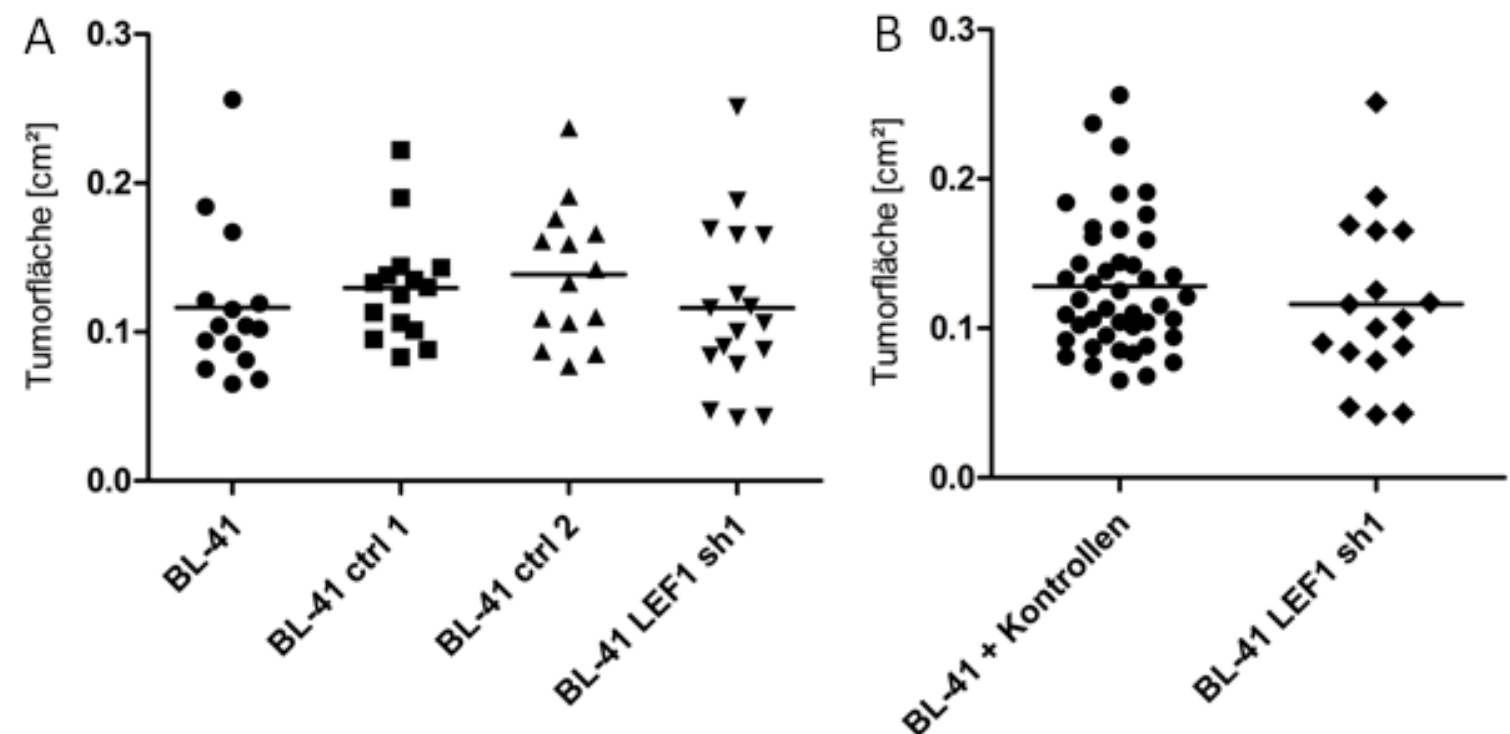

Abbildung 3-13: Größenvergleich der BL-41-CAM-Tumoren. In Grafik A sind die Größen der Tumoren in Form ihrer Fläche der einzelnen Zelllinien mit Mittelwert dargestellt. In Grafik B sind die 
aberrant LEF1-exprimierenden Zellen und die KD-Zelllinien zu jeweils einer Gruppe zusammengefasst. Es ergeben sich für beide Grafiken keine signifikanten Größenunterschiede. A: one-way ANOVA; $p<0,05$. B: T-Test; $p<0,05.3 \times 10^{6}$ Zellen in $20 \mu \mathrm{l}$ Matrigel, $4 \mathrm{~d}$ Inkubation.

Trotz einer aufgetragenen Zellzahl von $3 \times 10^{6}$ zeigten die 61 geernteten Tumoren kaum sichtbare hämorrhagische Nekrosen (insgesamt 5 von 61 Präparaten) und machten somit in diesem Aspekt auch keine LEF1-bezogene Auswertung möglich. Eine Übersicht der nativen Tumoren gibt Abbildung 3-14.
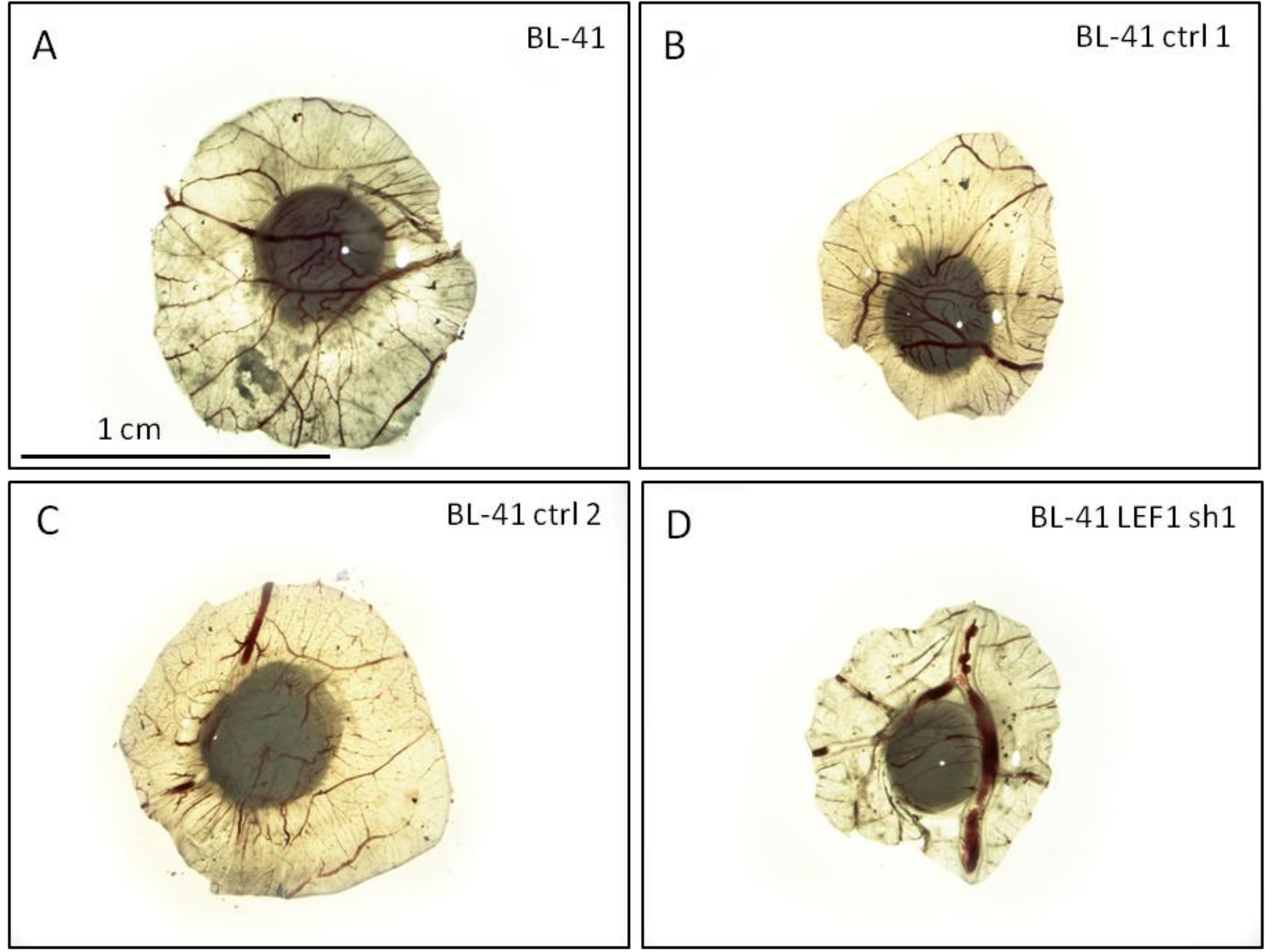

Abbildung 3-14: Repräsentative Auswahl der nativen BL-41-CAM-Tumoren. A-C zeigen die Zellinien mit aberranter LEF1-Expression, D die LEF1-KD-Zelllinie BL-41 LEF1 sh1. Die Tumoren aller B-41 Zelllinien verfügen nur in Ausnahmefällen über Einblutungen, die daher in diesen Fotos auch nicht zu sehen sind. $3 \times 10^{6}$ Zellen in $20 \mu \mathrm{l}$ Matrigel, $4 \mathrm{~d}$ Inkubation.

Auf mikroskopischer Ebene fanden sich jedoch systematische morphologische Besonderheiten: Im HE-Schnitt breiten sich die LEF1-exprimierenden Kontrollzellen und der BL-41-Wildtyp innerhalb des Tumors aus und zeigen keine besondere Affinität zu den Gefäßen (Abbildung 3-15 A-F). In Abbildung 3-15 G und H wird deutlich, dass sich die KD-Zellen im Gegensatz dazu meist am Tumorrand kon- 
zentrieren und dort ebenso wie die BL-2-KD-Tumoren eine Inanspruchnahme präexistenter Blutgefäße zeigen.
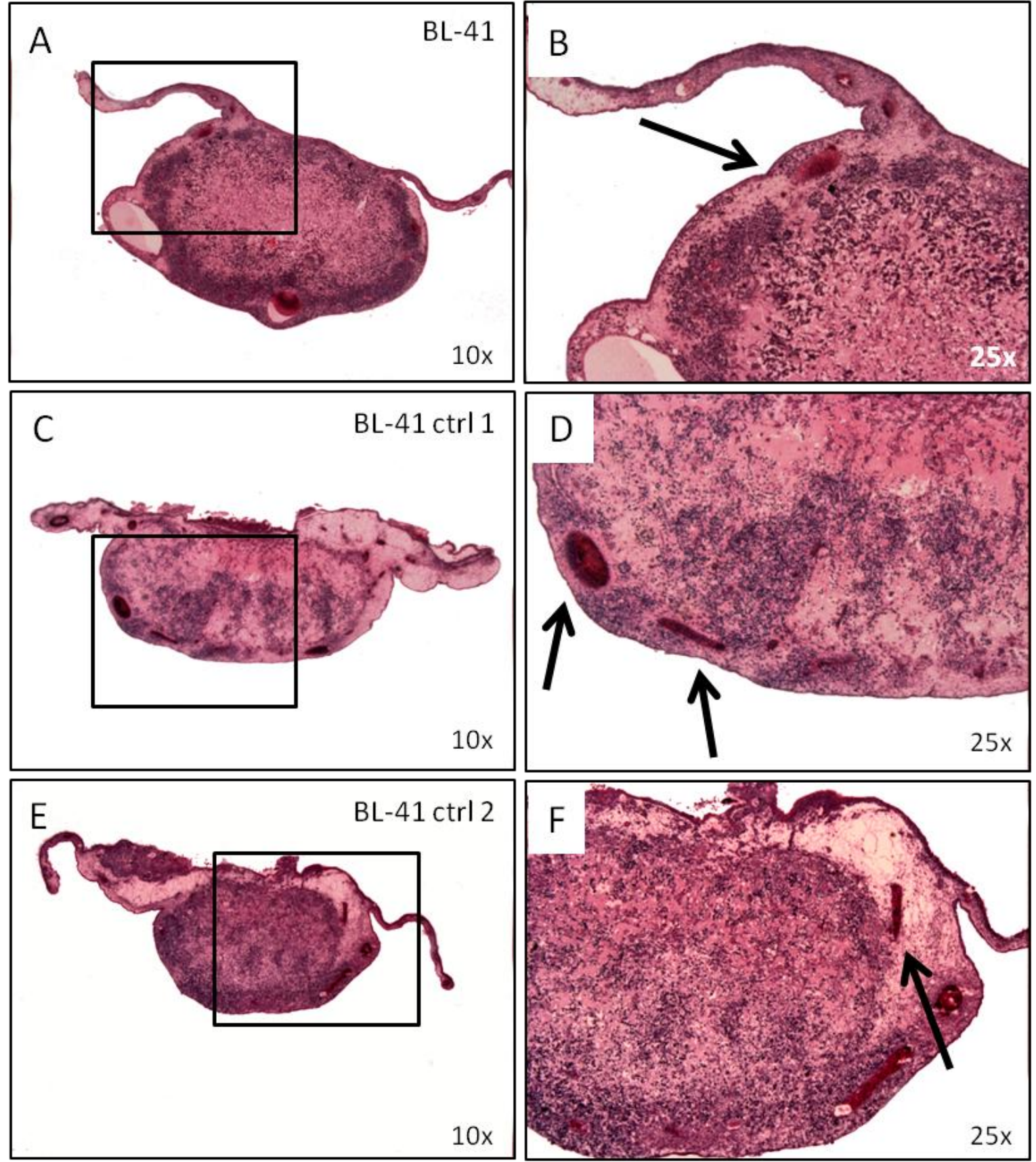

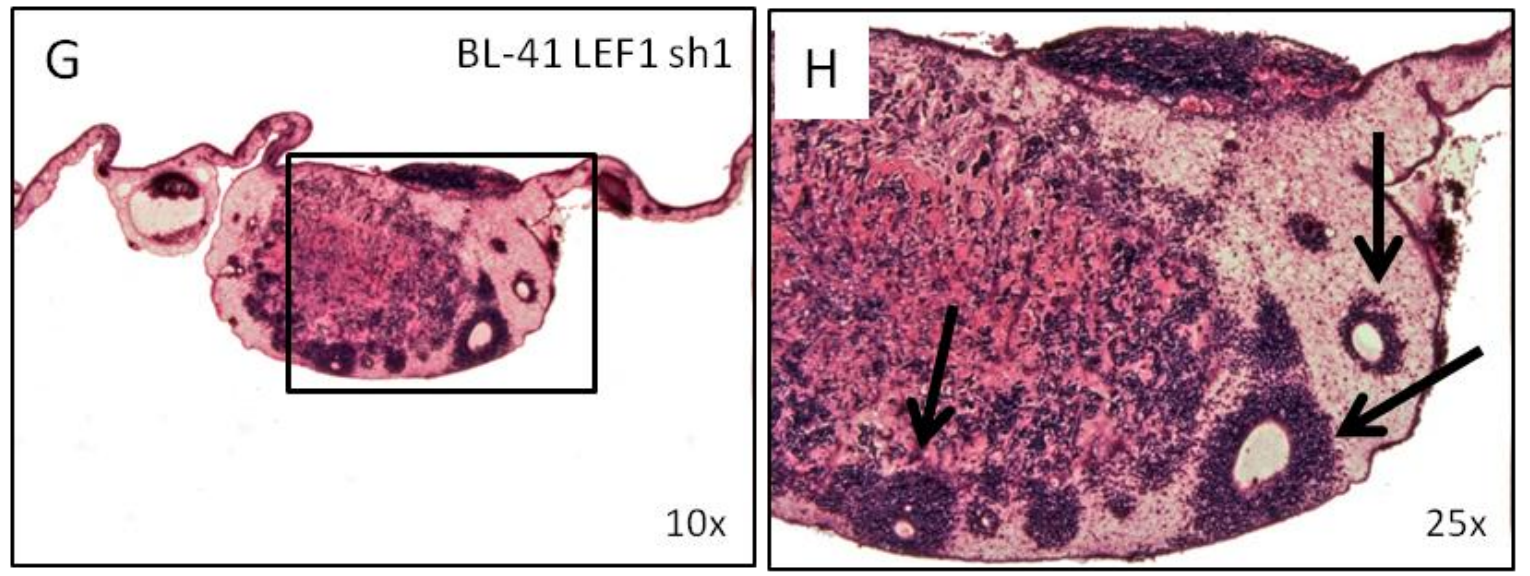

Abbildung 3-15: Repräsentative Auswahl von Tumorschnitten der vier BL-41-Subzelllinien. A und B zeigt einen Tumor der parenteralen BL-41, C und D die Kontrolle BL-41 ctrl 1, E und F BL-41 ctrl 2. In den Bildern $G$ und $H$ ist dazu im Vergleich ein Lymphom der KD-Zelllinie BL-41 LEF1 sh1 abgebildet. Rechts ist jeweils ein Ausschnitt aus der linken Übersichtsaufnahme dargestellt. Blutgefäße (Pfeile) werden bei aberranter LEF1-Expression nicht in besonderem Maße von Tumorzellen umrandet (B, D, F). LEF1-Defizienz führt dagegen zu vessel co-option und geringerer Tumorzelldichte: LEF1-defiziente Tumoren zeigen eine besondere Affinität zu Blutgefäßen und okkupieren diese in außergewöhnlichem Maße (Pfeile in H). $3 \times 10^{6}$ Zellen in $20 \mu \mathrm{l}$ Matrigel, $4 \mathrm{~d}$ Inkubation, Bouin-fixiert, HE-gefärbt, Schnittdicke 3-4 $\mu \mathrm{m}$.

Die vessel co-option bei KD-Tumoren ist in der folgenden Abbildung 3-16 genauer dargestellt. Die KD-Zellen migrieren auch aus dem Zellverband heraus zu weiter entfernten Gefäßen und umschließen diese vollständig (Abbildung 3-16 B und C). Dieses Phänomen konnte bei LEF1-exprimierenden CAM-Tumoren nicht beobachtet werden: Abbildung 3-17 stellt Gefäße im Tumorrandbereich LEF1positiver Neoplasien dar. Bei diesen werden die randständigen Gefäße nicht okkupiert. 

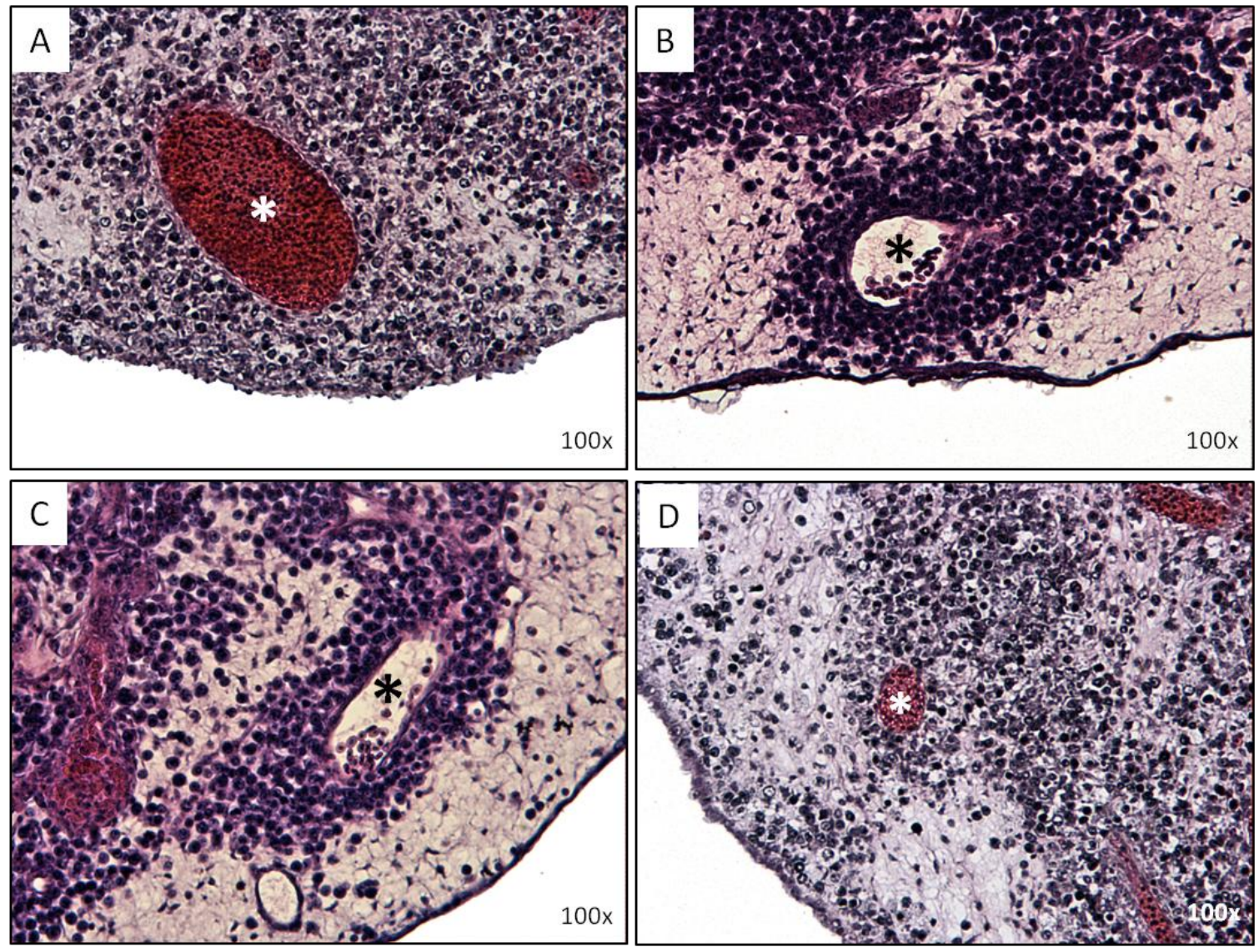

Abbildung 3-16: Vessel co-option bei In-ovo-Lymphomen der BL-41 nach LEF1-KD. In A-D sind exemplarisch Blutgefäße (Sterne) von Tumoren der Zelllinie BL-41 LEF1 sh1 abgebildet. Die Lymphomzellen vermehren sich in außergewöhnlichem Maße um die nährstoffspendenden Gefäße des Hühnerembryos und migrieren auch aus dem Zellverband zu entfernteren Gefäßen ( $B$ und $C$ ). $3 \times 10^{6}$ Zellen in $20 \mu \mathrm{l}$ Matrigel, $4 \mathrm{~d}$ Inkubation, Bouin-fixiert, HE-gefärbt, Schnittdicke 3-4 $\mu \mathrm{m}$. 

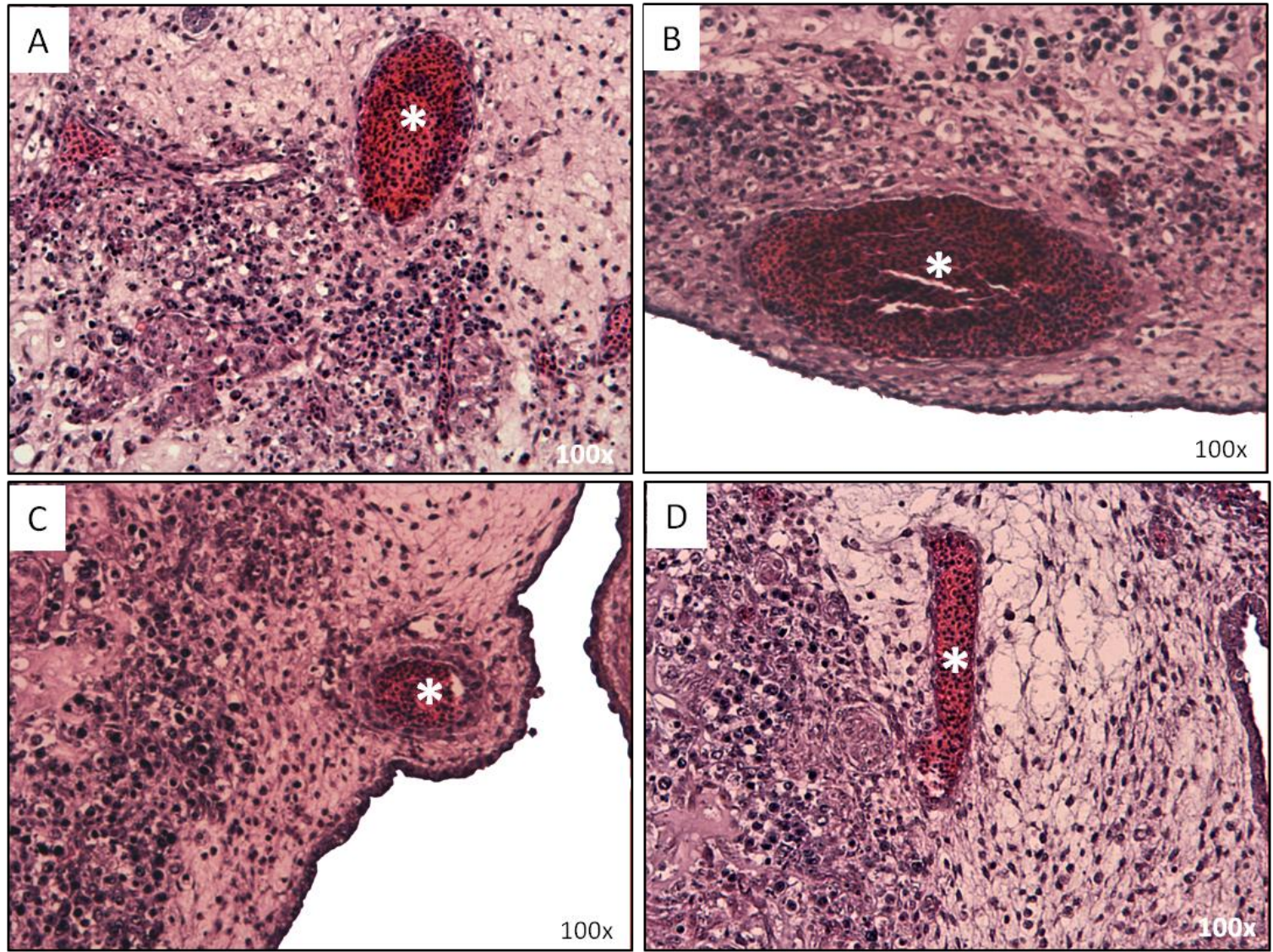

Abbildung 3-17: LEF1-exprimierende BL-41-Tumoren zeigen keine besondere Affinität zu Blutgefäßen. A: BL-41 ctrl 1, B-D: BL-41 ctrl 2. Stern: Blutgefäß. $3 \times 10^{6}$ Zellen in $20 \mu$ l Matrigel, 4 d Inkubation, Bouin-fixiert, HE-gefärbt, Schnittdicke 3-4 $\mu \mathrm{m}$.

Außerdem konnte eine weitere histologische Besonderheit der BL-41-Tumoren festgestellt werden. Diese zeigten nicht systematisch, aber morphologisch auffällig in einigen histologisch aufgearbeiteten Präparaten eine außergewöhnliche, teilweise wulstartig verdickte CAM. In diesen Neoplasien lässt sich nur eine geringe CAM-Tumor-Interaktion beobachten, häufig liegt das Zell-Matrigel-Gemisch nur auf der CAM auf, ohne in sie einzudringen. In Abbildung 3-18 wird deutlich, dass dieses Phänomen LEF1-unabhängig beobachtbar war. Teilweise wölbt sich die CAM von unten in den aufgetragenen Zelltropfen hinein (Abbildung 3-18 A und B). Die LEF1-KD-Tumoren mit dieser Konfiguration zeigten deutlich seltener eine vessel co-option. Dieses Erscheinungsbild bietet sich auch bei einer applizierten Zellzahl von $2 \times 10^{6}$, welches in Abbildung 3-19 an zwei parenteralen BL-41Tumoren verdeutlicht wird. 

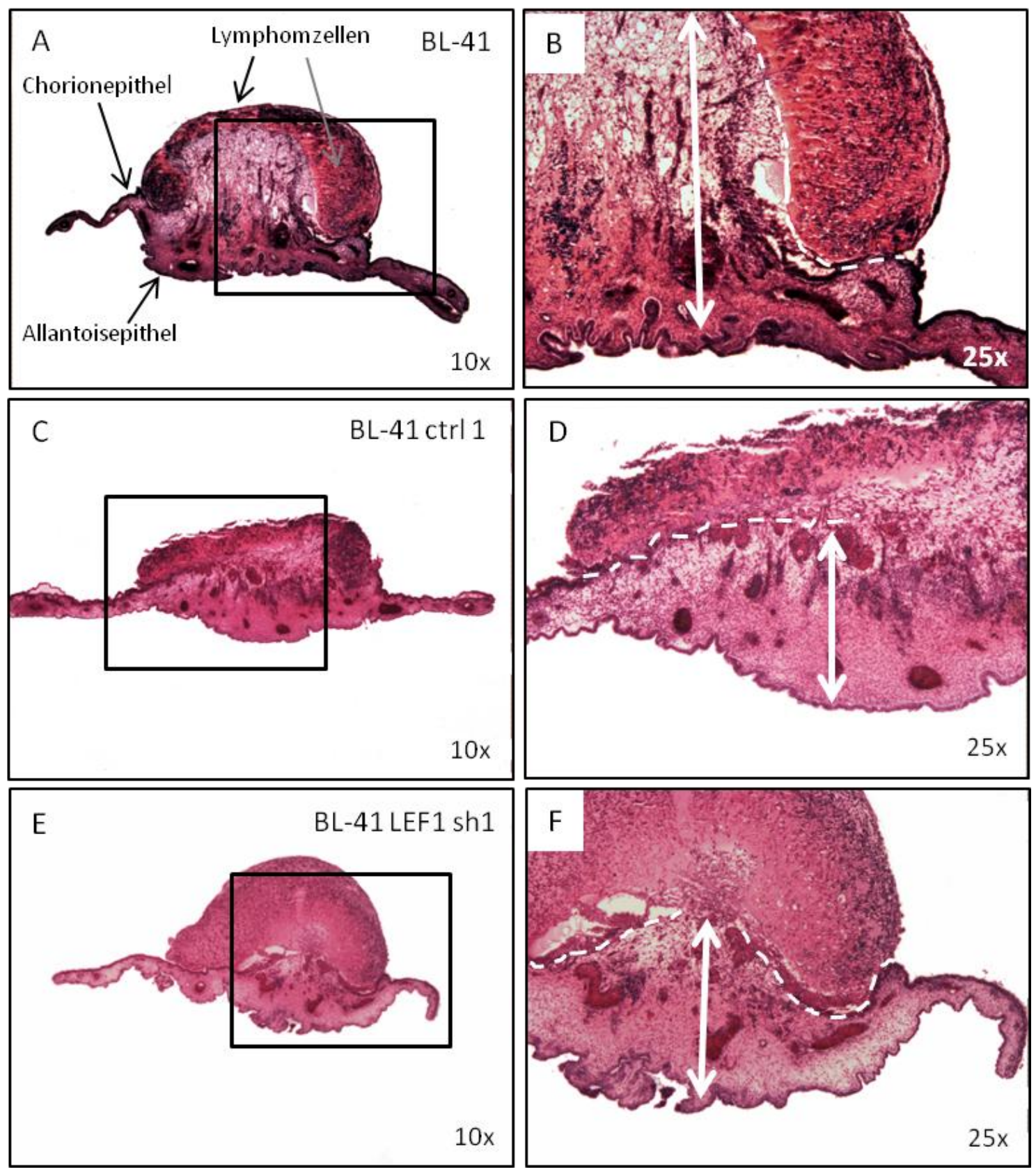

Abbildung 3-18: BL-41-Tumoren weisen als morphologische Besonderheit regelmäßig eine verdickte CAM auf. Nicht systematisch, jedoch morphologisch außergewöhnlich zeigen sich unabhängig vom LEF1-Status regelmäßig Neoplasien mit deutlich verdickter CAM (weißer Doppelpfeil). A-D stellen hier exemplarisch aberrant LEF1-exprimierende Tumoren und E-F einen Tumor mit reduzierter LEF1-Expression dar. In diesen Tumoren findet nur eine geringe Interaktion zwischen Tumorzellen und CAM-Gewebe statt, sodass sich hier nur selten kooptierte Gefäße finden. In $\mathrm{A}$ ist beispielhaft das Chorion- und Allantoisepithel beschriftet sowie das Lymphomzell-MatrigelGemisch bezeichnet, das in diesen Tumoren kaum in die CAM eindringt. Die Grenze zwischen Tumorzellen und CAM ist in den rechten Vergrößerungen $B, D$ und $F$ der linken Übersichtaufnahme markiert (weiß gestrichelte Linie). $3 \times 10^{6}$ Zellen in $20 \mu$ l Matrigel, $4 \mathrm{~d}$ Inkubation, Bouin-fixiert, HE-gefärbt, Schnittdicke 3-4 $\mu \mathrm{m}$. 

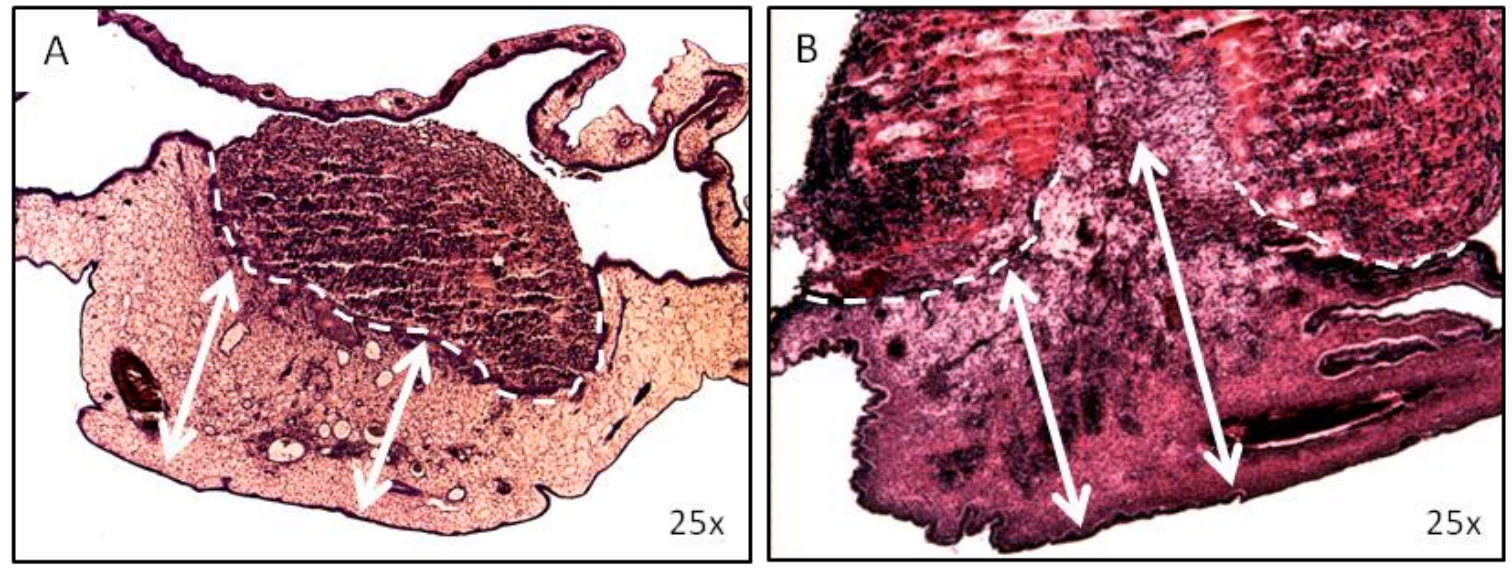

Abbildung 3-19: Eine verdickte CAM zeigt sich bei BL-41-Tumoren unabhängig von der applizierten Zellzahl. Abgebildet sind zwei exemplarische Tumoren der parenteralen Zelllinie BL-41. Auch nach Beimpfen mit $2 \times 10^{6}$ Zellen bildet sich regelmäßig eine auffällig verdickte CAM. Die Grenze zwischen CAM und Tumorzell-Matrigel-Gemisch ist durch die weiß gestrichelte Linie angedeutet. Die Doppelpfeile stellen die Dicke der CAM dar. In B wölbt sich die CAM mittig in den Lymphomzelltropfen. $2 \times 10^{6}$ Zellen in $20 \mu \mathrm{l}$ Matrigel, $4 \mathrm{~d}$ Inkubation, Bouin-fixiert, HE-gefärbt, Schnittdicke 3-4 $\mu \mathrm{m}$.

In Abbildung 3-20 ist links ein Foto des in Abbildung 3-18 A und B dargestellten parenteralen BL-41-Tumors mit auffälliger CAM abgebildet, daneben der BL-41Tumor aus Abbildung 3-15 A und B. Hier wird deutlich, dass diese besondere CAM-Konfiguration in der Hellfeldaufnahme nicht zu erkennen ist. Die beiden Tumoren zeigen ein sehr ähnliches Erscheinungsbild.
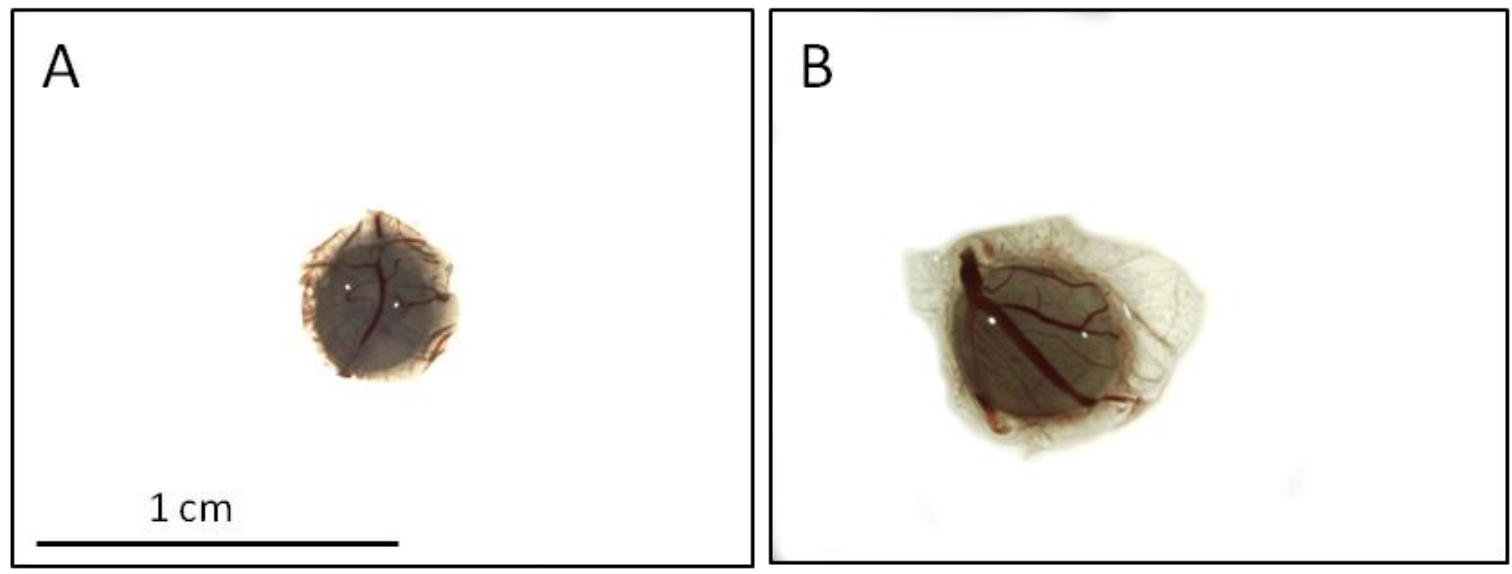

Abbildung 3-20: Vergleich zweier Hellfeldaufnahmen der BL-41-Tumoren. Es handelt sich um zwei parenterale BL-41-Neoplasien. A zeigt den Tumor mit auffälliger CAM, aus dem die histologischen Schnitte in Abbildung 3-18 A und B entstanden sind. In $B$ ist der Tumor aus Abbildung 3-15 A und B abgebildet, der eine reguläre CAM zeigt. In den Hellfeldaufnahmen unterscheiden 
sich Tumoren mit verdickter CAM nicht wesentlich von den restlichen BL-41-Tumoren. $3 \times 10^{6}$ Zellen in $20 \mu \mathrm{l}$ Matrigel, $4 \mathrm{~d}$ Inkubation.

Bis hierhin konnte festgestellt werden, dass die einzelnen Burkitt-LymphomZellinien unterschiedlich stark auf den LEF1-KD reagieren. Bei LEF1-Defizienz konnte in BL-2- und BL-41-CAM-Tumoren die sog. vessel co-option beobachtet werden. BL-2 LEF1-KD-Tumoren zeigten zudem signifikant mehr hämorrhagische Nekrosen (Wilming 2017). Im BL-30-Modell lässt sich dagegen nach LEF1-KD keine vessel co-option feststellen und auch die Größenanalyse zeigt hier ein von den Zelllinien BL-2 und BL-41 abweichendes Ergebnis.

\subsection{Vergleichende Analysen des Verhaltens der Burkitt- Lymphom-Zelllinien BL-2, BL-30 und BL-41 im CAM- Xenograft-Modell}

Die Gruppe der für die CAM-Studien verwendeten Burkitt-Lymphom-Zelllinien zeigte sich in den In-ovo-LEF1-Experimenten deutlich heterogener, als dies das In-vitro-Verhalten vermuten ließ. Aus diesem Grund wurden in den folgenden Analysen die parenteralen Zelllinien BL-2, BL-30 und BL-41 miteinander verglichen und dann das Wachstumsverhalten auf der CAM näher betrachtet.

Zunächst wurde die Proliferation der Zelllinien in vitro gemessen. Abbildung 3-21 verdeutlicht, dass sich die Proliferationsraten der BL-2, BL-30 und BL-41 unter Laborbedingungen nicht signifikant voneinander unterscheiden.
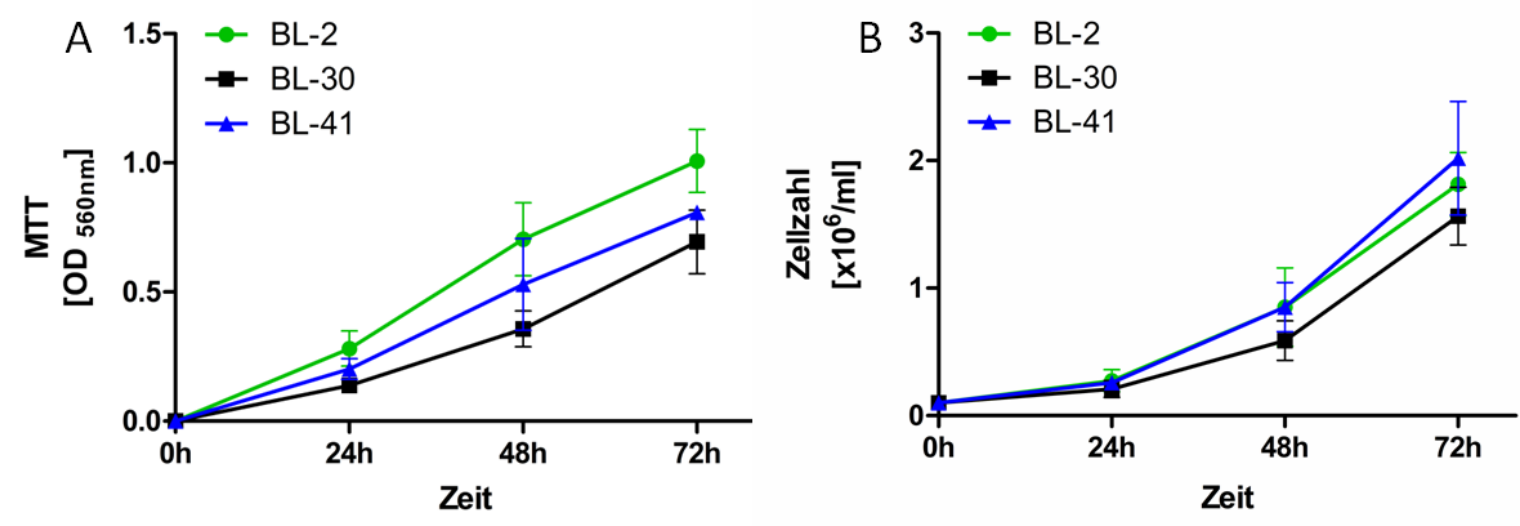

Abbildung 3-21: Die Zelllinien BL-2, BL-30 und BL-41 unterschieden sich in vitro nicht signifikant in ihrer Proliferation. Sowohl im MTT-Assay (A) als auch in der Bestimmung der Zellzahl 
(B) finden sich keine signifikanten Wachstumsdifferenzen. Begonnen wurde in beiden Fällen mit einer Zellkonzentration von $10^{5} / \mathrm{ml}$. MTT: $n=3$; Zellzahlbestimmung: $n=5$. +/- SD. One-way ANOVA: nicht signifikant bei $p<0,05$.

Im Gegensatz dazu zeigte sich auf der CAM ein völlig anderes Bild. Tabelle 3-4 gibt einen Überblick über die für diese Auswertung herangezogenen CAM-Assays und die Durchschnittsgröße der Tumoren. In diesem Kapitel wurden nur Tumoren von Eiern mit einer Anzahl von $2 \times 10^{6}$ beimpften Zellen ausgewertet.

Tabelle 3-4: Zusammenfassung der geernteten Tumoren. Gezeigt ist eine Übersicht über die Anzahl der geernteten BL-41-, BL-2- und BL-30-Präparate in bis zu vier Replikaten und deren durchschnittliche Größe. In Klammern ist die initial beimpfte Anzahl der Eier angegeben. $2 \times 10^{6}$ Zellen in $20 \mu$ l Matrigel, 4 d Inkubation.

\begin{tabular}{|c|c|c|c|c|c|}
\hline \multirow[t]{2}{*}{ Zelllinie } & \multicolumn{4}{|c|}{$\begin{array}{c}\text { Zahl der geernteten Tumoren an den initial beimpften } \\
\text { Eiern }\end{array}$} & \multirow{2}{*}{$\begin{array}{c}\text { Mittelwert der } \\
\text { Tumorflächen } \\
{\left[\mathrm{cm}^{2}\right]}\end{array}$} \\
\hline & 1. CAM-Assay & 2. CAM-Assay & 3. CAM-Assay & 4. CAM-Assay & \\
\hline BL-41 & - & $1(2)$ & $3(3)$ & $5(5)$ & 0,117 \\
\hline BL-2 & - & - & - & $4(5)$ & 0,155 \\
\hline BL-30 & $5(8)$ & $5(7)$ & - & $5(5)$ & 0,258 \\
\hline
\end{tabular}

In Abbildung 3-22 sind die Größen der einzelnen Tumoren mit ihrem Mittelwert dargestellt.

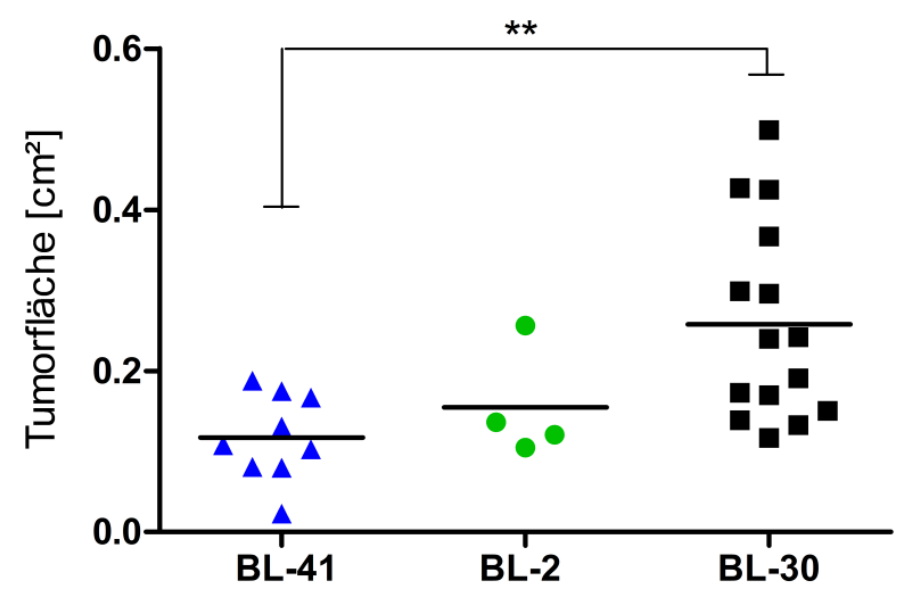

Abbildung 3-22: Größenunterschiede der BL-41-, BL-2- und BL-30-CAM-Tumoren. BL-41Neoplasien sind durchschnittlich am kleinsten, BL-30-Tumoren am größten. One-way ANOVA, ${ }^{* *} \mathrm{p}<0,01 ; 2 \times 10^{6}$ Zellen in $20 \mu \mathrm{l}$ Matrigel, $4 \mathrm{~d}$ Inkubation. 
Es wird deutlich, dass die BL-30 signifikant größere Tumoren auf der CAM bildet, als die Zelllinie BL-41. Der Mittelwert der Tumorfläche der BL-2-Neoplasien liegt zwischen den beiden anderen Zelllinien.

Darüber hinaus waren bei einigen Tumoren am noch nicht fixierten, frischen Präparat dunkle Einblutungen sichtbar (Abbildung 3-23). Bei der BL-30 fanden sich in 50 \% der Fälle solche hämorrhagischen Bereiche, bei BL-2-Tumoren in $25 \%$ und bei BL-41-Tumoren in keinem einzigen Präparat; die Unterschiede sind damit signifikant (Abbildung 3-24).
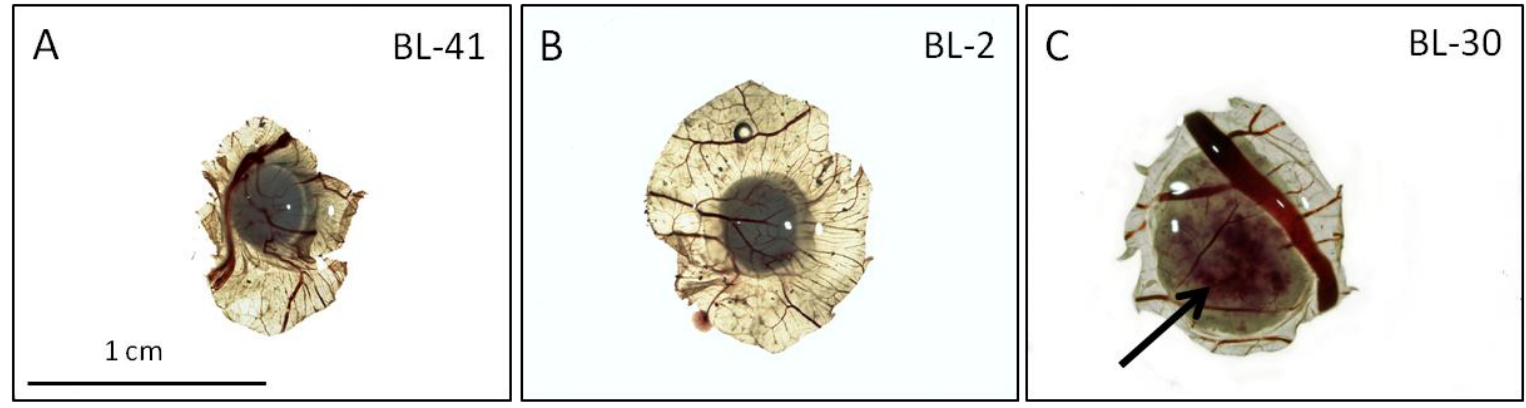

Abbildung 3-23: Repräsentative lichtmikroskopische Aufnahmen der extrahierten CAMTumor-Präparate. BL-41 (A) und BL-2 (B) sind sichtbar kleiner und zeigen nur selten Einblutungen. In $\mathrm{C}$ zeigt der Pfeil dagegen auf Hämorrhagien eines BL-30-Lymphoms. $2 \times 10^{6}$ Zellen in $20 \mu \mathrm{l}$ Matrigel, $4 \mathrm{~d}$ Inkubation.

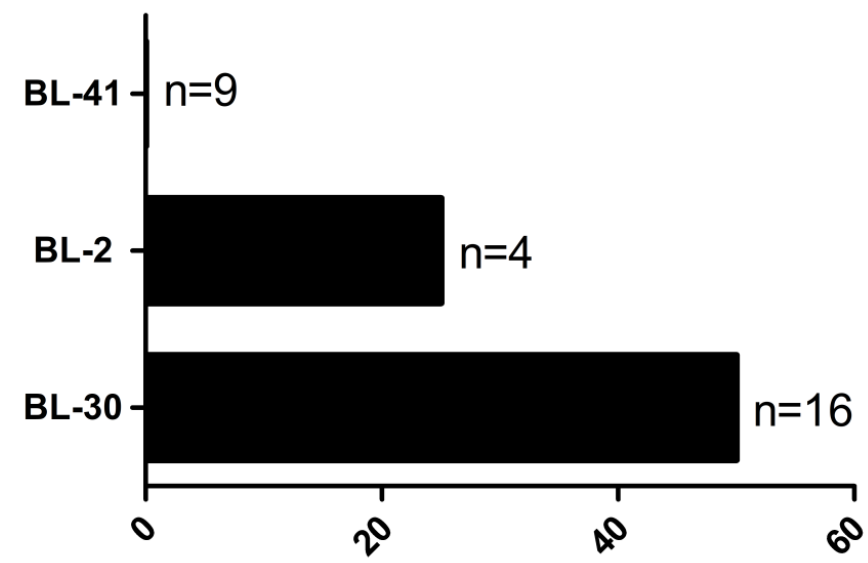

Anteil der hämorrhagischen Tumoren [\%]

Abbildung 3-24: Anteil der hämorrhagischen Tumoren an der Tumorgesamtzahl (n). Bei gleicher applizierter Zellzahl wiesen unter den Tumoren der BL-30 $50 \%$, der BL-2 $25 \%$ und der BL-41 $0 \%$ der Präparate Einblutungen auf. Die Zahl der Einblutungen ist damit signifikant abhängig von der Zelllinie. Exakter Test nach Fisher bei $p<0,05.2 \times 10^{6}$ Zellen in $20 \mu \mathrm{l}$ Matrigel, $4 \mathrm{~d}$ Inkubation. 
Tumorgröße und Hämorrhagien differieren demnach deutlich zwischen den Zelllinien. Analog zum Flächenunterschied verhielt es sich mit der im HE-Schnitt erkennbaren Tumorzelldichte bzw. dem noch sichtbaren Anteil an nicht verstoffwechseltem Matrigel. In Abbildung 3-25 wird deutlich, dass im BL-30Modell der Tumor gänzlich mit dicht gepackten Zellen ausgefüllt ist (C). Bei der Zelllinie BL-41 dagegen dominiert das noch sichtbare homogen eosinophile Matrigel in der mikroskopischen Aufnahme (A). Die Zelllinie BL-2 (B) liegt in Matrigelanteil und Zelldichte zwischen den beiden anderen Zelllinien (Abbildung 3-25).
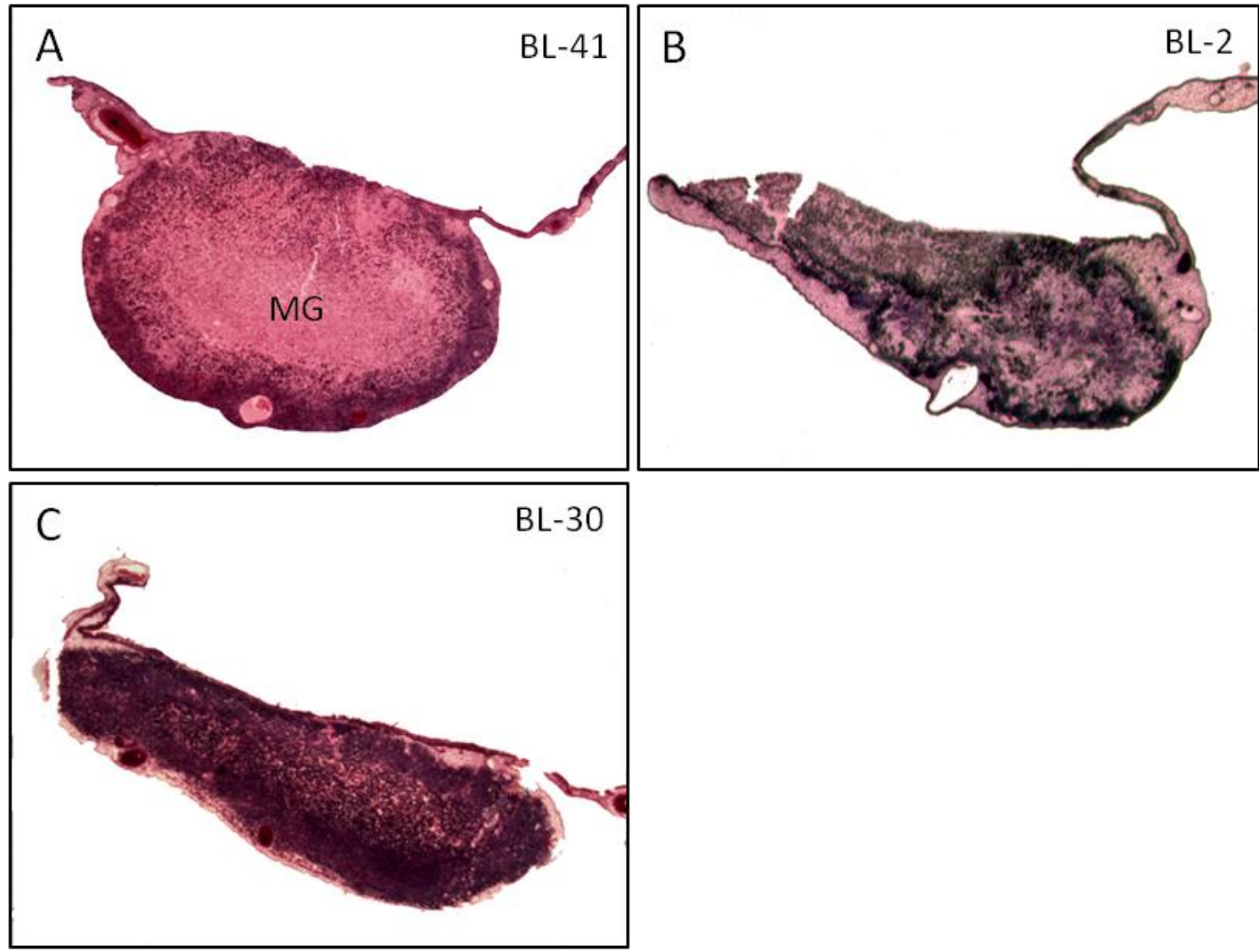

Abbildung 3-25: BL-41-, BL-2- und BL-30-CAM-Tumoren unterscheiden sich in ihrer mikroskopisch sichtbaren Zelldichte. Im Inneren des repräsentativen BL-41-Tumors (A) ist hauptsächlich unverdautes Matrigel (MG) zu erkennen, wohingegen der BL-30-Tumor (C) komplett mit Zellen ausgefüllt ist. MG: Matrigel; $2 \times 10^{6}$ Zellen in $20 \mu \mathrm{l}$ Matrigel, $4 \mathrm{~d}$ Inkubation, Bouin-fixiert, HEgefärbt, Schnittdicke 3-4 $\mu \mathrm{m}, 10$-fache Vergrößerung.

Die Analysen zeigen, dass die Zelllinie BL-30 auf dem Ei das aggressivste Wachstum entwickelt. Woran könnte das liegen? In Kapitel 3.1.2 wurde bereits die wie- 
derkehrend sichtbare CAM-Verdickung der BL-41-Tumoren erwähnt. Während nach dem Auftragen von BL-2- und BL-30-Zellen die CAM ihren gewöhnlichen dreischichtigen Aufbau mit einer innen liegenden dünnen Schicht aus lockerem mesenchymalen Bindegewebe aufweist, war diese Schicht bei den BL-41Lymphomen häufig, aber nicht systematisch stark vergrößert (vgl. Kapitel 3.1.1 und 3.1.2). Bei diesen Tumoren infiltrierte der die Lymphomzellen enthaltende Matrigel-Tropfen die CAM meist nur geringfügig. Bei den anderen beiden Zelllinien hingegen ist der applizierte Zell-Matrigel-Tropfen in annähernd $100 \%$ der ausgewerteten Proben vollständig in die CAM eingedrungen. Die CAM selbst zeigte sich dort als dünne dreischichtige Membran.

Zusammenfassend betrachtet scheinen sich die verwendeten BL-Zelllinien auf der CAM in Bezug auf Größe, Zelldichte, Einblutungen, Reaktion der CAM und das Vermögen, in sie einzudringen, sehr unterschiedlich zu verhalten. Aus BL-30Zellen entstehen dabei die größten, dichtesten und am häufigsten über hämorrhagische Nekrosen verfügenden Tumoren. Die CAM-Neoplasien der BL-41 sind am kleinsten, die Zellen am lockersten verteilt und verfügen in der Regel über keine Einblutungen. Der Matrigel-Zelltropfen hat gelegentlich Schwierigkeiten, überhaupt in die CAM einzudringen. Die sonst dünne CAM zeichnet sich bei den BL-41Neoplasien durch eine wiederkehrende wulstartige Verdickung aus. Die Tumoren der BL-2 befinden sich stets im Mittelbereich.

\subsubsection{MMP2 und MMP9 als mögliche Effektoren der Burkitt-Lymphom- Heterogenität im CAM-Modell}

Die bis hierhin festgestellte Heterogenität der getesteten Burkitt-LymphomZelllinien BL-2, BL-30 und BL-41 muss sich in der differenten Ausstattung mit bestimmten Proteinen widerspiegeln. Aufgrund der unterschiedlich starken Ausbreitung auf der CAM, der Diversität der Endothelpermeabiliät und nicht zuletzt wegen des unterschiedlichen Potentials der Lymphomzellen, in die CAM einzudringen, lag hier die Vermutung nahe, dass für diese Prozesse Metalloproteasen eine Rolle spielen könnten.

Im Folgenden wurden Überstände der drei Zellinien auf die MatrixMetalloproteasen 2 und 9 hin mittels Zymographie untersucht. Es stellte sich dabei 
heraus, dass die Aktivität der durch die BL-Zellen sezernierten MMPs nicht wesentlich über die Aktivität des durch das FCS in dem Medium ohnehin enthaltenen MMPs hinaus geht (Abbildung 3-26). Eine Kultivierung der BL-Zellen ist serumfrei leider nicht möglich (Zander und Bemark 2008).

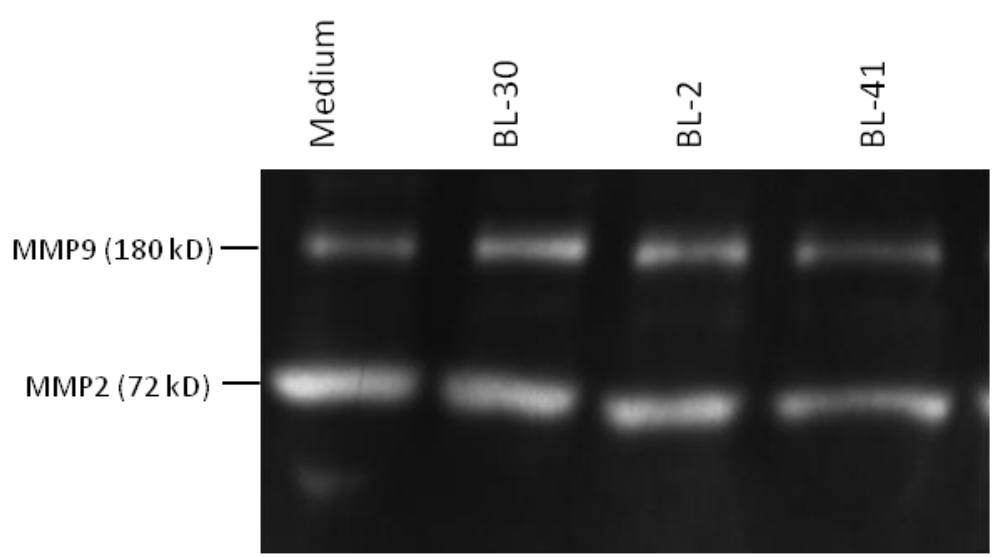

Abbildung 3-26: Repräsentatives Zymogramm konditionierter Medien von BL-30, BL-2 und BL-41. Die konditionierten Medien zeigen keine sichtbar höhere Aktivität an MMP2 und MMP9 als die Eigenaktivität des Serum-enthaltenden Mediums.

Zumindest die beiden hier untersuchten MMPs sind demnach mithilfe der Zymographie nicht eindeutig als Ursache für die Unterschiede der BL-Zelllinien im CAM-Assay zu identifizieren. 


\section{Diskussion}

Ziel dieser Arbeit war es, die pathophysiologische Bedeutung des Transkriptionsfaktors LEF1 in verschiedenen Burkitt-Lymphom-Zelllinien näher zu charakterisieren, um LEF1 in Zukunft als möglichen diagnostischen und prognostischen Marker zu nutzen oder spezifische Therapien zu entwickeln, die auf dem Verständnis der molekularen Ursache des Burkitt-Lymphoms basieren.

In der medizinischen Dissertation von Pia Wilming (2017) konnte bereits ein Einfluss von LEF1 auf die Angiogenese im BL-2-CAM-Xenograft-Modell festgestellt werden. Darauf aufbauend sollte in dieser Arbeit geklärt werden, inwieweit sich dieser Effekt auch in anderen Burkitt-Lymphom-Zelllinien findet, oder ob es sich lediglich um eine BL-2-spezifische Auswirkung handelt.

In einem weiteren Schwerpunkt wurde die Vergleichbarkeit einiger BL-Zelllinien an sich beleuchtet. Hierbei sollte insbesondere deren Wachstumsverhalten auf der CAM charakterisiert und die Zelllinien auf eventuelle Unterschiede in der MMPAktivität hin untersucht werden.

Es konnten zwei wichtige Ergebnisse herausgestellt werden:

I. Während sich die Zelllinien BL-2, BL-30 und BL-41 in vitro vergleichbar verhalten, unterscheiden sie sich in ovo in Bezug auf Tumorgröße, Hämorrhagien, Zelldichte und Tumormorphologie erheblich.

II. In CAM-Tumoren der Zellinie BL-41 und BL-2 kann nach LEF1-KD eine vermehrte Inanspruchnahme präexistenter Blutgefäße beobachtet werden, die als vessel co-option angesehen werden kann.

Im ersten Punkt wird deutlich, dass die Gruppe der Burkitt-Lymphome heterogener zu sein scheint, als bisher angenommen. Besonders die Zelllinie BL-30 fällt durch ein aggressives Wachstumsverhalten auf. Sie bildet im Vergleich zur BL-41 und BL-2 die größten, dichtesten und am häufigsten eingebluteten Tumoren. Die zahlreichen Hämorrhagien könnten als Hinweis auf eine gesteigerte Gefäßpermeabilität in Tumoren dieser Zelllinie gesehen werden. Im Gegensatz dazu zeigen sich in den signifikant kleineren Tumoren der Zelllinie BL-41 nur in Ausnahmefällen Ein- 
blutungen. Hier haben die Lymphomzellen sogar regelmäßig Schwierigkeiten, überhaupt durch das Chorionepithel in die CAM einzudringen.

Einen Hinweis auf Ursachen der unterschiedlichen Tumorentwicklung auf dem Ei könnte die Beobachtung der speziellen CAM-Konfiguration bei BL-41-Tumoren bieten. Die mitunter sichtbar verdickte CAM könnte eine Reaktion des sich entwickelnden Immunsystems des Hühnerembryos auf die wirtsfremden Zellen darstellen. In BL-2-CAM-Tumoren sind bereits Granulozyten, Makrophagen und dendritische Zellen als Zeichen einer aktiven Immunantwort des Hühnerembryos nachgewiesen worden (Klingenberg et al. 2014). Daraus ergibt sich als möglicher Erklärungsansatz, dass BL-41-Zellen im Gegensatz zu BL-2- und BL-30-Zellen eine stärkere Abwehrreaktion des Hühnerembryos hervorrufen könnten und sich daher kleinere Tumoren ohne Einblutungen, dafür aber mit reaktiv verdickter CAM entwickeln. In diesem Zusammenhang könnten immunhistochemische Färbungen näheren Aufschluss bringen. Eine alternative Hypothese ist, dass die BL-41-Zellen das Chorionepithel weniger effektiv durchdringen können als BL-30 und BL-2.

Neben der seit über 30 Jahren bekannten Ig/MYC-Translokation sind weitere genetische Besonderheiten vonnöten, damit ein hoch aggressives BL entsteht. Verschiedene Gensequenzierungen an BL-Proben zeigten bis zu 70 regelmäßig mutierte Gene, darunter ID3, GNAI3, RET, PIK3RI und ARIDIA (Love et al. 2012). Aber auch Mutationen im Transkriptionsfaktor TCF-3 sind möglich, der ein weiterer zentraler Schlüsselmediator in der Pathogenese des BL zu sein scheint (Schmitz et al. 2012). ID3 stellt physiologischerweise einen negativen Regulator von TCF-3 dar, welcher wiederum über die Aktivierung von Zyklin D3 den Übergang der G1zu S-Phase im Zellzyklus vermittelt und damit proliferationsfördernd wirkt (Schmitz et al. 2014). Loss-of-function-Mutationen im ID3-Gen finden sich in 34-68 \% der BL, Mutationen, die zu einer Aktivitätssteigerung von TCF-3 und Zyklin D3 führen, in $11 \%$ und $38 \%$ der Fälle (Love et al. 2012; Richter et al. 2012; Schmitz et al. 2012). Diese Beispiele an möglichen Mutationen sollen zeigen, dass sich die $\mathrm{Pa}-$ thogenese des BL nicht auf einzelne Faktoren beschränken lässt, die in jedem BL zu finden sind. Vielmehr gibt es eine große Anzahl an genetischen Veränderungen, die mit einer unterschiedlichen Wahrscheinlichkeit in den einzelnen $B L$ gefunden werden können. Dementsprechend können die Größenunterschiede zwi- 
schen BL-30 und BL-41 in ovo auch in einem differierenden Mutationsstatus begründet sein, dessen Auswirkungen sich in vitro nicht bemerkbar machen. Der Mutationsstatus der Zelllinien müsste in Zukunft durch entsprechende nextgeneration-sequencing-Analysen aufgeklärt werden. Aktuell sind in öffentlichen Datenbanken keine Daten für alle Zelllinien verfügbar. Für die BL-2 sind entsprechende Analysen von Richter et al. 2012 publiziert worden.

Durch dieses nicht einheitliche Wachstumsverhalten auf der Hühner-CAM ist auch die Beurteilung der In-ovo-Versuche mit LEF1-KD-Zelllinien erschwert. In zwei von drei BL-Zelllinien zeigten sich aber nach LEF1-KD eindeutig reproduzierbare morphologische Besonderheiten und deckten sich damit mit den bisherigen Beobachtungen: In wiederholten CAM-Versuchen mit aberrant LEF1-exprimierenden und LEF1-KD-Subklonen der Zelllinie BL-2 sowie analog dazu mit der Zelllinie BL-41, ließen sich im HE-Schnitt der LEF1-KD-Tumoren eine geringere Tumorzelldichte und vessel co-option erkennen. Die vessel co-option legt die Vermutung nahe, dass LEF1-reduzierte BL-2- und BL-41-Zellen stärker auf die Versorgung mit Nährstoffen aus dem Blutkreislauf des Hühnerembryos angewiesen sind, da das microenvironment hierzu nicht ausreicht. Eine weitere Möglichkeit besteht in einer geringeren Hypoxietoleranz der LEF1-defizienten Lymphomzellen. Dadurch könnte gleichzeitig die besonders im gefäßarmen Tumorinneren auffallende geringere Zelldichte mit begünstigt werden. Auch ein unterschiedliches Vermögen, Neoangiogenese zu betreiben, stellt hier einen schlüssigen Interpretationsansatz dar: Weniger nährstoff- und sauerstofftransportierende Gefäße bei LEF1-Defizienz könnten zu geringerer Proliferation und Konzentration der Lymphomzellen um präexistente Blutgefäße führen. Diese These wird durch Untersuchungen mit der Endothelzelllinie HUVEC gestützt, die zeigten, dass die Endothelzellen durch den Anreiz der konditionierten Medien LEF1-exprimierender BL-2-Zelllinien stärker migrieren als mit konditionierten Medien der KD-Zelllinien (Wilming 2017).

Aberrant LEF1-exprimierende BL-2- (Wilming 2017) und BL-41-CAM-Tumoren unterscheiden sich in ihrer Größe in Form der Fläche nicht von den KD-Tumoren. Aus dieser Beobachtung könnte man schließen, dass es keinen Nachteil für die KD-Tumoren gibt. In der Zellinie BL-30 entwickelten sich unter LEF1-KD sogar signifikant größere Tumoren. Einschränkend muss aber angemerkt werden, dass 
dieser Unterschied insbesondere durch die im Vergleich zur parenteralen BL-30 kleineren Kontrollen bedingt ist. Zwischen parenteraler BL-30 und den KDTumoren ergab sich kein signifikanter Größenunterschied, weshalb hier keine abschließende Beurteilung möglich ist. Die vessel co-option und die zumindest in der Zelllinie BL-2 seltener auftretenden Einblutungen sprechen insgesamt aber eindeutig für einen Vorteil bei LEF1-Expression. Es ist aber auch denkbar, dass eventuelle Größenunterschiede durch die individuelle Form des jeweiligen Tumors maskiert werden: Die Größe der Tumoren wurde in Form ihrer einnehmenden Fläche von lichtmikroskopischen Aufsichtsaufnahmen berechnet. Genauer, aber aufwendiger wäre es, dass Volumen zu ermitteln, um rundere Tumoren nicht fälschlicherweise als kleiner zu betrachten. Mit den untersuchten Parametern konnten letztendlich keine eindeutigen Größenunterschiede ermittelt werden.

Die geringere Zelldichte in Tumoren mit LEF1-KD, die in dieser Arbeit in den Zelllinien BL-2 und BL-41 beobachtet wurde, lässt dennoch die Vermutung zu, dass LEF1 an Prozessen der Zellteilung beteiligt ist. In Vorarbeiten der Arbeitsgruppe Prof. Dr. Kube konnten im In-vitro- ${ }^{3} \mathrm{H}$-Thymidin-Inkorporations-Assay keine signifikanten Proliferationsunterschiede zwischen den einzelnen Subklonen der verschiedenen verwendeten Zelllinien festgestellt werden. Auch die Proliferationsanalysen, die in dieser Arbeit zu den parenteralen Zelllinien durchgeführt wurden, ergaben keine signifikanten Diskrepanzen. Um einen direkten Proliferationsvorteil in ovo durch die LEF1-Expression zu validieren, wären weitere Versuche sinnvoll, wie beispielsweise die Quantifizierung der in einem Tumorschnitt tatsächlich erhaltenen Zellzahl.

Ein positiver Einfluss von LEF1 auf die Zellproliferation ist bereits beim Nierenzellkarzinom bekannt: Zellen mit hoher LEF1-Expression zeigten hier signifikant höhere Proliferationsraten als solche mit einem niedrigen LEF1-Expressionslevel (Shang et al. 2014). Shang et al. (2014) fanden ferner, dass dies im Nierenzellkarzinom durch die Unterdrückung des G2/M-Zellzyklusarrestes geschieht. Auch Ergebnisse von Wang et al. (2013b) im Maus-Xenograft-Modell mit Kolonkarzinomzellen belegen eine Hemmung des Tumorwachstums bei LEF1-KD. Ein weiteres Beispiel ist die Überexpression von LEF1 im Prostatakarzinom, die über eine ver- 
mehrte Androgenrezeptor-Expression ebenfalls zu einem gesteigerten Tumorwachstum und erhöhter Invasivität führt (Li et al. 2009).

Der Effekt des LEF1-KD im CAM-Modell war nicht konsistent in allen BL-Zelllinien nachweisbar. Die Subklone mit LEF1-KD der Zelllinie BL-30 zeigten weder eine klassische vessel co-option, noch waren Unterschiede in Hämorrhagien oder Zelldichte erkennbar. Die BL-30-Tumoren waren unabhängig vom LEF1-Status durch eine hohe Zelldichte und ausgeprägte Einblutungen gekennzeichnet. Auch nach Reduktion der aufgetragenen Zellzahl um $50 \%$ änderte sich dieses Ergebnis nur geringfügig. Es besteht die Möglichkeit, dass durch den LEF1-KD bedingte morphologische Unterschiede trotz der Zellreduktion noch immer durch das ausgeprägte Wachstum maskiert werden. Die BL-30-Zellen könnten auch von vorneherein durch einen sich unterscheidenden Mutationsstatus ein weitaus aggressiveres Wachstumsmuster aufweisen, das hier weniger stark als bei den anderen beiden Zellinien LEF1-abhängig ist. Um eventuelle doch maskierte Effekte aufzudecken, könnte in zukünftigen Experimenten die applizierte Zellzahl der BL-30-Subklone weiter reduziert werden.

Insgesamt ließ sich nur in zwei von drei getesteten BL-Zelllinien im CAM-Modell ein Einfluss des LEF1-KD auf Tumorzelldichte und eine von Blutgefäßen abhängige Organisation der Lymphomzellen nachweisen. Um diesen Einfluss eindeutig zu verifizieren, sollte in zukünftigen Studien die Testung weiterer BL-Zelllinien mit LEF1-KD erfolgen.

Das unterschiedliche Vermögen, das Matrigel abzubauen, in die CAM einzudringen und zu Einblutungen zu führen, lässt die Hypothese zu, dass die Zellreihen LEF1-unabhängig über unterschiedliche Fähigkeiten verfügen, Proteine der extrazellulären Matrix zu degradieren. Bereits in zahlreichen Arbeiten sind von den über 25 bekannten Metalloproteasen MMP2 und MMP9 als entscheidende Mediatoren verschiedenster Aspekte des Tumorwachstums und der Metastasierung beschrieben worden (Chambers und Matrisian 1997; Egeblad und Werb 2002; Polette et al. 2004; Patel et al. 2009). Speziell im BL ist eine Überexpression von MMP9 beispielsweise durch das EBV latent membrane protein-1 (LMP-1) über den NFKB Signalweg induzierbar (Yoshizaki et al. 1998). Auch Becker et al. (2012) publizier- 
ten eine durch EBV induzierbare Tumor-Stroma-Interaktion zwischen BL und CAM, die schließlich zur Progression des BL beiträgt. Leider war es durch die hohe Eigenaktivität des Serums nicht möglich, die MMPs mittels Zymographie nachzuweisen. Aufgrund der hohen Proliferationsrate der BL-Zellen ist es nicht möglich, serumfreie konditionierte Medien zu gewinnen (Zander und Bemark 2008). Auch innerhalb der Arbeitsgruppe Prof. Dr. Kube wurden serumfreie Versuchsansätze mit BL-Zellen getestet, jedoch war die Anzahl der toten Zellen zu hoch. Zukünftig könnte man die Anregungen aus der Arbeit von Yoshizaki et al. (1998) berücksichtigen, in der mögliche Alternativen beschrieben sind.

Über 12 weitere MMPs sind in Tumorentwicklung und -progression beschrieben (Köhrmann et al. 2009). Daher wäre es auch möglich, dass andere MMPs oder deren Inhibitoren an der Heterogenität der CAM-Lymphome beteiligt sind. 


\section{Zusammenfassung}

Beim Burkitt-Lymphom (BL) handelt es sich um ein hochmalignes, aggressives Non-Hodgkin-Lymphom. Als Kennzeichen dieses Lymphoms gilt die charakteristische MYC-Translokation, die zusammen mit weiteren Mutationen zur Entwicklung eines BL führen kann. Viele Faktoren der BL-Pathogenese sind allerdings bis heute unbekannt und Gegenstand aktueller Forschung.

In der vorliegenden Arbeit sollte der Einfluss eines knockdowns des aberrant im BL exprimierten Transkriptionsfaktors LEF1 in ovo untersucht werden. Dafür wurden viral transduzierte BL-Zellen mit LEF1-KD und entsprechende Kontrollen auf die Chorion-Allantois-Membran des Hühnerembryos appliziert und die daraus hervorgegangenen Tumoren auf morphologische Unterschiede hin analysiert. Parallel wurde das Wachstumsverhalten der parenteralen unveränderten Zelllinien charakterisiert und miteinander verglichen.

In den CAM-Tumoren konnte dabei in zwei von drei BL-Zelllinien nach LEF1-KD eine vessel co-option nachgewiesen werden, die sich in den aberrant LEF1exprimierenden Subklonen nicht findet. Um die ausreichende Versorgung mit Nährstoffen zu gewährleisten, okkupieren die KD-Zellen präexistente Blutgefäße. Die spezielle Orientierung nach Gefäßen kann aber auch in einer geringeren Hypoxietoleranz der KD-Zellen begründet sein. Dementsprechend könnten LEF1Inhibitoren in der zukünftigen Behandlung des BL die Wirksamkeit der bisherigen Polychemotherapie weiter verbessern.

Erschwert wird die einheitliche Bewertung der Daten für BL durch eine von den Invitro-Ergebnissen klar differierende Entwicklung der Zelllinien auf der ChorionAllantois-Membran. Während sich in vitro keine Proliferationsabweichungen erkennen ließen, unterscheiden sie sich in ovo in Bezug auf Tumorgröße, Hämorrhagien, Zelldichte und Tumormorphologie erheblich. Aktuelle Studien stützen hierbei die Vermutung, dass BL z. B. durch verschiedene Mutationsstatus deutlich heterogener sind als bisher angenommen. Gerade in therapierefraktären Situationen sollte daher die individualisierte Therapie des $\mathrm{BL}$ an Bedeutung gewinnen. 


\section{Referenzen}

Ackermann H (Hrsg.): Innere Medizin. AllEx - Alles fürs Examen: Das Kompendium für die 2. ÄP. 2. Auflage; Thieme, Stuttgart 2014

Alberts B, Johnson A, Lewis J, Raff M, Roberts K, Walter P: Molekularbiologie der Zelle. 5. Auflage; John Wiley \& Sons, Weinheim 2011

Ammon J, Karstens J-H, Rathert P: Urologische Onkologie: Radiologische Diagnostik und Strahlentherapie. 2. Auflage; Springer-Verlag, Berlin Heidelberg 2013

Arce L, Yokoyama NN, Waterman ML (2006): Diversity of LEF/TCF action in development and disease. Oncogene 25, 7492-7504

Armelin HA, Armelin MCS, Kelly K, Stewart T, Leder P, Cochran BH, Stiles CD (1984): Functional role for c-myc in mitogenic response to platelet-derived growth factor. Nature $\underline{310}, 655-660$

Barker N, Morin PJ, Clevers H (2000): The Yin-Yang of TCF/beta-catenin signaling. Adv Cancer Res $\underline{77}, 1-24$

Baumgärtel F, Al-Abtah J (Hrsg.): I care-Pflege. (I care Anatomie, Physiologie, Krankheitslehre, Pflege ; [Bd. 3]); Thieme, Stuttgart 2015

Becker J, Covelo-Fernandez A, Bonin F von, Kube D, Wilting J (2012): Specific tumor-stroma interactions of EBV-positive Burkitt's lymphoma cells in the chick chorioallantoic membrane. Vasc Cell $\underline{4}, 3$

Behrens J, von Kries JP, Kühl M, Bruhn L, Wedlich D, Grosschedl R, Birchmeier $W$ (1996): Functional interaction of $\beta$-catenin with the transcription factor LEF-1. Nature 382, 638-642

Berger DP, Engelhardt R, Mertelsmann R: Das Rote Buch: Hämatologie und Internistische Onkologie. 5. Auflage; Hüthig Jehle Rehm, Heidelberg 2013

Bertrand P, Bastard C, Maingonnat C, Jardin F, Maisonneuve C, Courel M-N, Ruminy P, Picquenot J-M, Tilly H (2007): Mapping of MYC breakpoints in 8q24 rearrangements involving non-immunoglobulin partners in B-cell lymphomas. Leukemia 21, 515-523

Bertrand S, Berger R, Philip T, Bernheim A, Bryon P-A, Bertoglio J, Doré J-F, Brunat-Mentigny M, Lenoir GM (1981): Variant translocation in a non endemic case of Burkitt's lymphoma: $t(8 ; 22)$ in an Epstein-Barr virus negative tumour and in a derived cell line. Eur J Cancer $1965 \underline{17}, 577-581$

Bradford MM (1976): A rapid and sensitive method for the quantitation of microgram quantities of protein utilizing the principle of protein-dye binding. Anal Biochem 72, 248-254 
Brunner E, Peter O, Schweizer L, Basler K (1997): Pangolin encodes a Lef-1 homologue that acts downstream of Armadillo to transduce the Wingless signal in Drosophila. Nature $\underline{385}, 829-833$

Buddecke E: Molekulare Medizin: eine systematische Einführung. Hüthig Jehle Rehm, Landsberg 2002

Burkitt D (1958): A sarcoma involving the jaws in african children. $\mathrm{Br} \mathrm{J}$ Surg $\underline{46}$, 218-223

Calender A, Billaud M, Aubry JP, Banchereau J, Vuillaume M, Lenoir GM (1987): Epstein-Barr virus (EBV) induces expression of B-cell activation markers on in vitro infection of EBV-negative B-lymphoma cells. Proc Natl Acad Sci U S A $\underline{84}, 8060-8064$

Chambers AF, Matrisian LM (1997): Changing Views of the Role of Matrix Metalloproteinases in Metastasis. J Natl Cancer Inst $\underline{89}$, 1260-1270

Dalla-Favera R, Bregni M, Erikson J, Patterson D, Gallo RC, Croce CM (1982): Human c-myc onc gene is located on the region of chromosome 8 that is translocated in Burkitt lymphoma cells. Proc Natl Acad Sci U S A $\underline{79}$, 78247827

Damodharan U, Ganesan R, Radhakrishnan UC (2011): Expression of MMP2 and MMP9 (Gelatinases A and B) in Human Colon Cancer Cells. Appl Biochem Biotechnol 165, 1245-1252

Dang CV (2012): MYC on the Path to Cancer. Cell 149, 22-35

Diviné M, Casassus P, Koscielny S, Bosq J, Sebban C, Maignan CL, Stamattoulas A, Dupriez B, Raphaël M, Pico J-L, Ribrag V (2005): Burkitt lymphoma in adults: a prospective study of 72 patients treated with an adapted pediatric LMB protocol. Ann Oncol 16, 1928-1935

Donnem T, Hu J, Ferguson M, Adighibe O, Snell C, Harris AL, Gatter KC, Pezzella F (2013): Vessel co-option in primary human tumors and metastases: an obstacle to effective anti-angiogenic treatment? Cancer Med 2, 427-436

Dürkop H, Foss H-D, Stein H (2011): 2008-WHO-Klassifikation der malignen Lymphome im Jahr 2011. Onkologe 17, 769-788

Egeblad M, Werb Z (2002): New functions for the matrix metalloproteinases in cancer progression. Nat Rev Cancer 2, 161-174

Epstein MA, Achong BG, Barr YM (1964): Virus particles in cultured lymphoblasts from Burkitt's Lymphoma. Lancet 283, 702-703

Fingleton B (2006): Matrix metalloproteinases: roles in cancer and metastasis. Front Biosci 11, 479-491 
Folkman J (1971): Tumor Angiogenesis: Therapeutic Implications. N Engl J Med 285, $1182-1186$

Folkman $\mathrm{J}$ (1990): What is the evidence that tumors are angiogenesis dependent? J Natl Cancer Inst $\underline{\text { 82, }}$ 4-6

He T-C, Sparks AB, Rago C, Hermeking H, Zawel L, Costa LT da, Morin PJ, Vogelstein B, Kinzler KW (1998): Identification of c-MYC as a target of the APC pathway. Science 281, 1509-1512

Holash J, Wiegand S, Yancopoulos G (1999): New model of tumor angiogenesis: dynamic balance between vessel regression and growth mediated by angiopoietins and VEGF. Oncogene 18(38), 5356-62

Holland JD, Klaus A, Garratt AN, Birchmeier W (2013): Wnt signaling in stem and cancer stem cells. Curr Opin Cell Biol 25, 254-264

Huber O, Korn R, McLaughlin J, Ohsugi M, Herrmann BG, Kemler R (1996): Nuclear localization of $\beta$-catenin by interaction with transcription factor LEF-1. Mech Dev $\underline{59}$, 3-10

Hummel M, Bentink S, Berger H, Klapper W, Wessendorf S, Barth TF, Bernd H-W, Cogliatti SB, Dierlamm J, Feller AC, others (2006): A biologic definition of Burkitt's lymphoma from transcriptional and genomic profiling. $\mathrm{N}$ Engl J Med 354, 2419-2430

Jacob A, Prekeris R (2015): The regulation of MMP targeting to invadopodia during cancer metastasis. Front Cell Dev Biol $\underline{3}, 1-9$

Jacob A, Jing J, Lee J, Schedin P, Gilbert SM, Peden AA, Junutula JR, Prekeris R (2013): Rab40b regulates trafficking of MMP2 and MMP9 during invadopodia formation and invasion of breast cancer cells. J Cell Sci $\underline{126}$, 46474658

Jaffe ES (2009): The 2008 WHO classification of lymphomas: implications for clinical practice and translational research. Hematol Am Soc Hematol Educ Program 523-531

Jamieson C, Sharma M, Henderson BR (2014): Targeting the $\beta$-catenin nuclear transport pathway in cancer. Semin Cancer Biol 27, 20-29

Kaiser U, Neubauer A: Maligne Lymphome; in: Lymphknotenerkrankungen im Kopf-Hals-Bereich: Onkologie und Differenzialdiagnostik; hrsg. v. Werner JA; Springer-Verlag, Berlin Heidelberg 2013, 309-323

Kappes JC, Wu X (2001): Safety Considerations in Vector Development. Somat Cell Mol Genet 26, 147-158

Kelly K, Cochran BH, Stiles CD, Leder P (1983): Cell-specific regulation of the Cmyc gene by lymphocyte mitogens and platelet-derived growth factor. Cell $\underline{35}, 603-610$ 
Kersten MJ, Van Gorp J, Pals ST, Boon F, Van Oers MH (1998): Expression of Epstein-Barr virus latent genes and adhesion molecules in AIDS-related non-Hodgkin's lymphomas: correlation with histology and CD4-cell number. Leuk Lymphoma $\underline{30}$, 515-524

Klingenberg M, Becker J, Eberth S, Kube D, Wilting J (2014): The chick chorioallantoic membrane as an in vivo xenograft model for Burkitt lymphoma. BMC Cancer $\underline{14}, 339$

Köhrmann A, Kammerer U, Kapp M, Dietl J, Anacker J (2009): Expression of matrix metalloproteinases (MMPs) in primary human breast cancer and breast cancer cell lines: New findings and review of the literature. BMC Cancer $\underline{9}$, 188

Lennert K: Lymphknoten; in: Lehrbuch der Allgemeinen Pathologie und der Pathologischen Anatomie, 30. Auflage; hrsg. v. Eder M, Gedigk P; SpringerVerlag, Berlin Heidelberg 1977, 392-412

Lennert K, Feller AC: Histopathology of Non-Hodgkin's Lymphomas. 2. Auflage; Springer-Verlag, Berlin Heidelberg 1992

Lennert K, Stein H, Kaiserling E (1975): Cytological and functional criteria for the classification of malignant lymphomata. Br J Cancer Suppl 2, 29-43

Lenoir G, Vuillaume M, Bonnardel C (1985): The use of lymphomatous and lymphoblastoid cell lines in the study of Burkitt's lymphoma. Int Agency Res Cancer Sci Publ 60, 309-318

Li L, Chen B (2012): Therapeutics of Burkitt lymphoma in adults - review. Zhongguo Shi Yan Xue Ye Xue Za Zhi 20, 1289-92

Li Y, Wang L, Zhang M, Melamed J, Liu X, Reiter R, Wei J, Peng Y, Zou X, Pellicer A, et al. (2009): LEF1 in Androgen-Independent Prostate Cancer: Regulation of Androgen Receptor Expression, Prostate Cancer Growth, and Invasion. Cancer Res $\underline{69}$, 3332-3338

Liotta LA, Tryggvason K, Garbisa S, Hart I, Foltz CM, Shafie S (1980): Metastatic potential correlates with enzymatic degradation of basement membrane collagen. Nature 284, 67-68

Love C, Sun Z, Jima D, Li G, Zhang J, Miles R, Richards KL, Dunphy CH, Choi WWL, Srivastava G, et al. (2012): The genetic landscape of mutations in Burkitt lymphoma. Nat Genet $\underline{44}, 1321-1325$

Martin MD, Matrisian LM (2007): The other side of MMPs: Protective roles in tumor progression. Cancer Metastasis Rev $\underline{26}, 717-724$

Matzdorff A, Fritze: Hämatologie; in: Duale Reihe Innere Medizin, 3. überarbeitete Auflage; Thieme, Stuttgart 2012, 1143-1270 
Molyneux EM, Rochford R, Griffin B, Newton R, Jackson G, Menon G, Harrison CJ, Israels T, Bailey S (2012): Burkitt's Iymphoma. Lancet $\underline{379}$, 1234-1244

Mosse C, Weck K: The Molekular Pathology of Burkitt Lymhoma; in: Molecular Pathology of Hematolymphoid Diseases; hrsg. v. Dunphy $\mathrm{CH}$; Springer Science \& Business Media, New York 2010, 277-286

Nie Z, Hu G, Wei G, Cui K, Yamane A, Resch W, Wang R, Green DR, Tessarollo L, Casellas R, et al. (2012): c-Myc Is a Universal Amplifier of Expressed Genes in Lymphocytes and Embryonic Stem Cells. Cell 151, 68-79

Passalidou E, Stewart M, Trivella M, Steers G, Pillai G, Dogan A, Leigh I, Hatton C, Harris A, Gatter K, Pezzella F (2003): Vascular patterns in reactive lymphoid tissue and in non-Hodgkin's lymphoma. Br J Cancer $\underline{88}$, 553-559

Patel P, Shah F, Shukla S, Shah P, Shukla H (2009): Clinical significance of matrix metalloproteinase 2 and 9 in breast cancer. Indian J Cancer $\underline{46}, 194$

Piper W: Innere Medizin. Springer Medizin Verlag, Heidelberg 2007

Polette M, Nawrocki-Raby B, Gilles C, Clavel C, Birembaut P (2004): Tumour invasion and matrix metalloproteinases. Crit Rev Oncol Hematol $\underline{49}, 179-186$

Prinz C: Basiswissen Innere Medizin. Springer Science \& Business Media, Luxemburg 2012

Reya T, O'Riordan M, Okamura R, Devaney E, Willert K, Nusse R, Grosschedl R (2000): Wnt signaling regulates $B$ lymphocyte proliferation through a LEF-1 dependent mechanism. Immunity $\underline{13}, 15-24$

Richter J, Schlesner M, Hoffmann S, Kreuz M, Leich E, Burkhardt B, Rosolowski M, Ammerpohl O, Wagner R, Bernhart S, et al. (2012): Recurrent mutation of the ID3 gene in Burkitt lymphoma identified by integrated genome, exome and transcriptome sequencing. Nat Genet 44, 1316-1320

Riese J, Yu X, Munnerlyn A, Eresh S, Hsu S-C, Grosschedl R, Bienz M (1997): LEF-1, a Nuclear Factor Coordinating Signaling Inputs from wingless and decapentaplegic. Cell $\underline{88}, 777-787$

Robert Koch-Institut: Krebs in Deutschland 2009/2010. 9. Ausgabe; Robert KochInstitut, Berlin 2013

Roskelley CD, Bissell MJ (1995): Dynamic reciprocity revisited: a continuous, bidirectional flow of information between cells and the extracellular matrix regulates mammary epithelial cell function. Biochem Cell Biol $\underline{73}$, 391-397

Roskelley CD, Srebrow A, Bissell MJ (1995): A hierarchy of ECM-mediated signalling regulates tissue-specific gene expression. Curr Opin Cell Biol $\underline{7}, 736-$ 747 
Scarpa E-S, Ninfali P (2015): Phytochemicals as Innovative Therapeutic Tools against Cancer Stem Cells. Int J Mol Sci 16, 15727-15742

Schmitz R, Young RM, Ceribelli M, Jhavar S, Xiao W, Zhang M, Wright G, Shaffer AL, Hodson DJ, Buras E, et al. (2012): Burkitt Lymphoma Pathogenesis and Therapeutic Targets from Structural and Functional Genomics. Nature $\underline{490}, 116$

Schmitz R, Ceribelli M, Pittaluga S, Wright G, Staudt LM (2014): Oncogenic Mechanisms in Burkitt Lymphoma. Cold Spring Harb Perspect Med 4, a014282

Sedlacek H-H: Onkologie - die Tumorerkrankungen des Menschen: Entstehung, Abwehr und Behandlungsmöglichkeiten. Walter de Gruyter, Berlin 2013

Shang D, Bi R, Han T, Wang D, Tian Y, Liu Y (2014): Expression and Proliferation-Promoting Role of Lymphoid Enhancer-Binding Factor 1 in Human Clear Cell Renal Carcinoma. Cancer Invest 32, 368-374

Shelton DN, Fornalik H, Neff T, Park SY, Bender D, DeGeest K, Liu X, Xie W, Meyerholz DK, Engelhardt JF, Goodheart MJ (2012): The Role of LEF1 in Endometrial Gland Formation and Carcinogenesis. PLoS ONE ㄱ, e40312

Shweiki D, Neeman M, Itin A, Keshet E (1995): Induction of vascular endothelial growth factor expression by hypoxia and by glucose deficiency in multicell spheroids: implications for tumor angiogenesis. Proc Natl Acad Sci U S A $\underline{92}, 768$

Stein H: WHO-Klassifkation hämatologischer Neoplasien mit Schwerpunkt indolente Lymphome; in: Indolente Lymphome: Pathophysiologie, Prognosefaktoren und aktuelle Therapieempfehlungen; hrsg. v. Buske C, Mahlmann S; Deutscher Ärzteverlag, Köln 2011, 1-22

Steinke FC, Xue H-H (2014): From inception to output, Tcf1 and Lef1 safeguard development of $T$ cells and innate immune cells. Immunol Res $\underline{59}, 45-55$

Sternlicht MD, Werb Z (2001): How Matrix Metalloproteinases regulate Cell Behavior. Annu Rev Cell Dev Biol 17, 463-516

Thermo Fisher Scientific Inc (2013): Thermo Scientific GIPZ Lentiviral shRNA Technical Manual.

Tiemann M, Trümper L (2001): Pathologie, Biologie und Klassifikation maligner Non-Hodgkin-Lymphome. Onkologe $\underline{7}$, 940-959

Travis A, Amsterdam A, Belanger C, Grosschedl R (1991): LEF-1, a gene encoding a lymphoid-specific protein with an HMG domain, regulates T-cell receptor alpha enhancer function. Genes Dev $\underline{5}, 880-894$ 
Vockerodt M, Tesch H, Kube D (2001): Epstein-Barr virus latent membrane protein-1 activates CD25 expression in lymphoma cells involving the NFkappaB pathway. Genes Immun 2, 433-441

Walther N, Ulrich A, Vockerodt M, von Bonin F, Klapper W, Meyer K, Eberth S, Pukrop T, Spang R, Trümper L, Kube D (2013): Aberrant lymphocyte enhancer-binding factor 1 expression is characteristic for sporadic Burkitt's lymphoma. Am J Pathol 182, 1092-1098

Wang W-J, Yao Y, Jiang L-L, Hu T-H, Ma J-Q, Liao Z-J, Yao J-T, Li D-F, Wang S$\mathrm{H}$, Nan K-J (2013): Knockdown of lymphoid enhancer factor 1 inhibits colon cancer progression in vitro and in vivo. PloS One $\underline{8}$, e76596

Waterman ML (2004): Lymphoid Enhancer Factor/T Cell Factor Expression in Colorectal Cancer. Cancer Metastasis Rev 23, 41-52

Wilming P: Untersuchungen zur Angiogenese des Burkitt-Lymphoms unter besonderer Berücksichtigung des Lymphocyte Enhancer-Binding Factor-1. Med. Diss. Göttingen 2017

Woessner JF (1991): Matrix metalloproteinases and their inhibitors in connective tissue remodeling. FASEB $\mathrm{J} \underline{5}, 2145-2154$

Yoshizaki T, Sato H, Furukawa M, Pagano JS (1998): The expression of matrix metalloproteinase 9 is enhanced by Epstein-Barr virus latent membrane protein 1. Proc Natl Acad Sci U S A 95, 3621-3626

Zander L, Bemark M (2008): Identification of genes deregulated during serum-free medium adaptation of a Burkitt's lymphoma cell line. Cell Prolif $\underline{41}, 136-155$

Zech L, Haglund U, Nilsson K, Klein G (1976): Characteristic chromosomal abnormalities in biopsies and lymphoid-cell lines from patients with burkitt and non-burkitt lymphomas. Int J Cancer $\underline{17}$, 47-56 


\section{Danksagung}

An dieser Stelle möchte ich mich bei all denjenigen bedanken, die mich während der Anfertigung dieser Doktorarbeit unterstützt haben. Insbesondere gilt mein Dank den folgenden Personen, ohne deren Hilfe diese Dissertation niemals zustande gekommen wäre:

Mein Dank gilt zunächst meinem Doktorvater, Herrn Prof. Dr. Dieter Kube, für die Möglichkeit und das Vertrauen, diese Arbeit in seiner Arbeitsgruppe durchzuführen. Insbesondere der konstruktive Austausch in zahlreichen Gesprächen und das mühevolle Korrekturlesen waren eine große Hilfe für mich.

Bei Prof. Dr. Trümper möchte ich mich dafür bedanken, dass ich in seiner Abteilung promovieren durfte.

Ein besonderer Dank gilt meiner Betreuerin, Dr. Sonja Ebert, die mich täglich bei der Versuchsplanung und -durchführung unterstützte, stets ein offenes Ohr für meine Fragen hatte, mich immer ermutigte und mir insgesamt beim Verfassen dieser Arbeit eine große Hilfe war.

Frau Dr. Franziska Linke danke ich für die wissenschaftliche Unterstützung und den humorvollen Umgang. Herzlichen Dank auch an Pia Wilming für die tolle Einarbeitung und auch spätere Hilfe in vielen Belangen. Frederike von Bonin möchte ich für die freundliche Mithilfe an den zahlreichen CAM-Assays danken, ebenso Susanne Hengst für Hilfestellungen im Labor.

Zuletzt geht mein Dank an die Mitarbeiter des Zentrums für Anatomie Göttingen, insbesondere an Prof. Dr. Wilting, Berti Manshausen und Sonja Schwoch für die freundliche technische Unterstützung in der Durchführung meiner Experimente. 